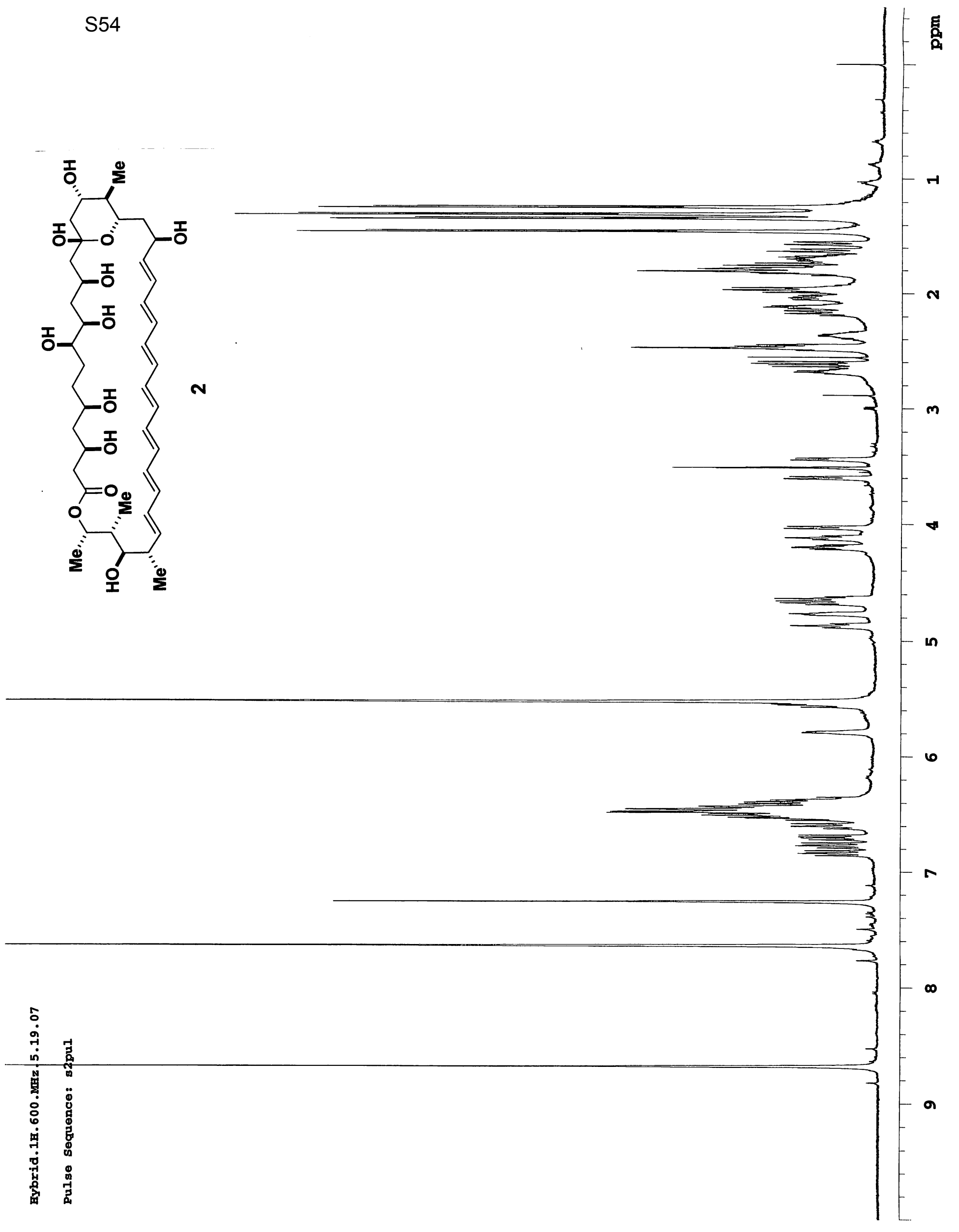




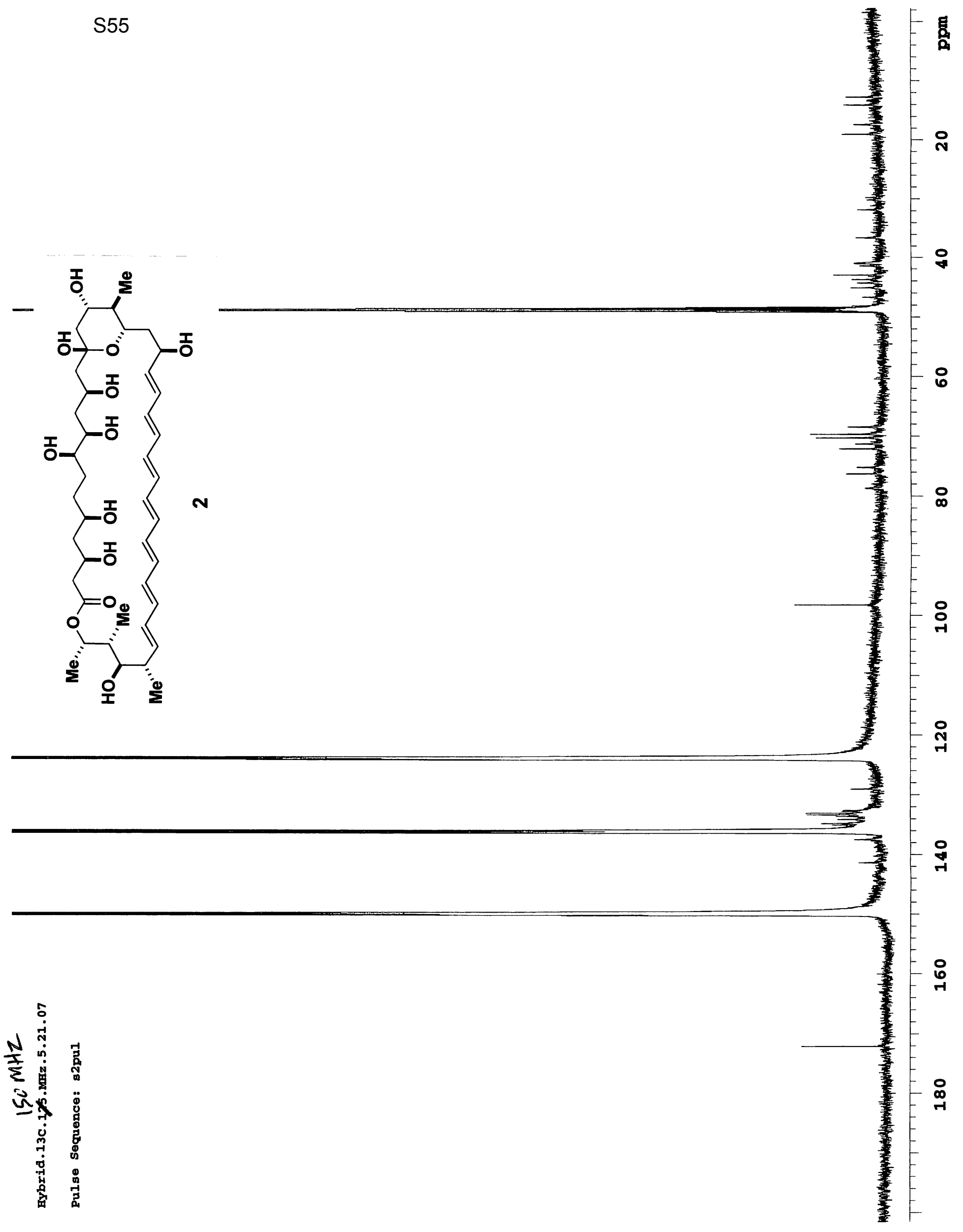




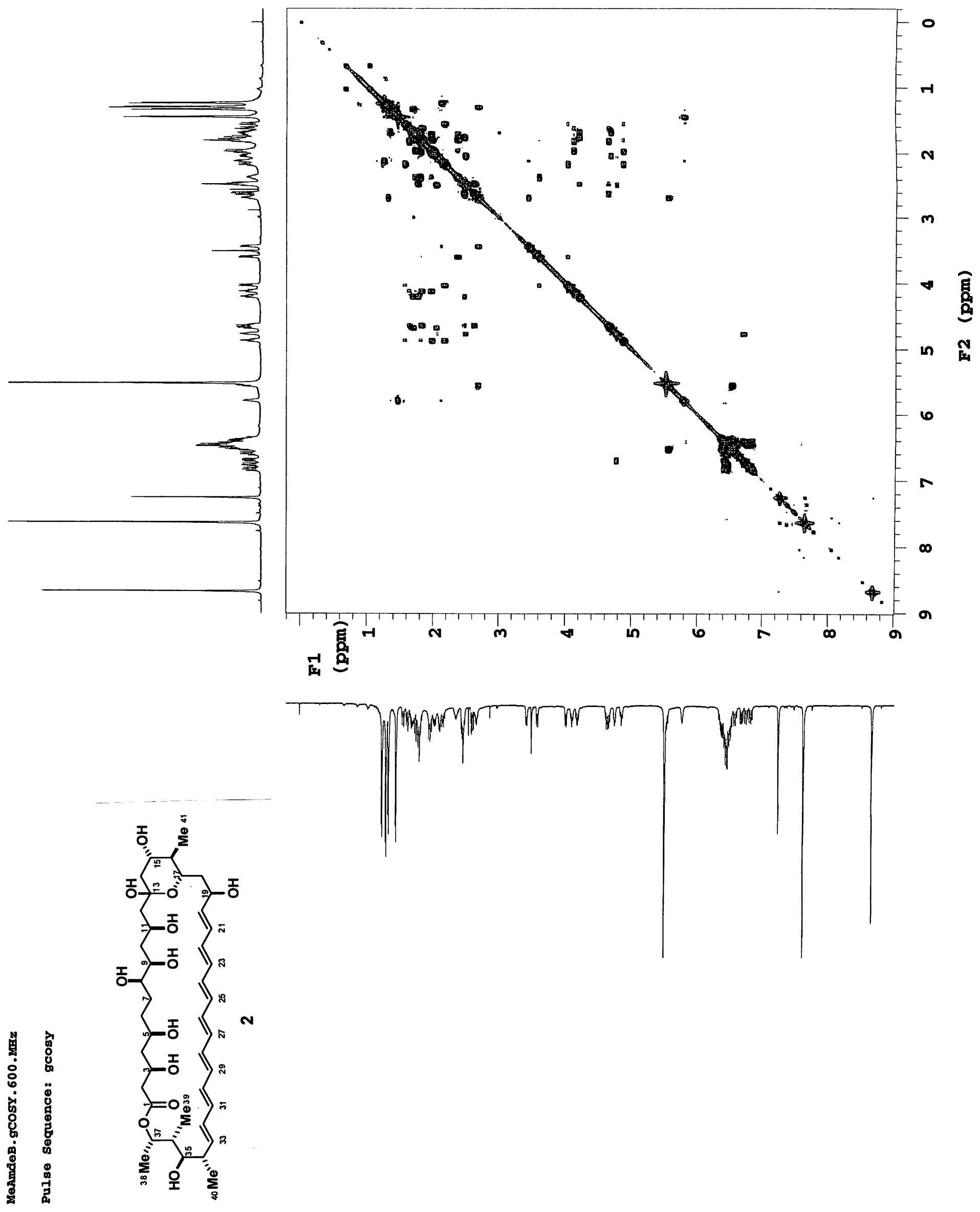


S57
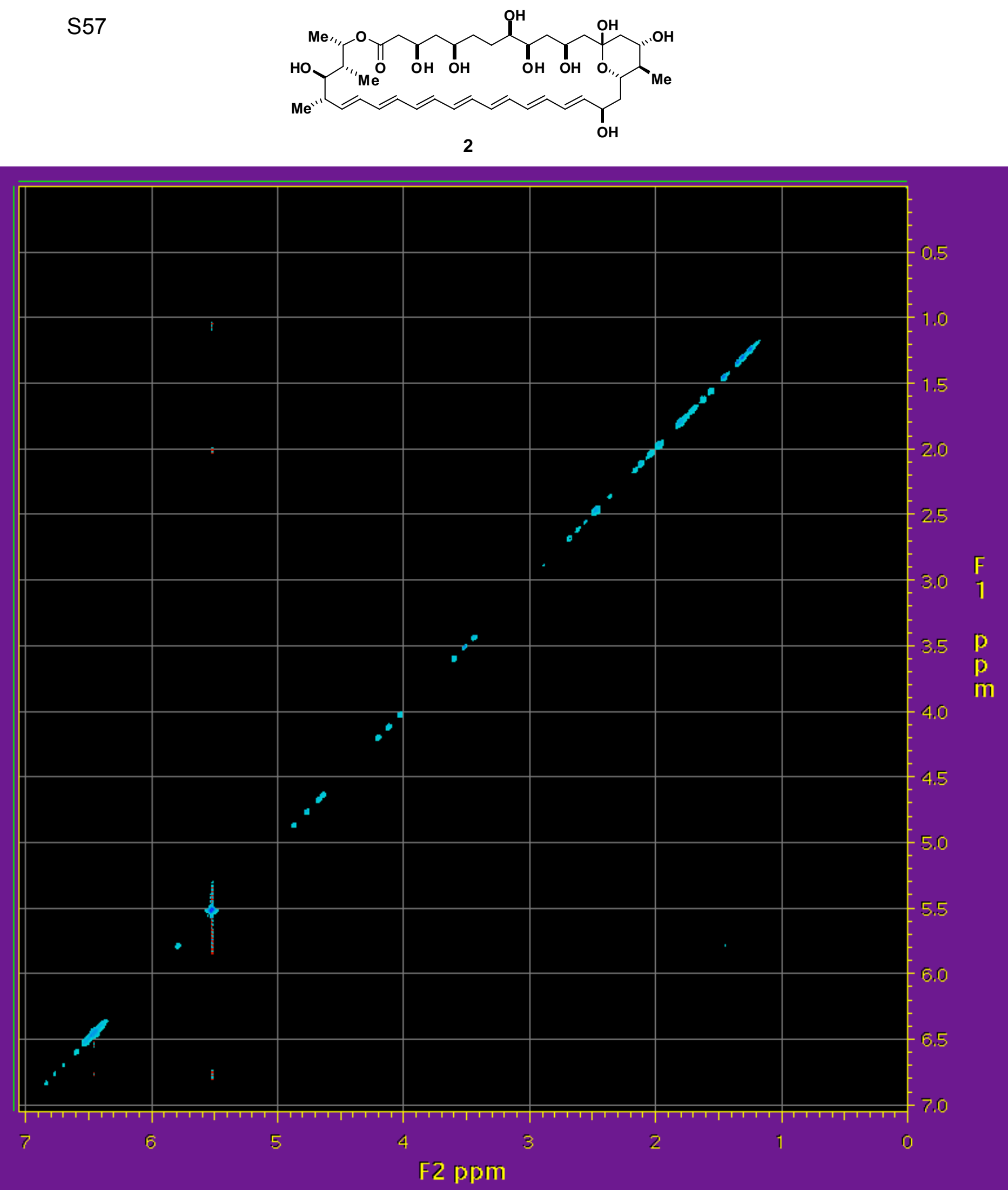

$500 \mathrm{MHz}$ diagonal COSYPS spectrum of 2 
S58

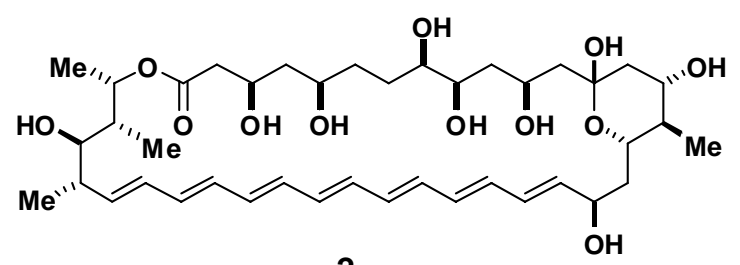

2

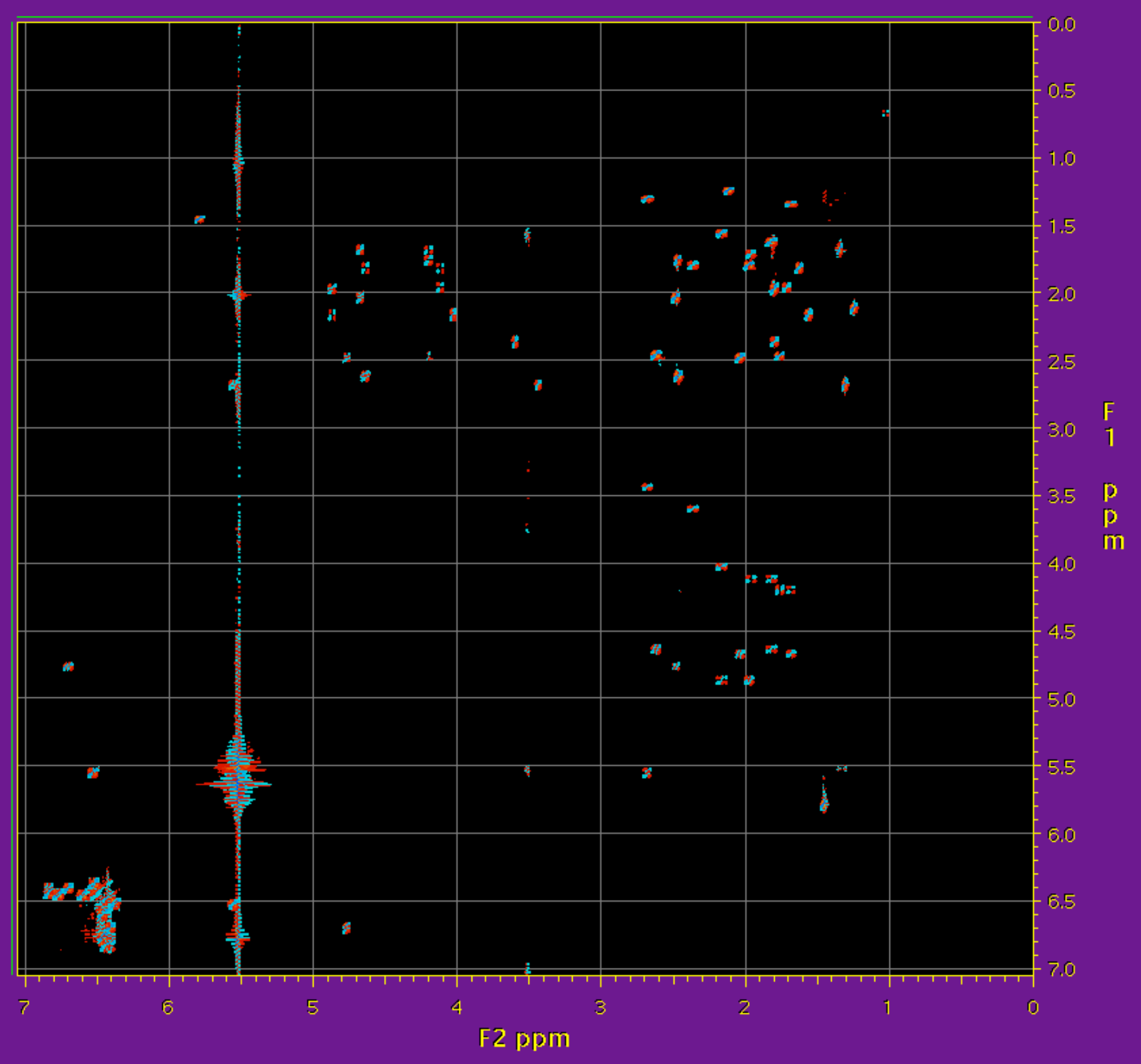

$500 \mathrm{MHz}$ COSYPS diagonal-suppressed spectrum of 2 
S59
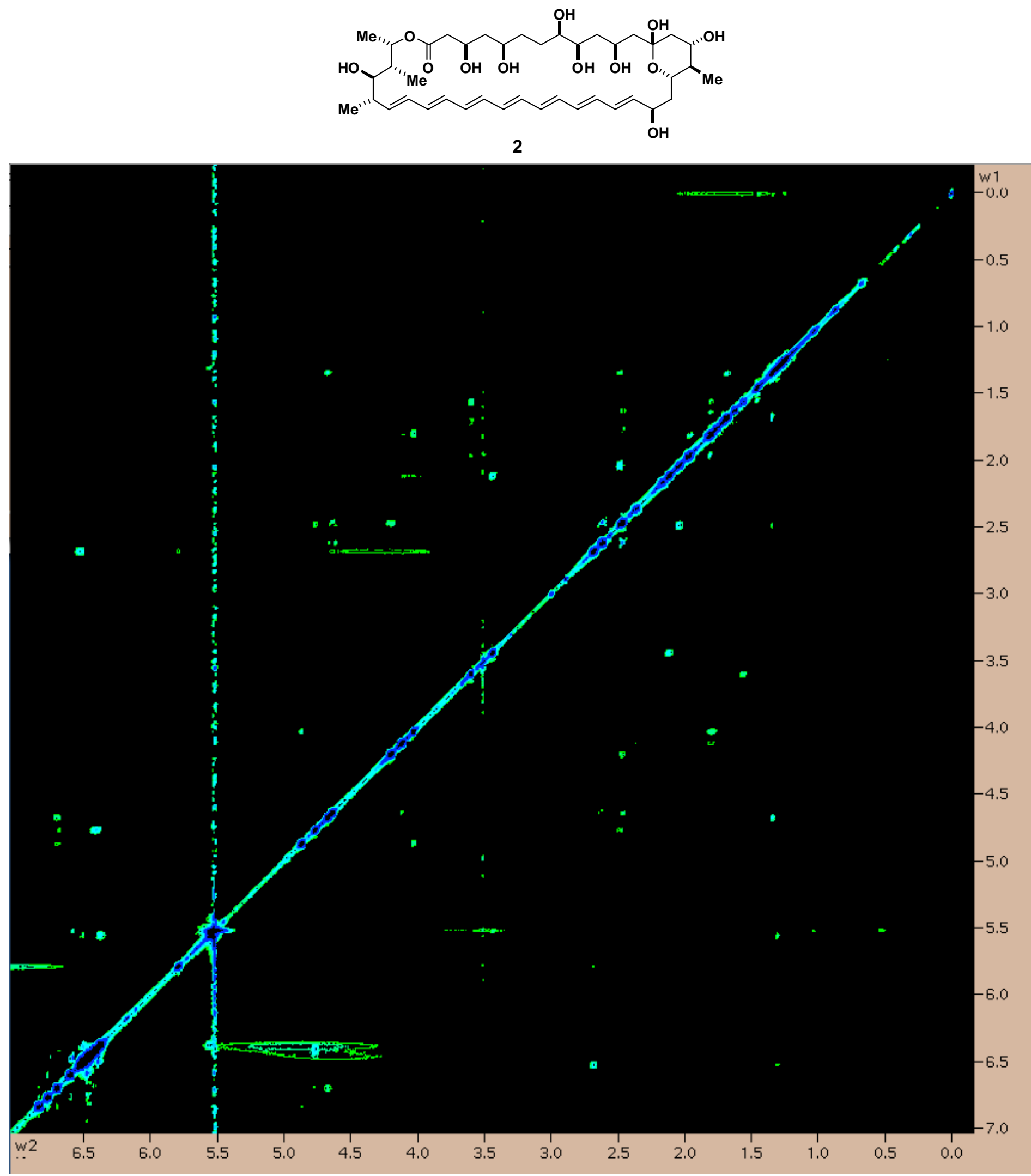

600 MHz NOESY Spectrum of 2 


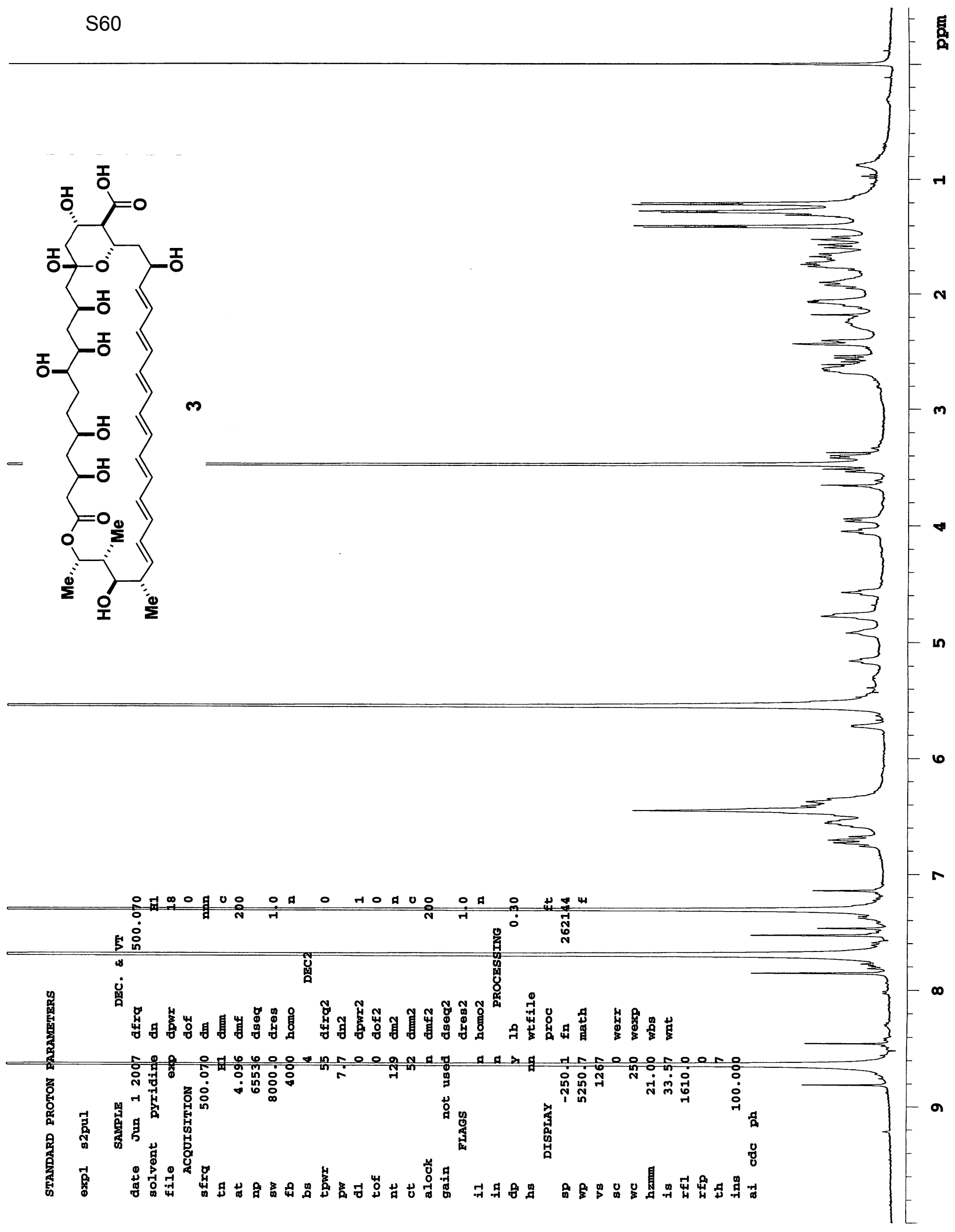



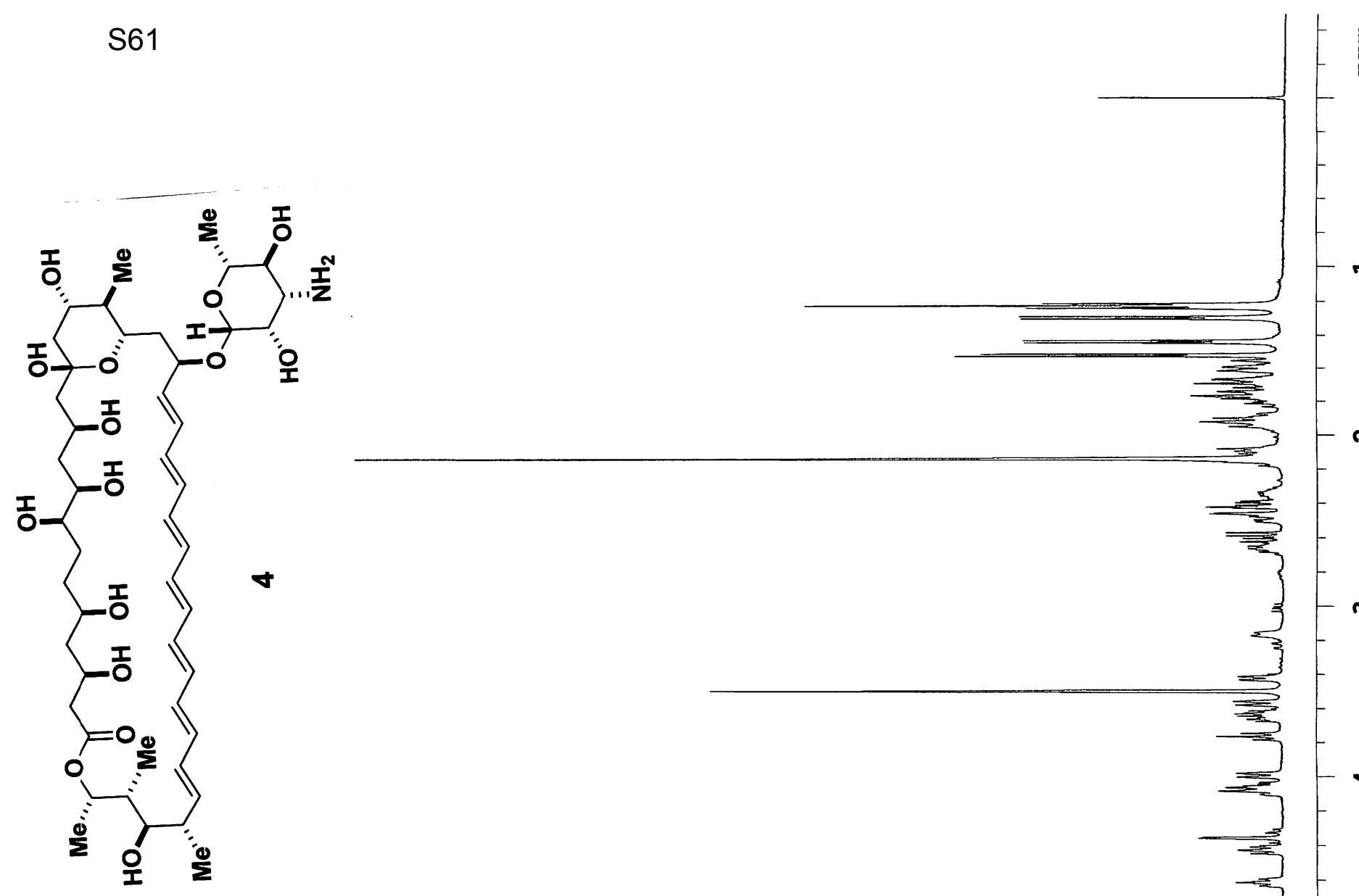

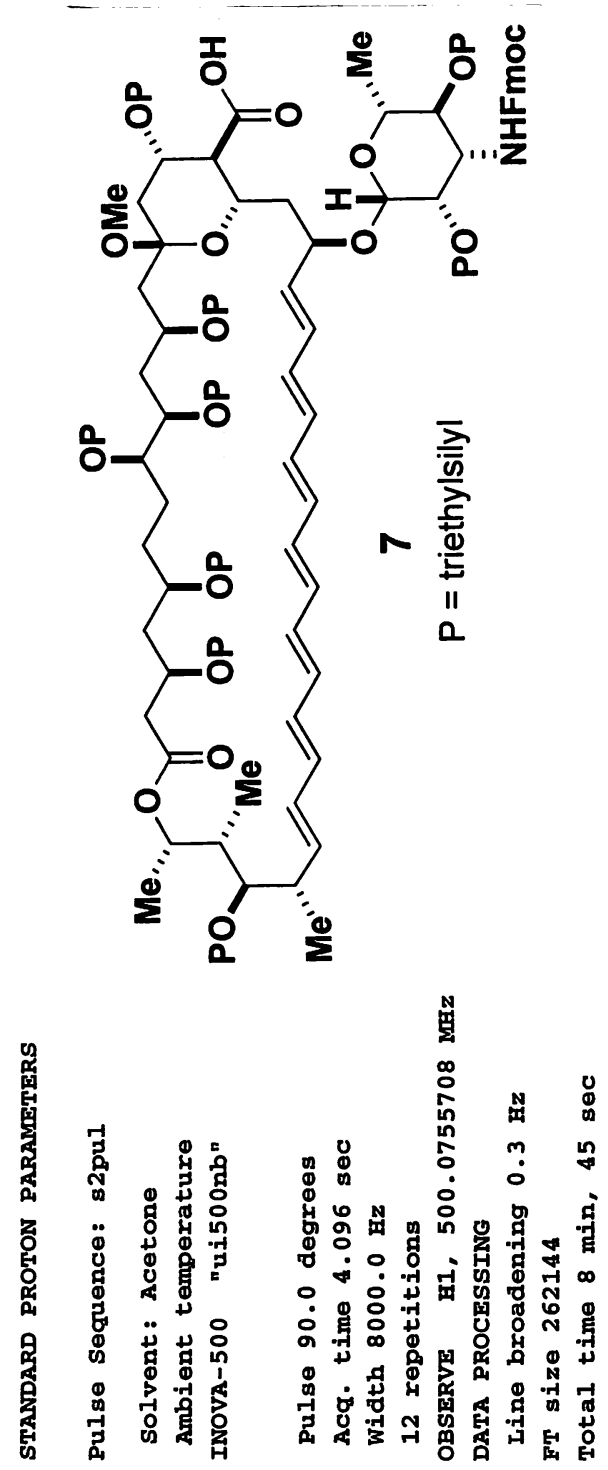

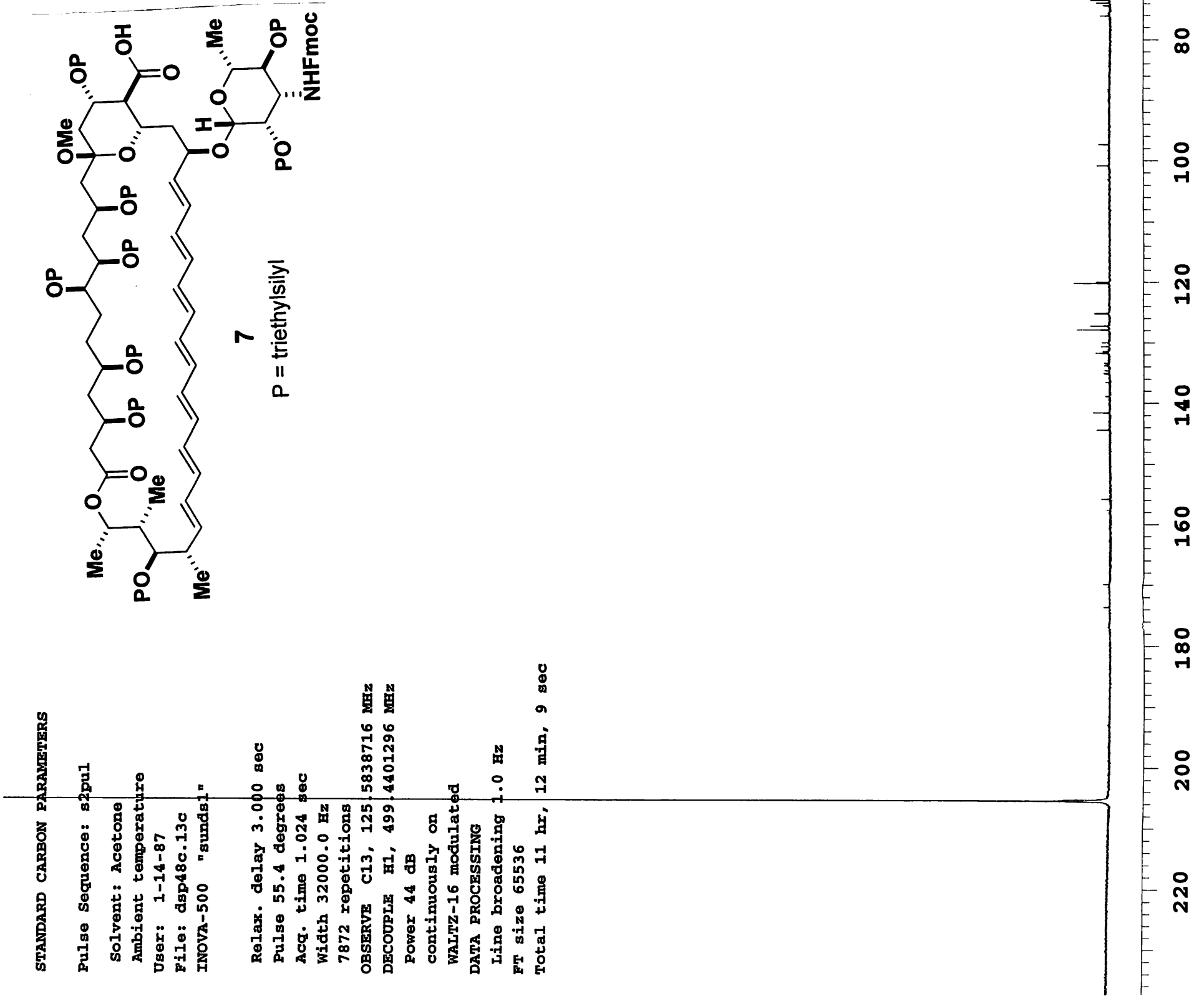

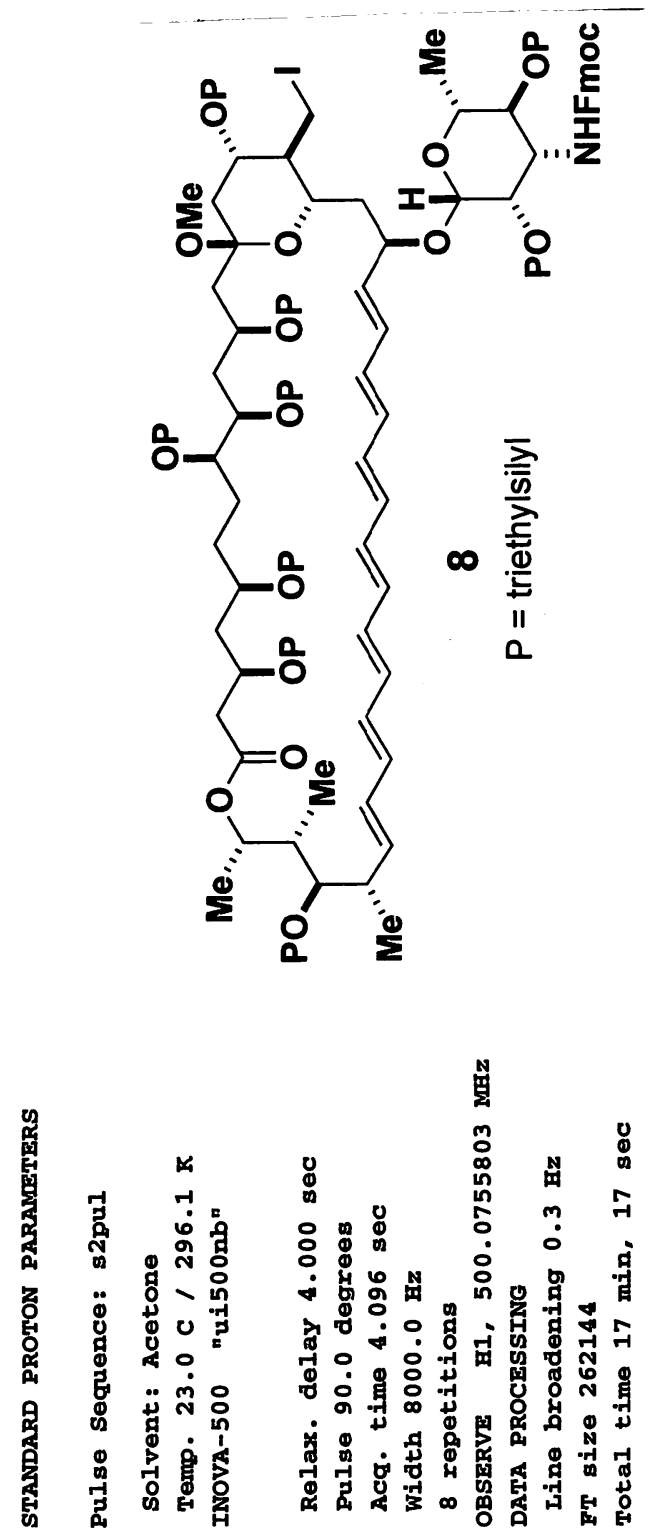

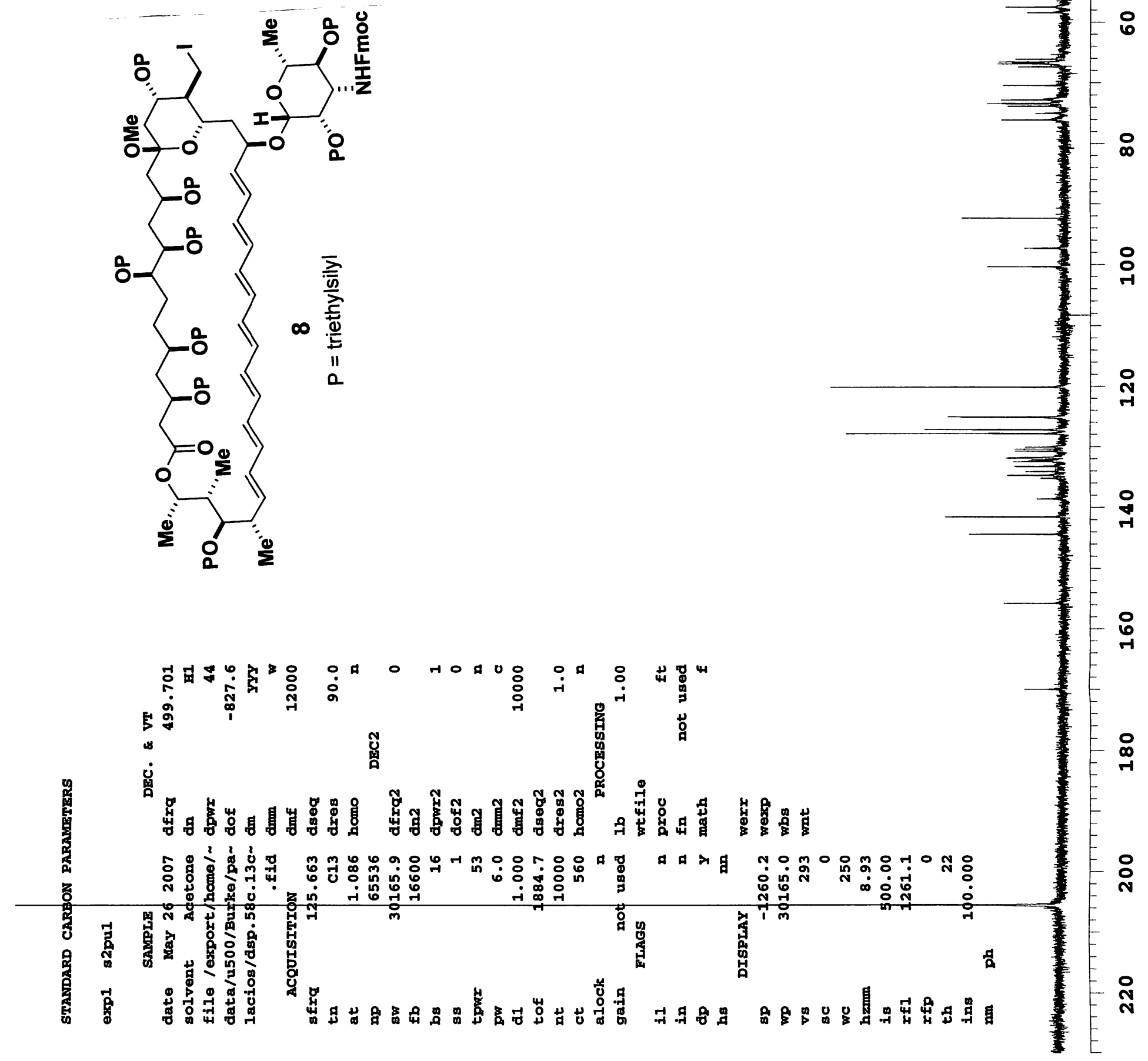

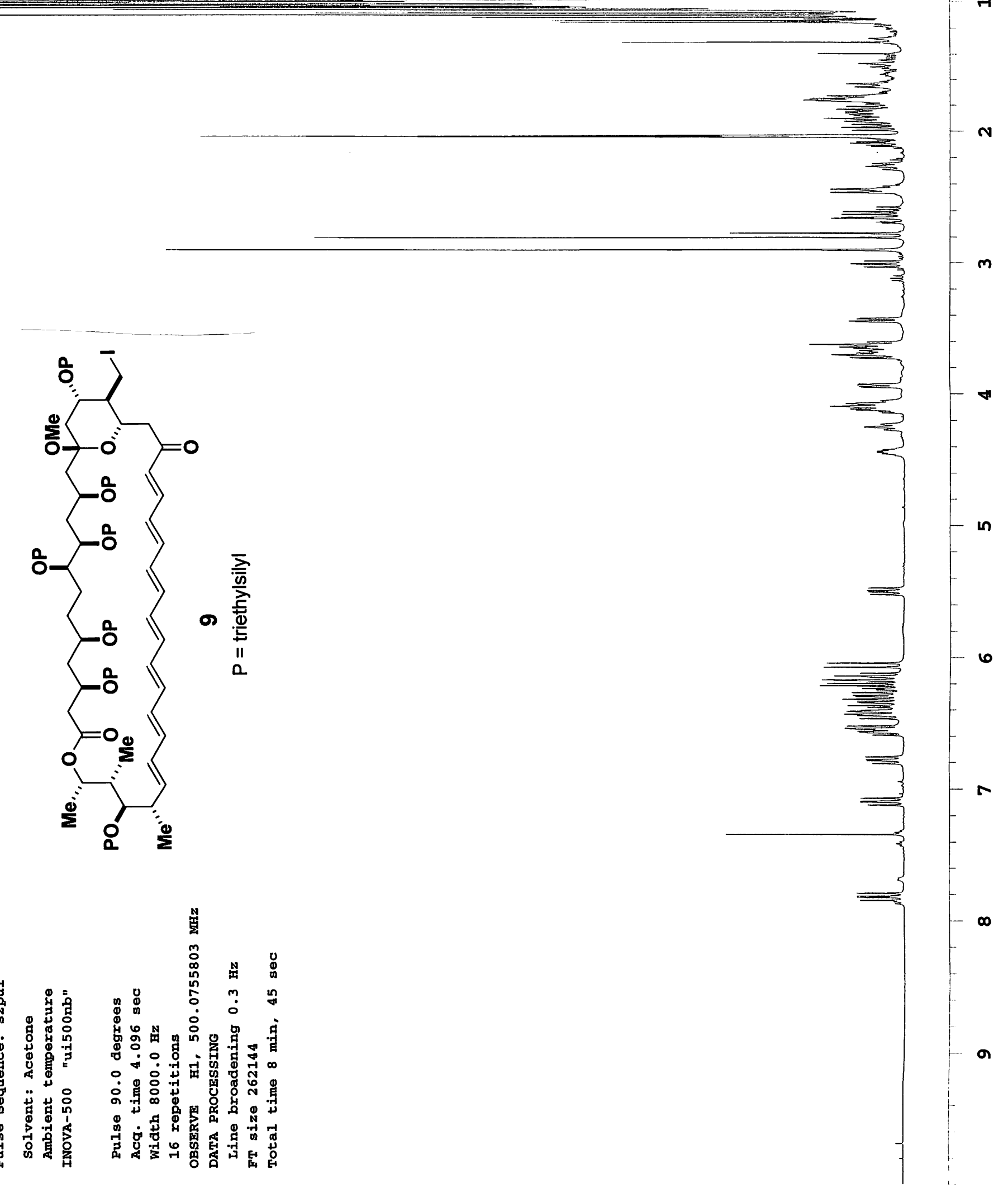

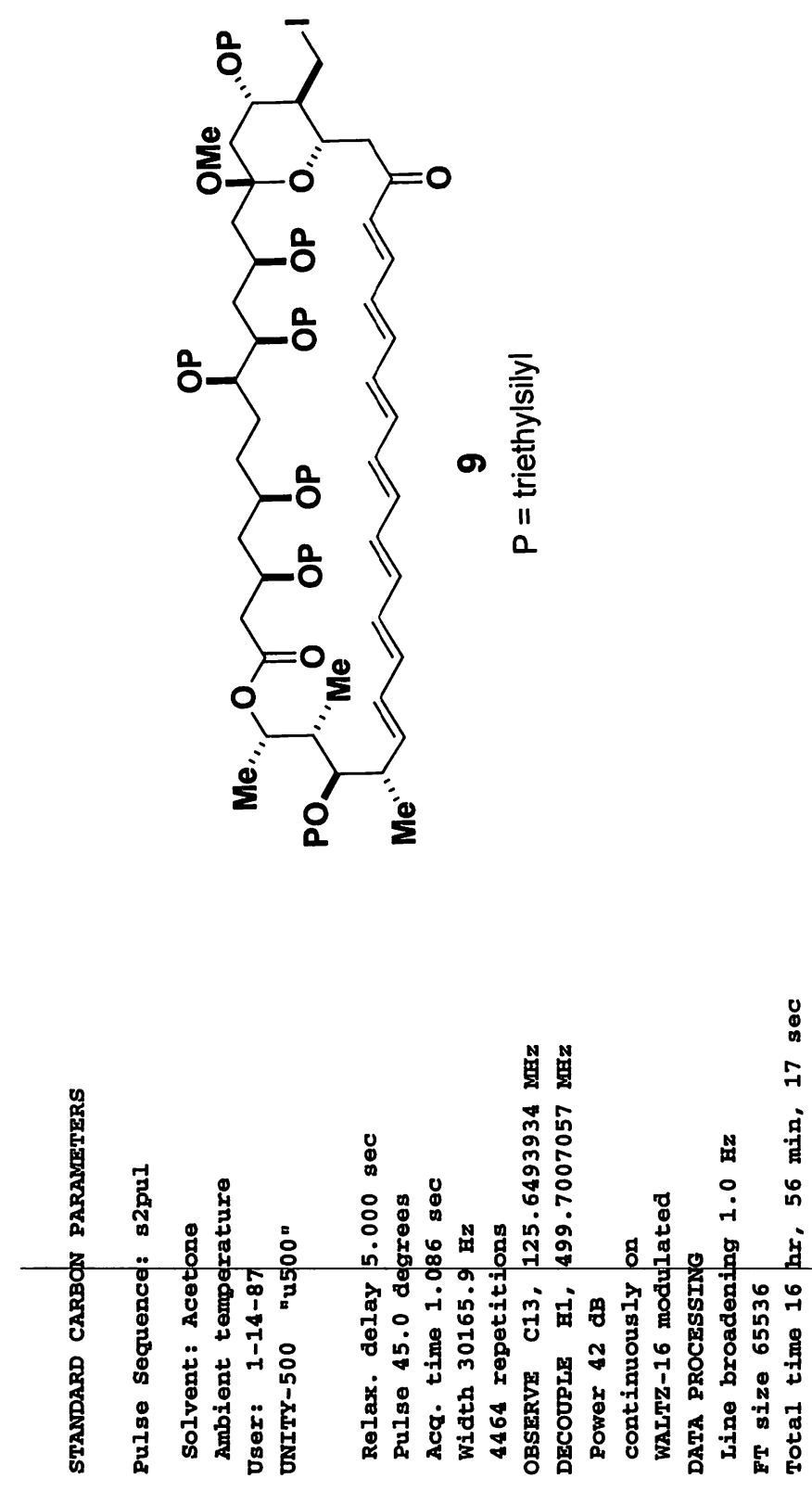

竞 

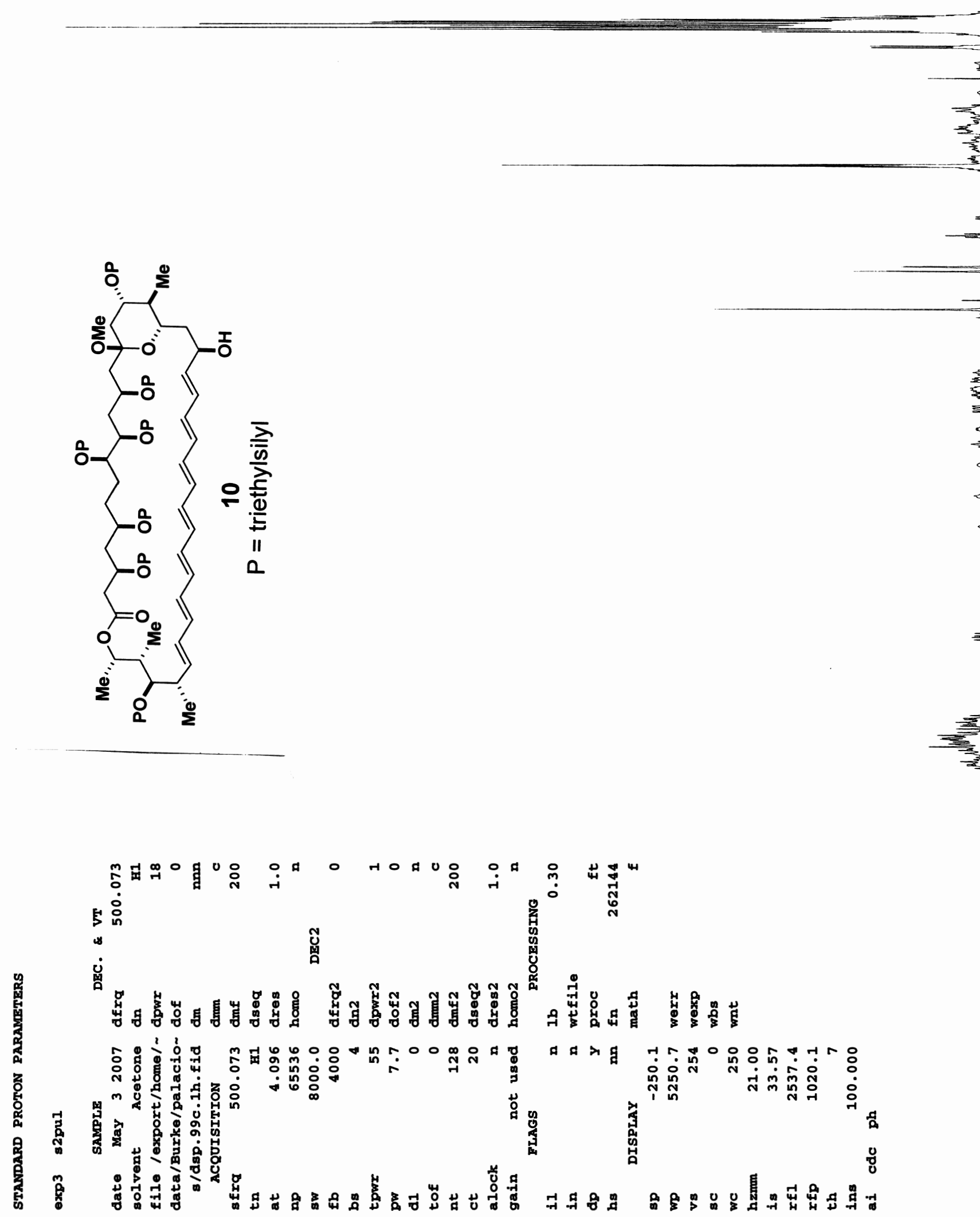


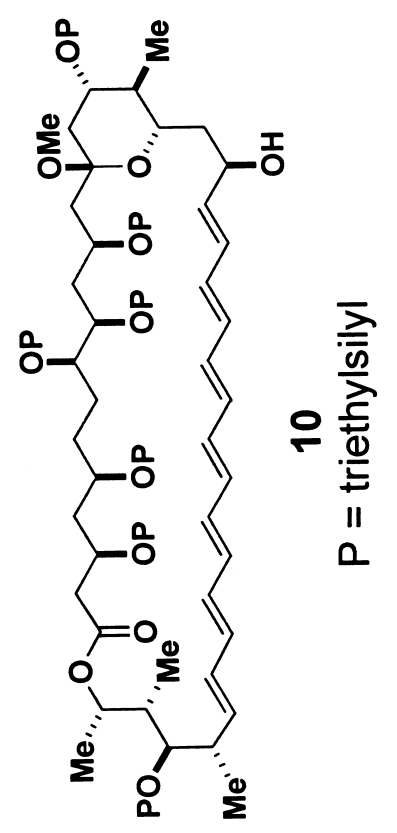

ฉ్

o

i

o

0
0

$\underset{\infty}{\infty}$

욱

ํㅗㄱ

감

0
0
-1

0
$\infty$
-1

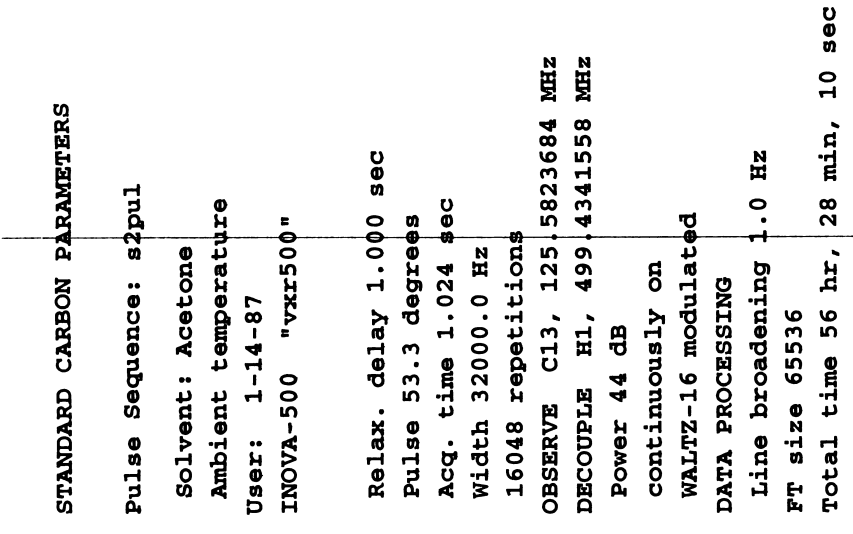

옹

i 


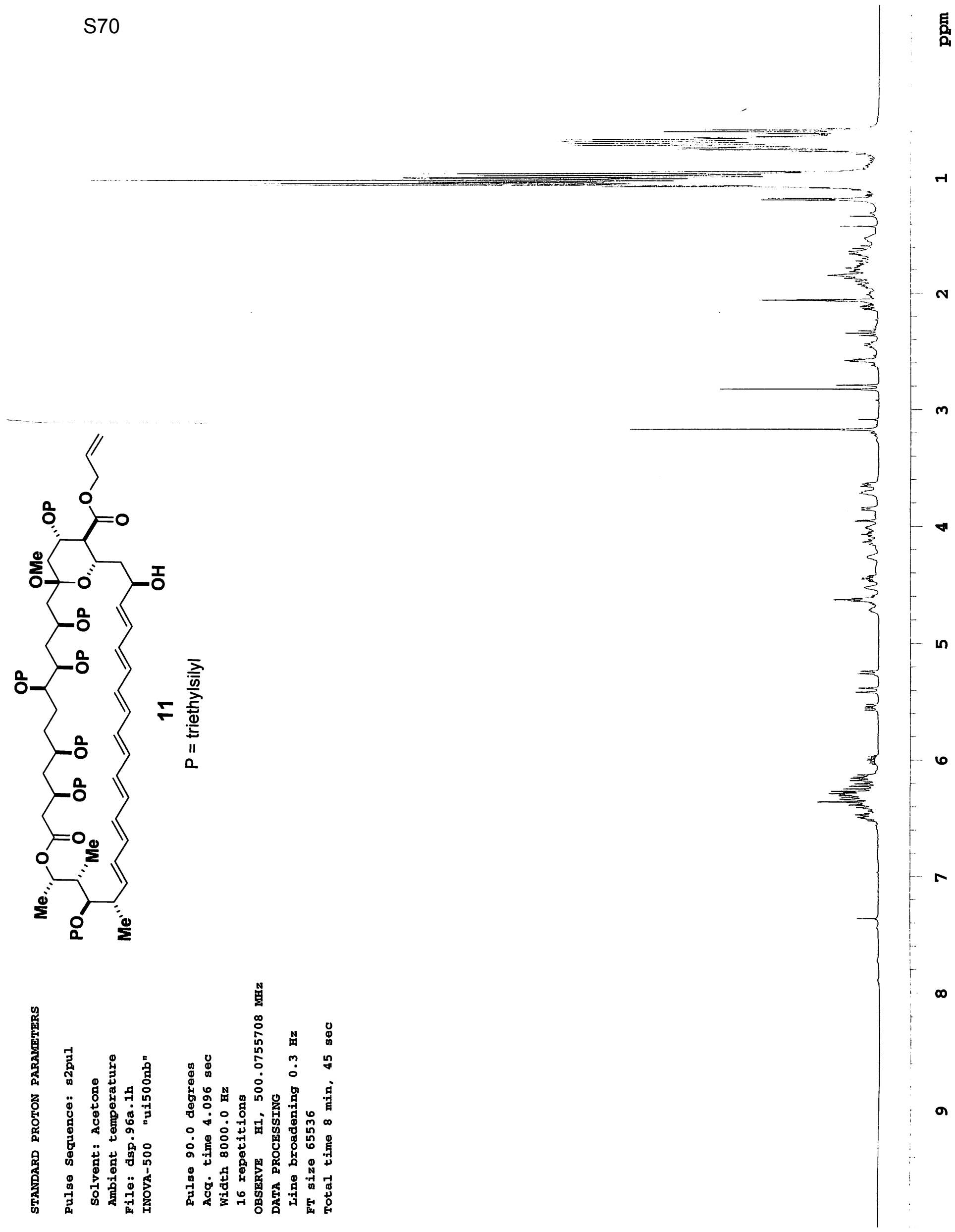




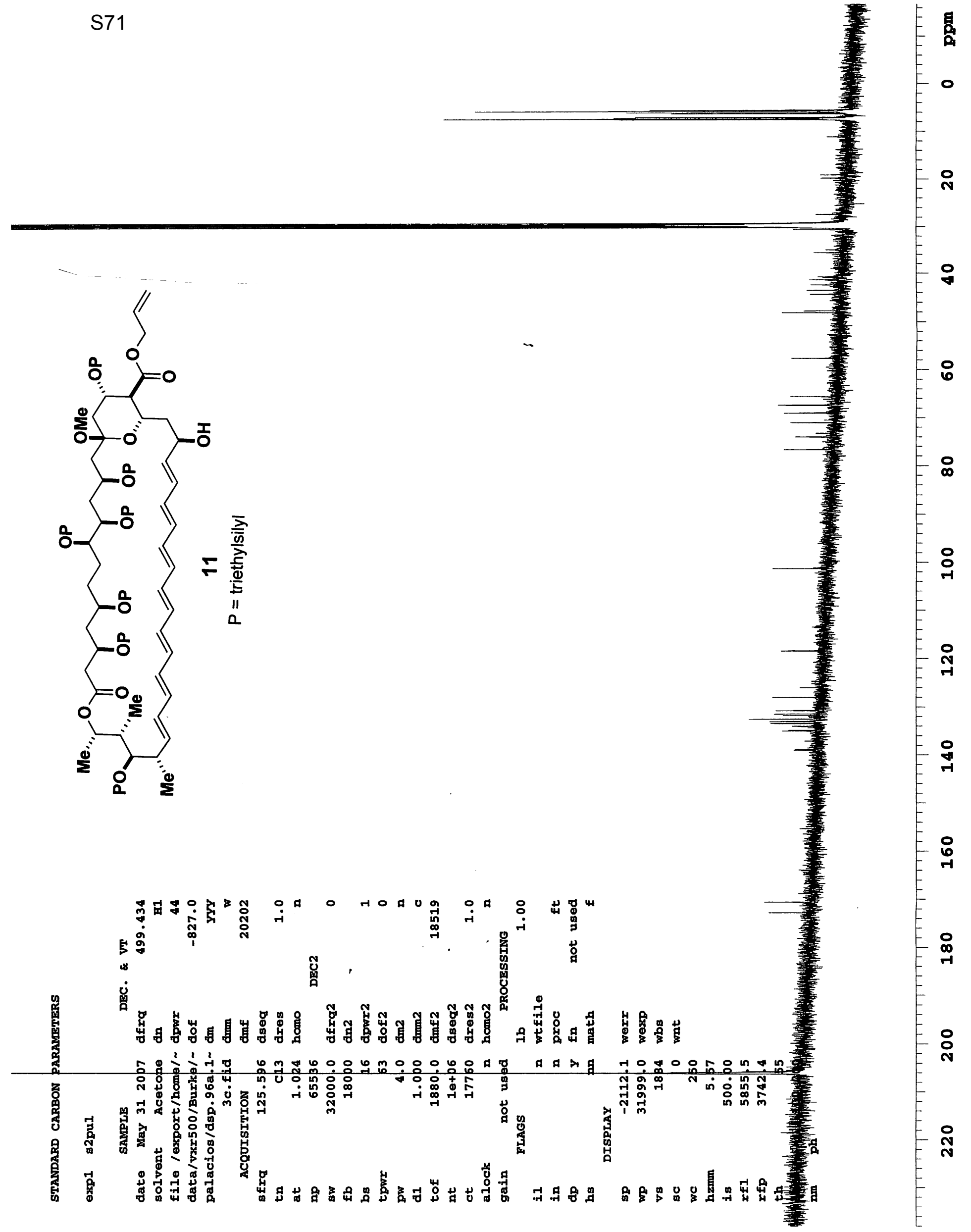




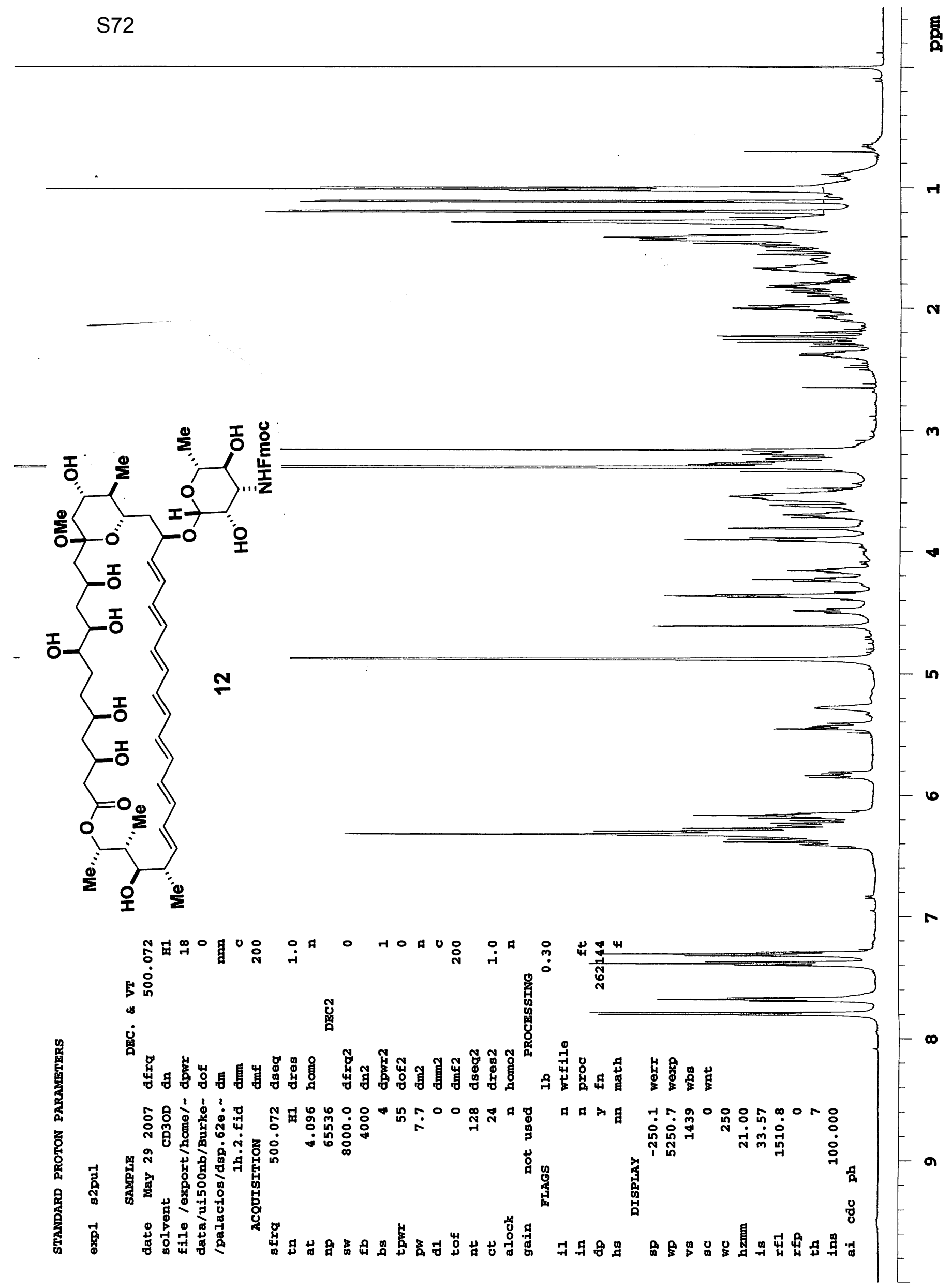



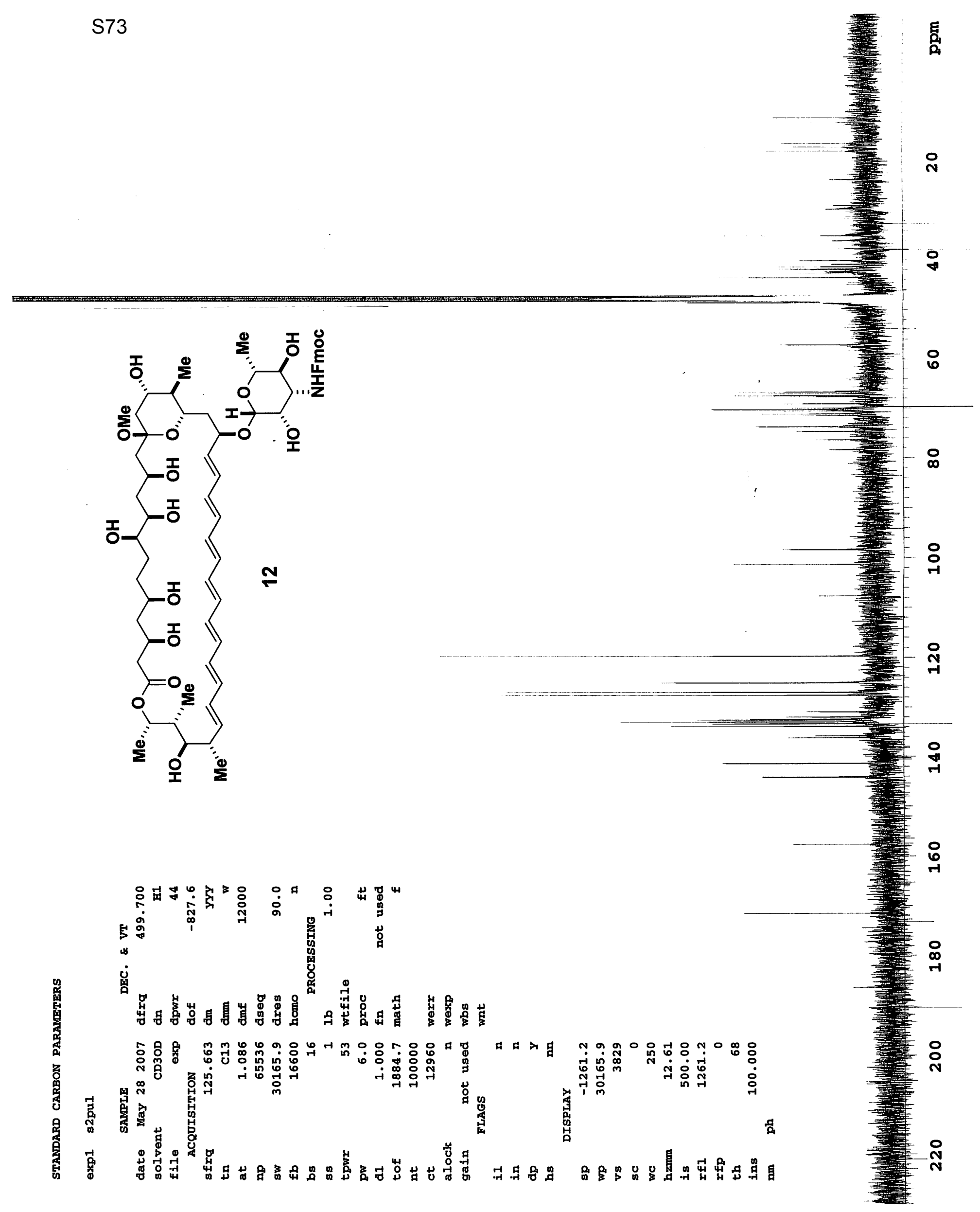


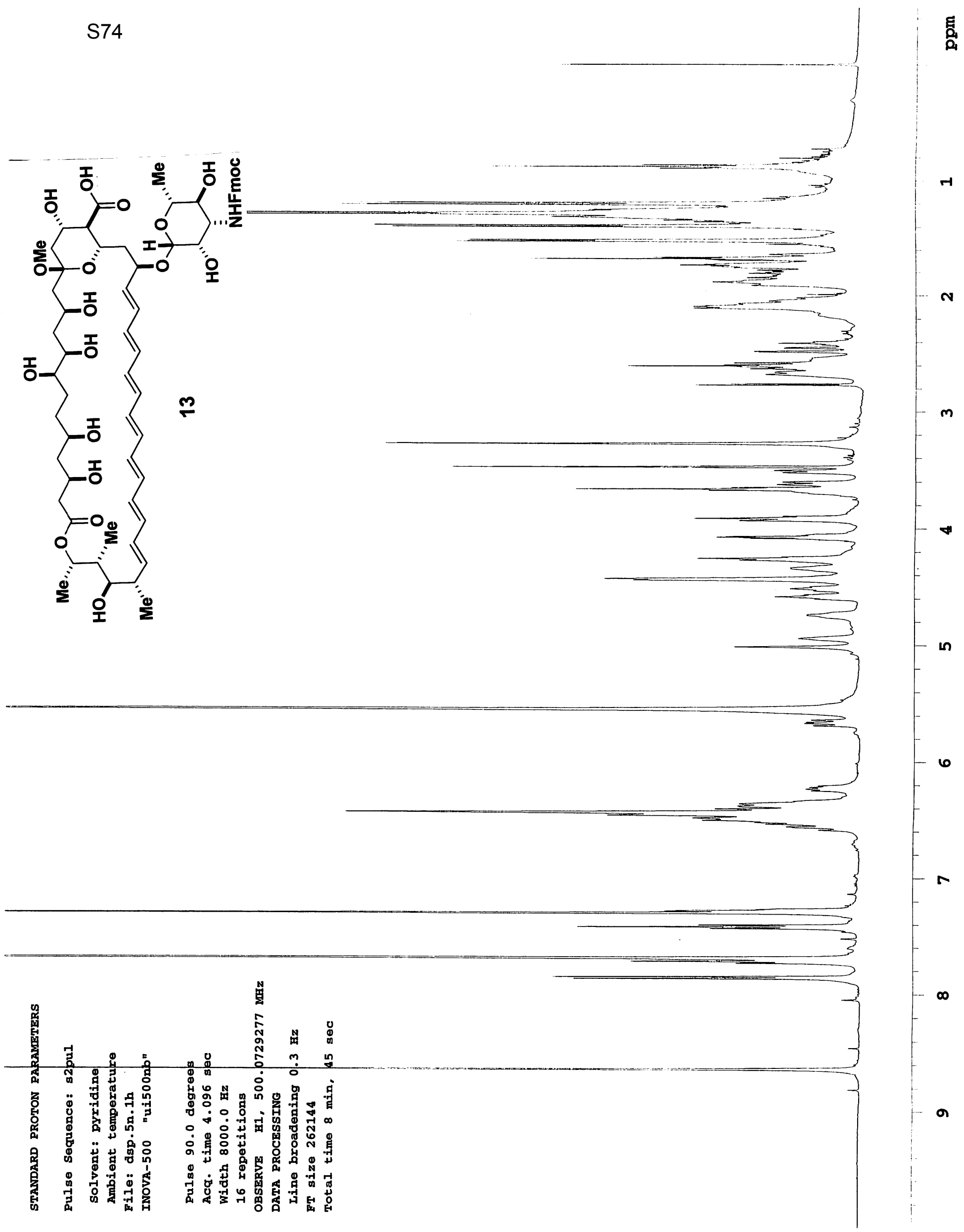




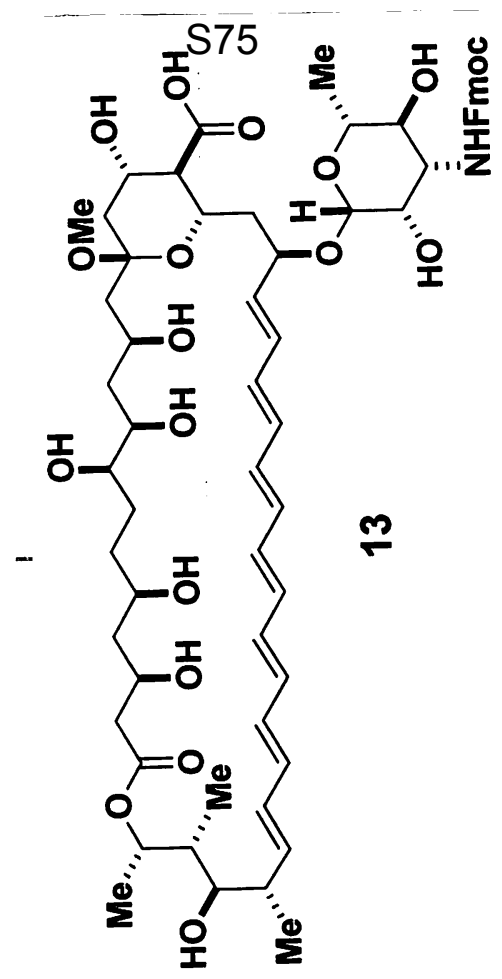



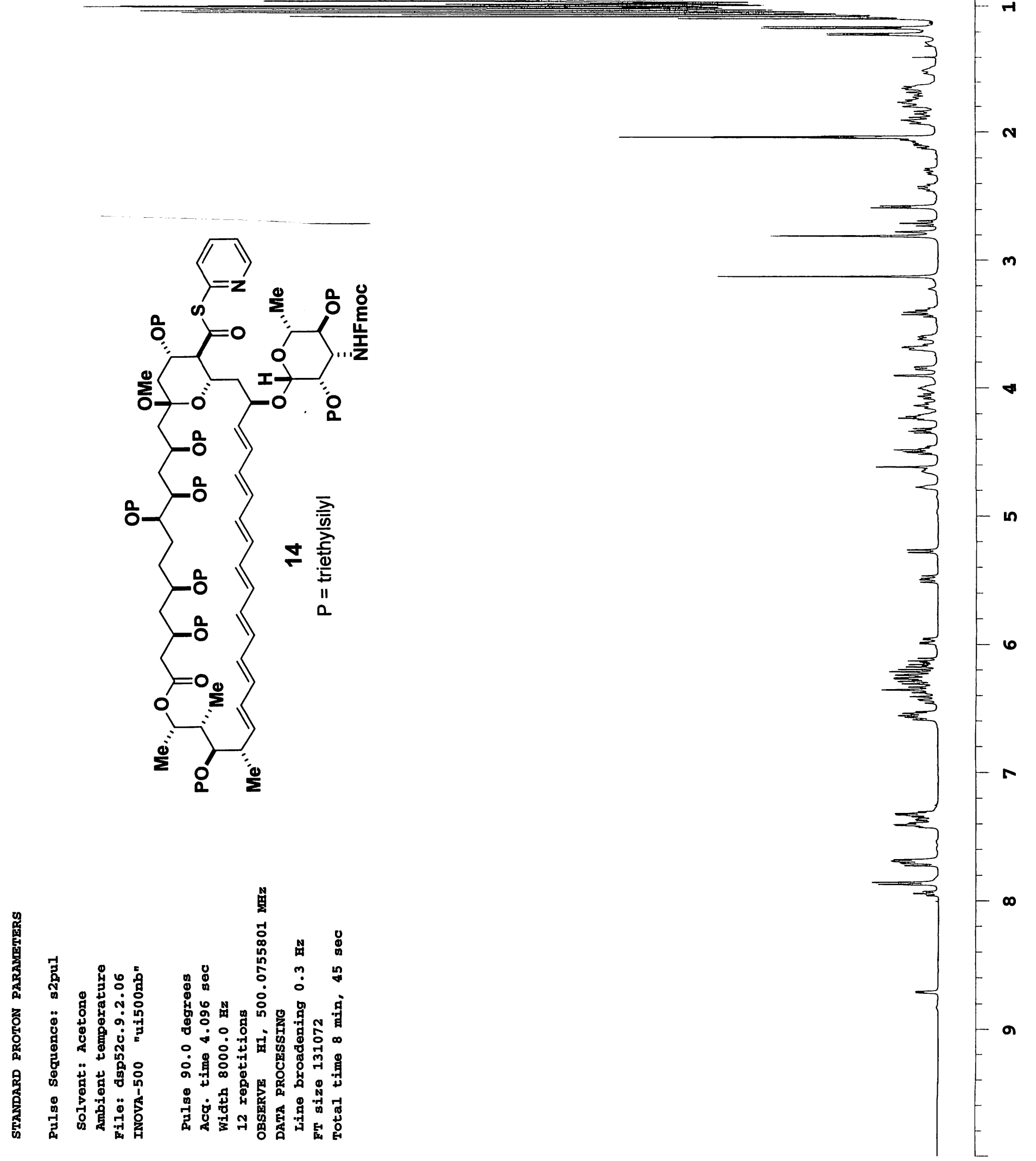

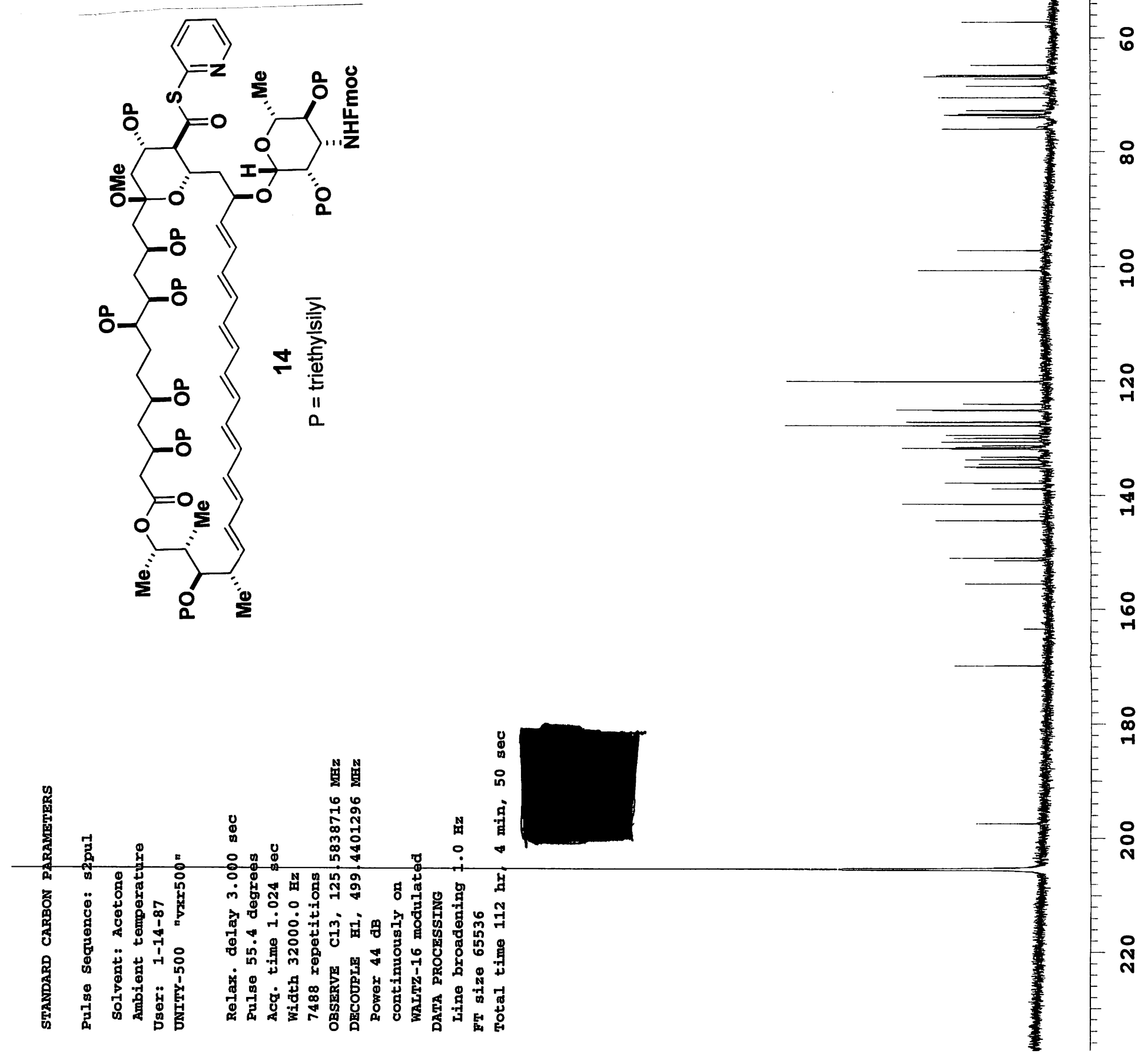

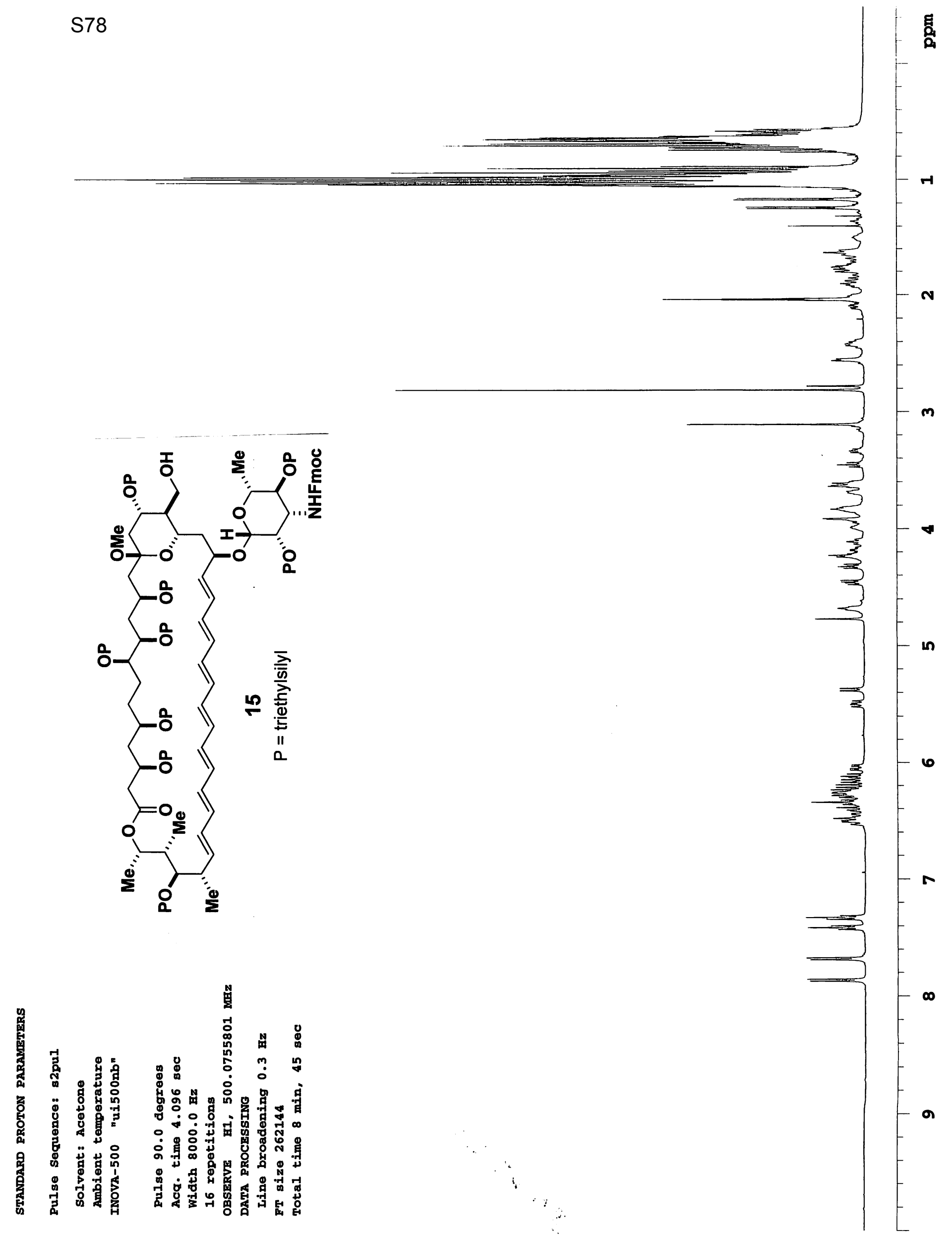

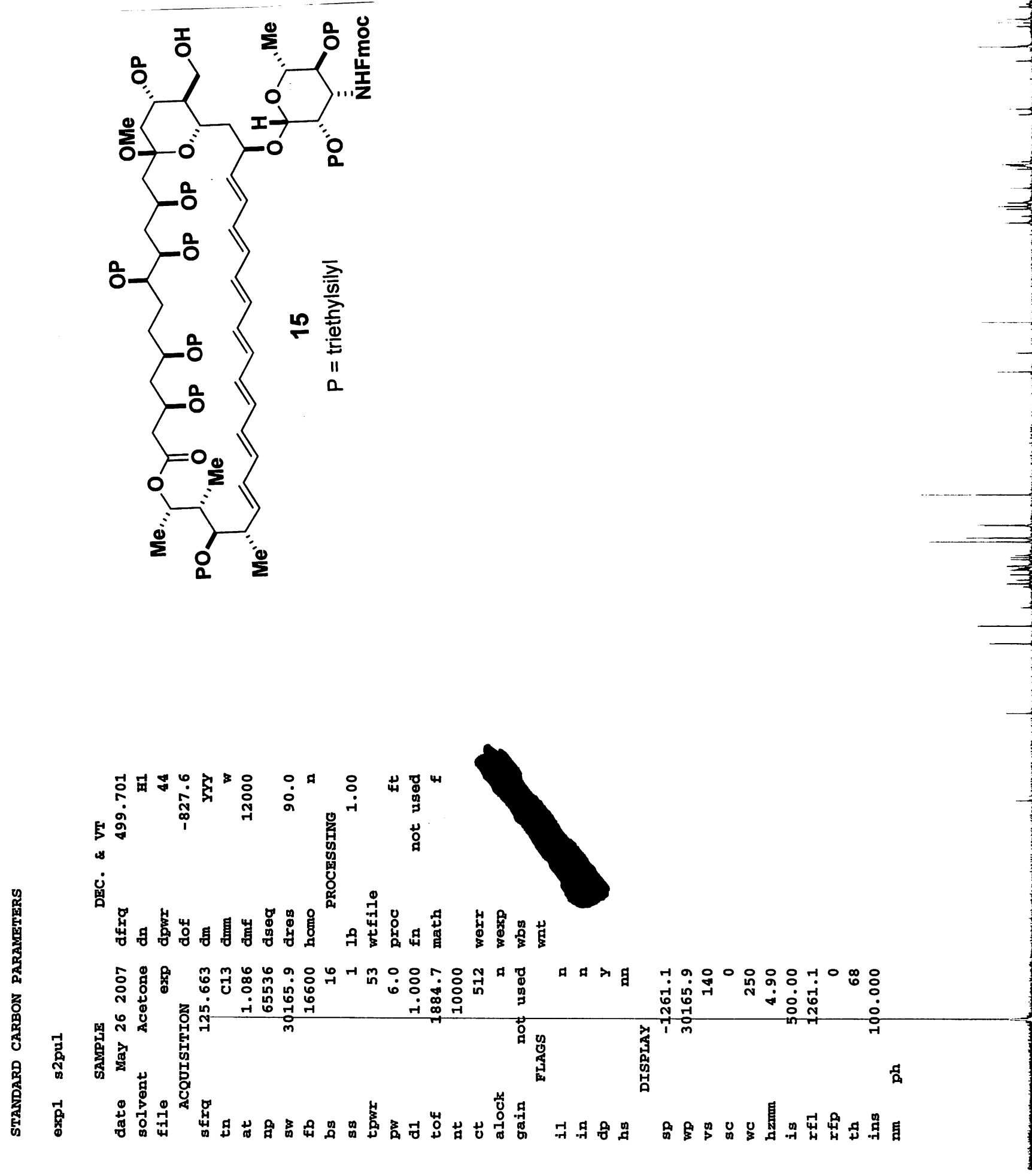

हี

오

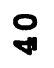

8

$\stackrel{\infty}{\infty}$

욱

옥

욤

0
6
-1

0
$\infty$
-1

옹

ํำ 

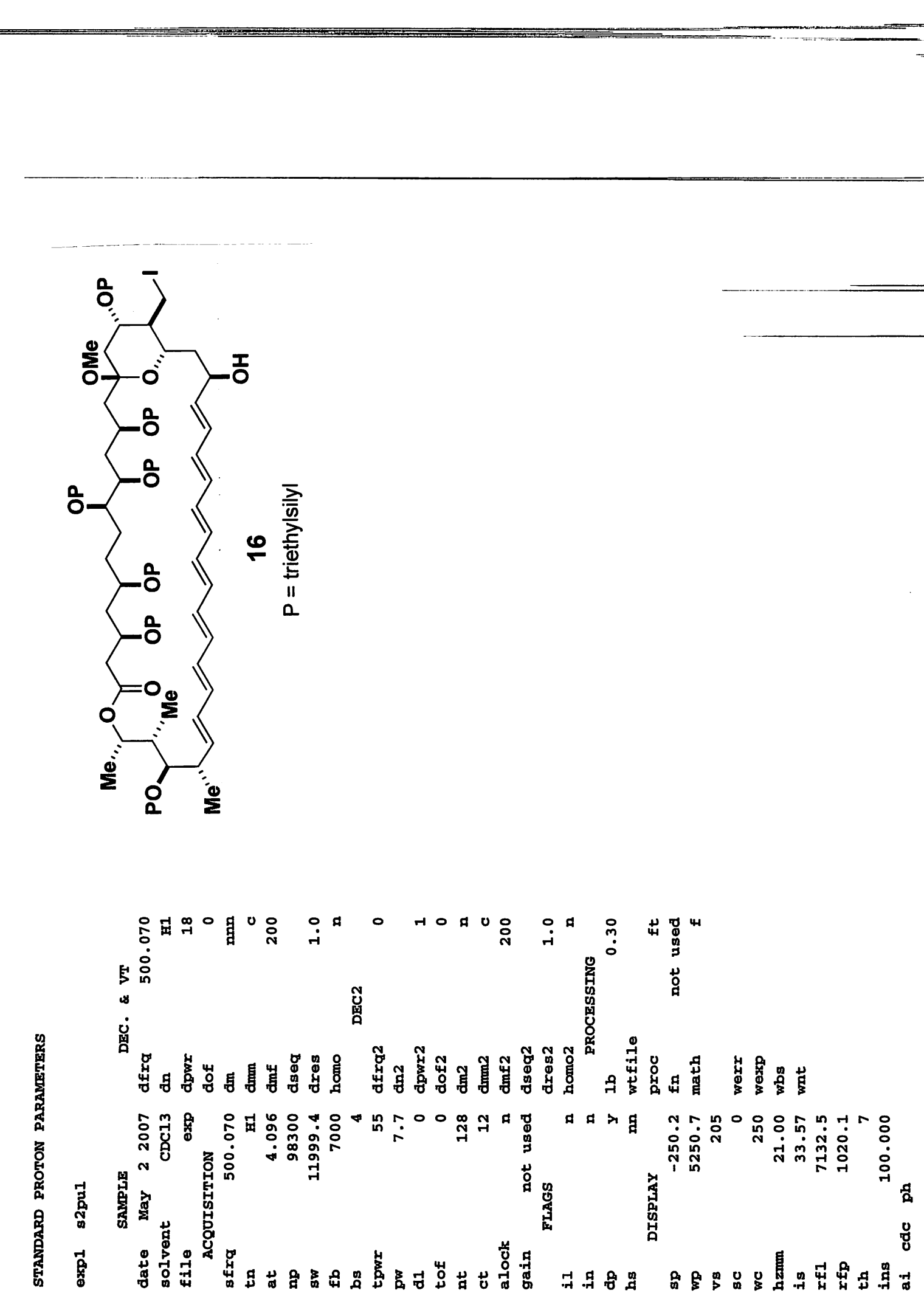


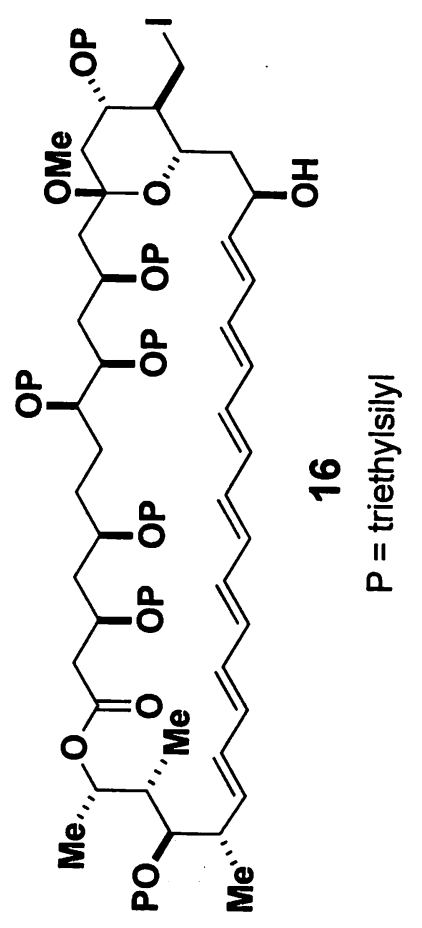

오

우

0

0
0
0
0
0
-0
-0
-0
-7

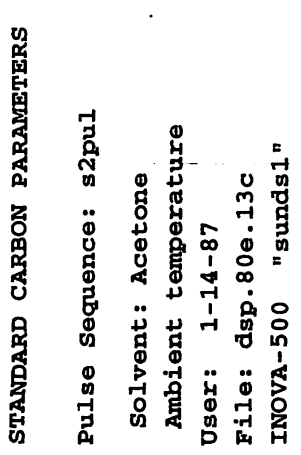

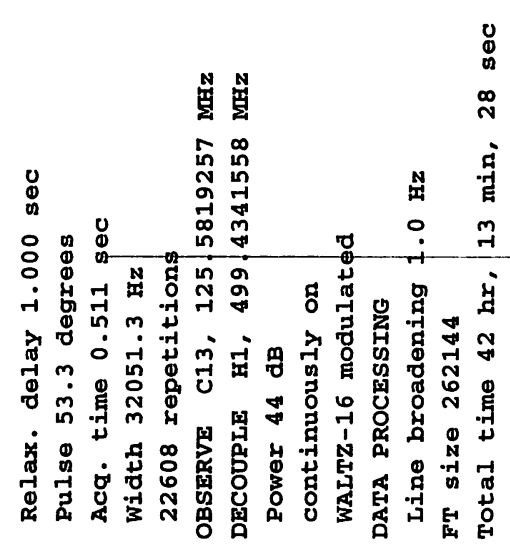

0
$\stackrel{\infty}{-1}$

옴

오 


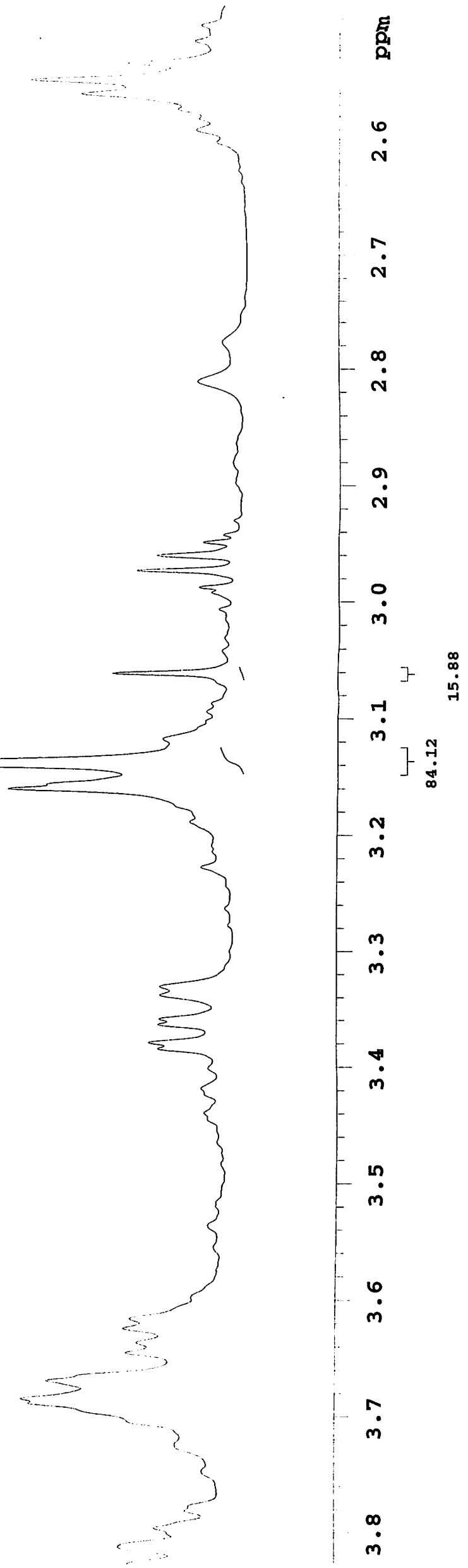




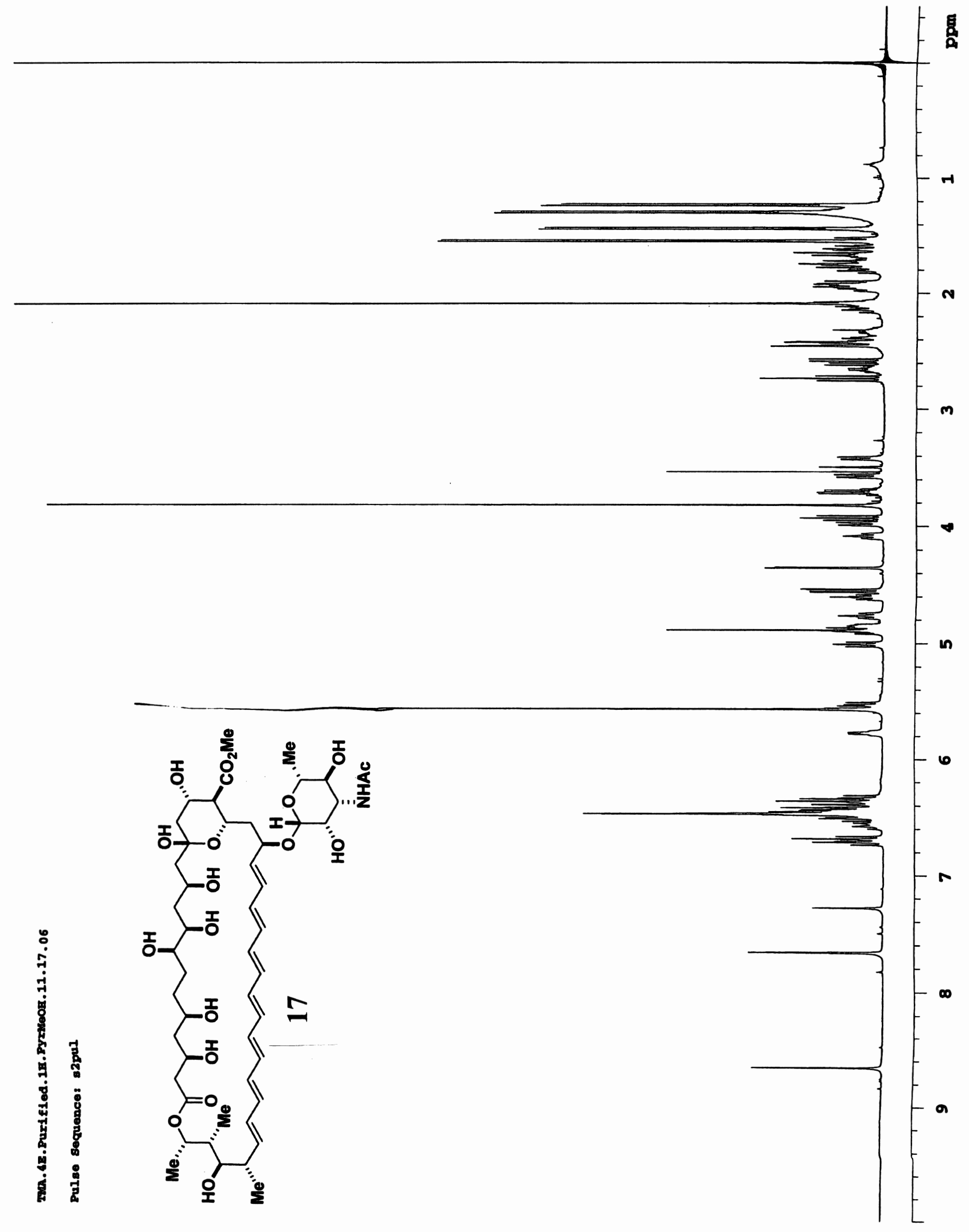



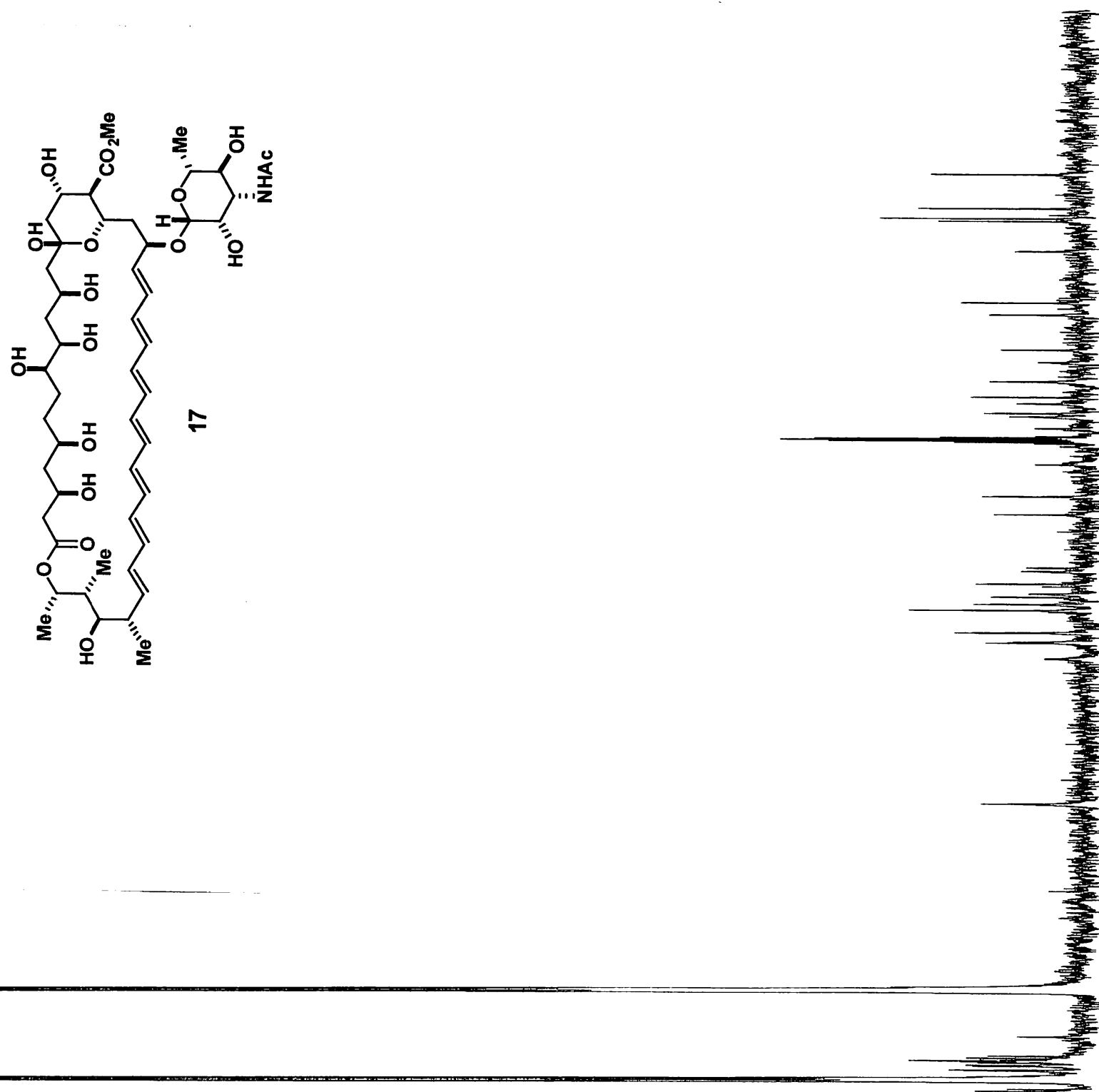

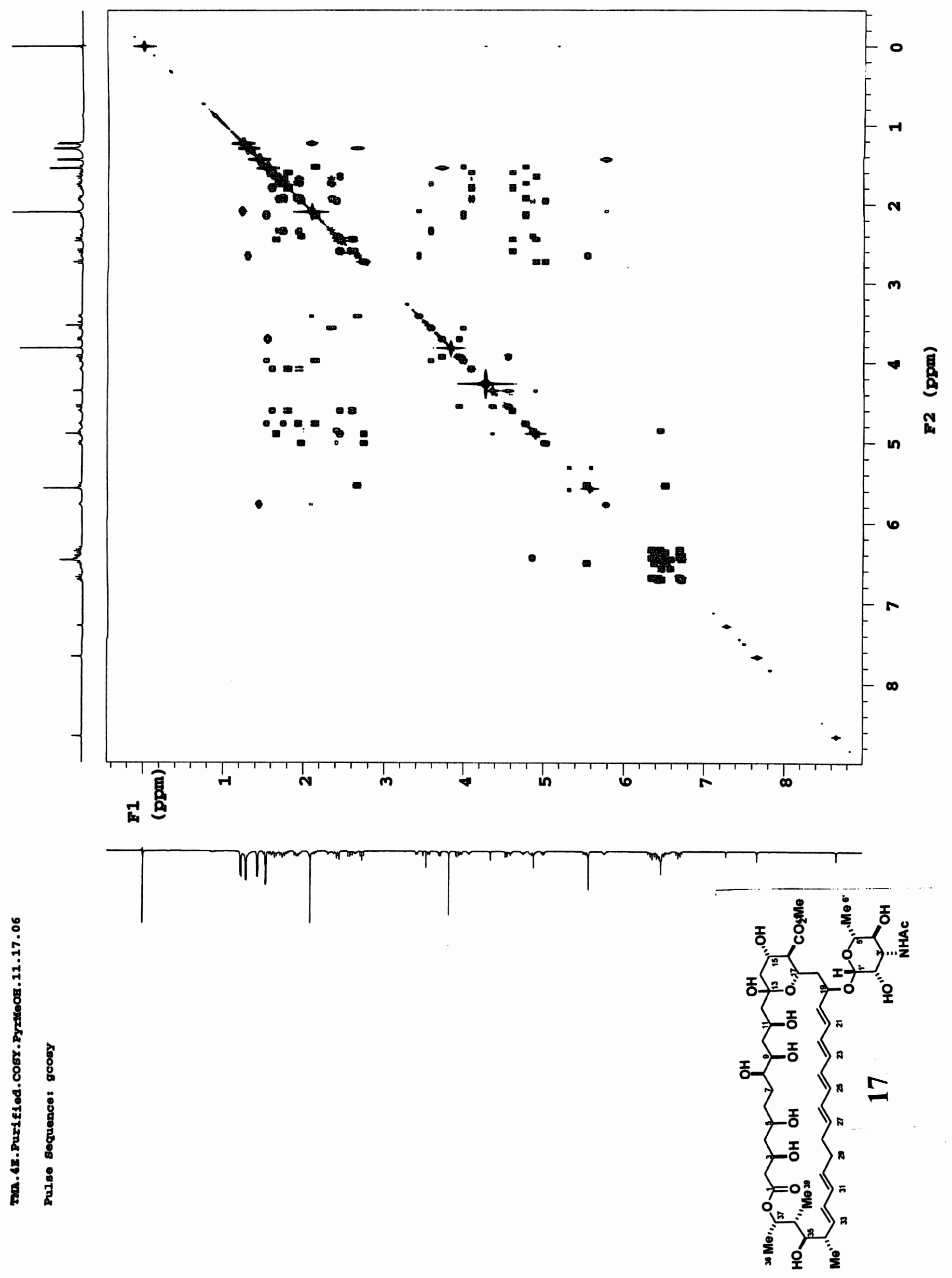

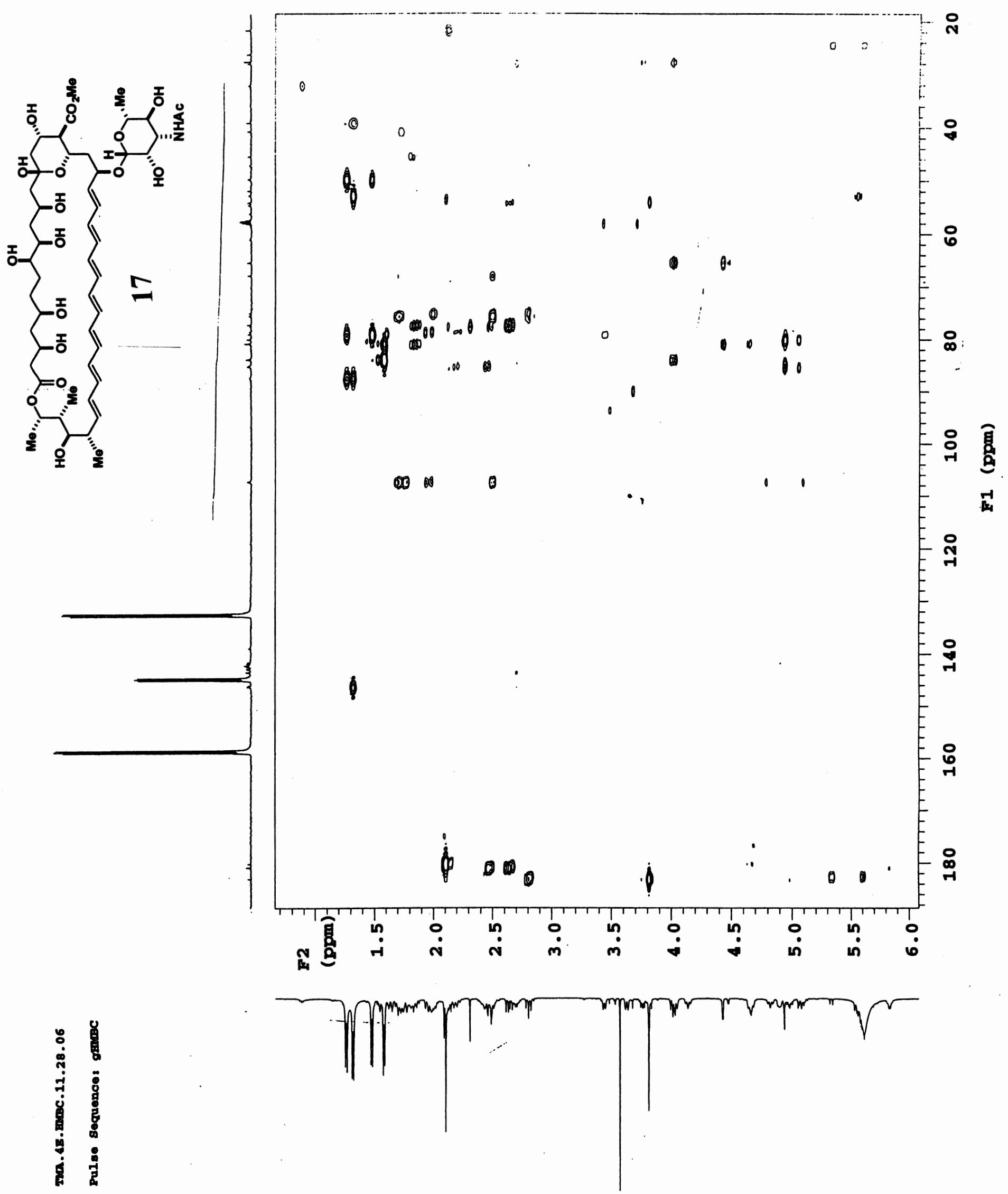
S87
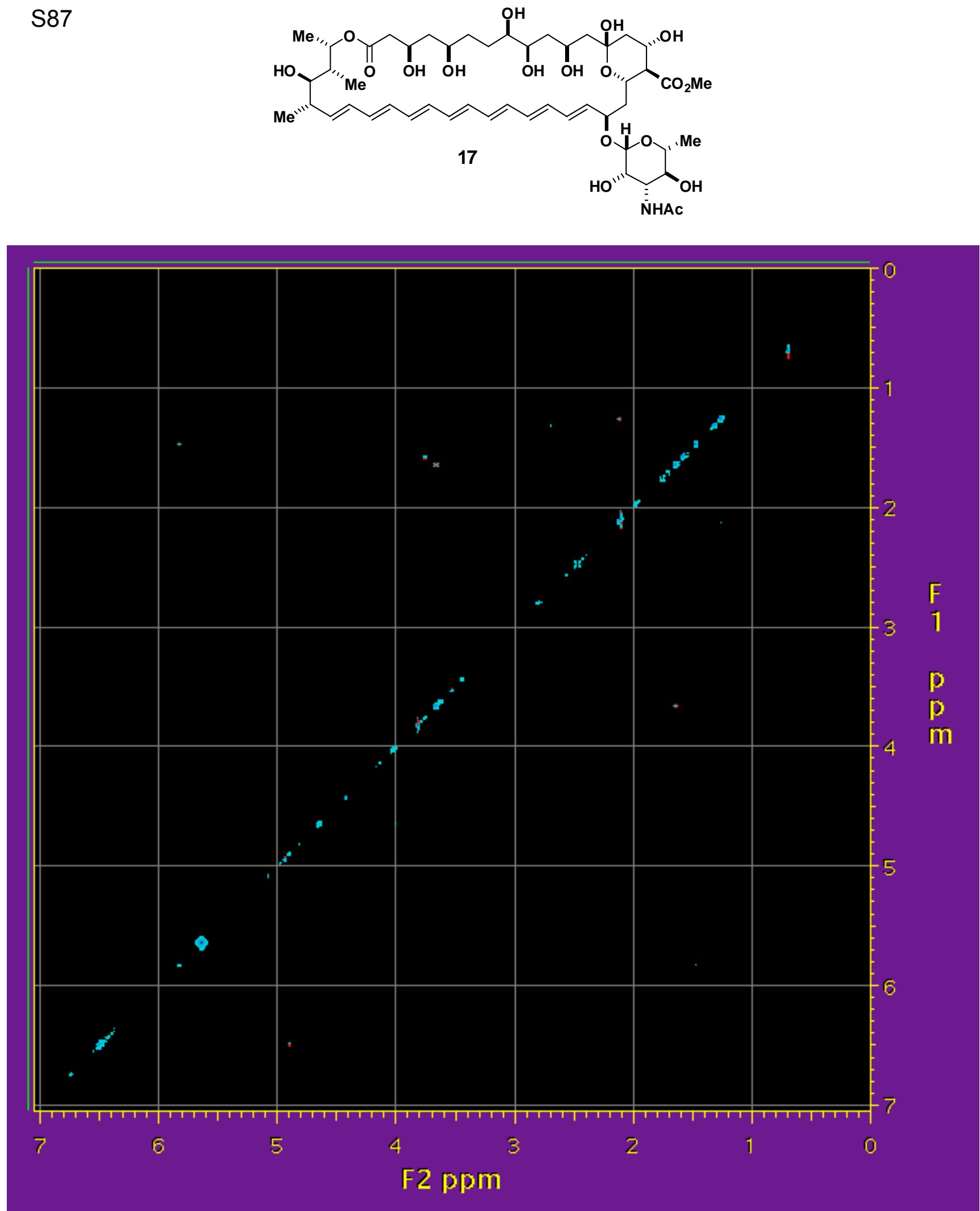

$500 \mathrm{MHz}$ diagonal COSYPS spectrum of 17 
S88
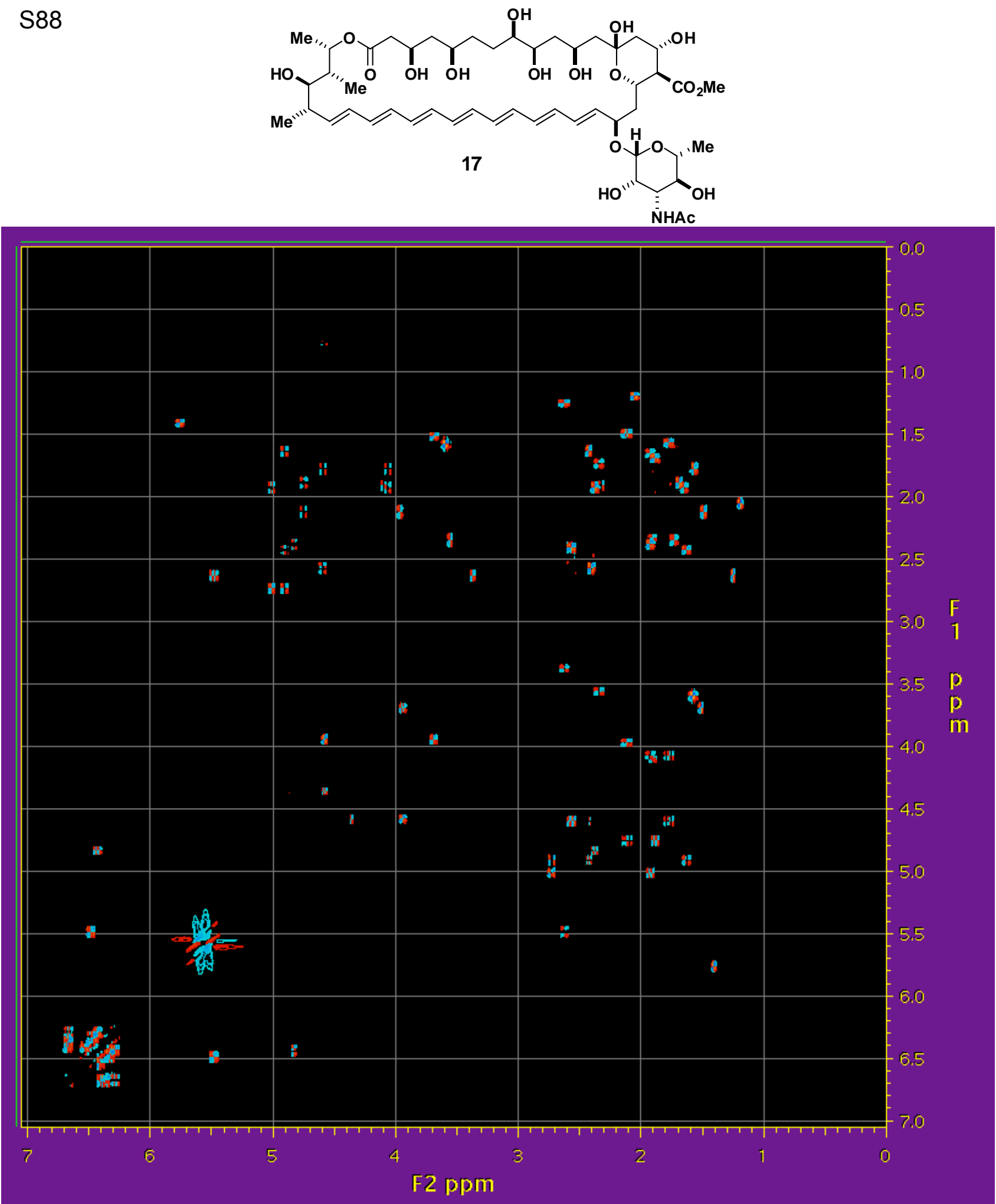

500 MHz diagonal-suppressed COSYPS spectrum of 17 
S89
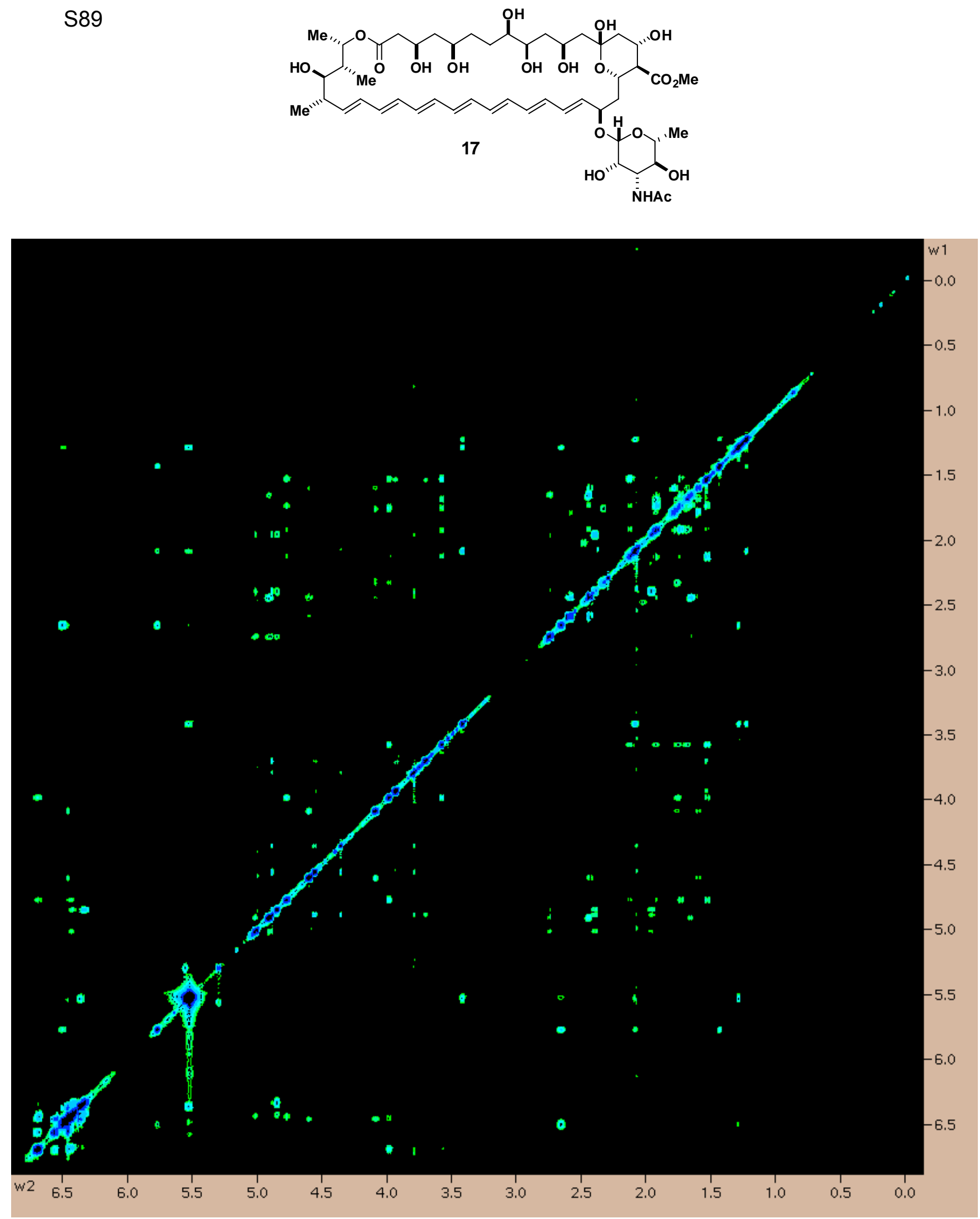

$600 \mathrm{MHz}$ NOESY spectrum of 17 

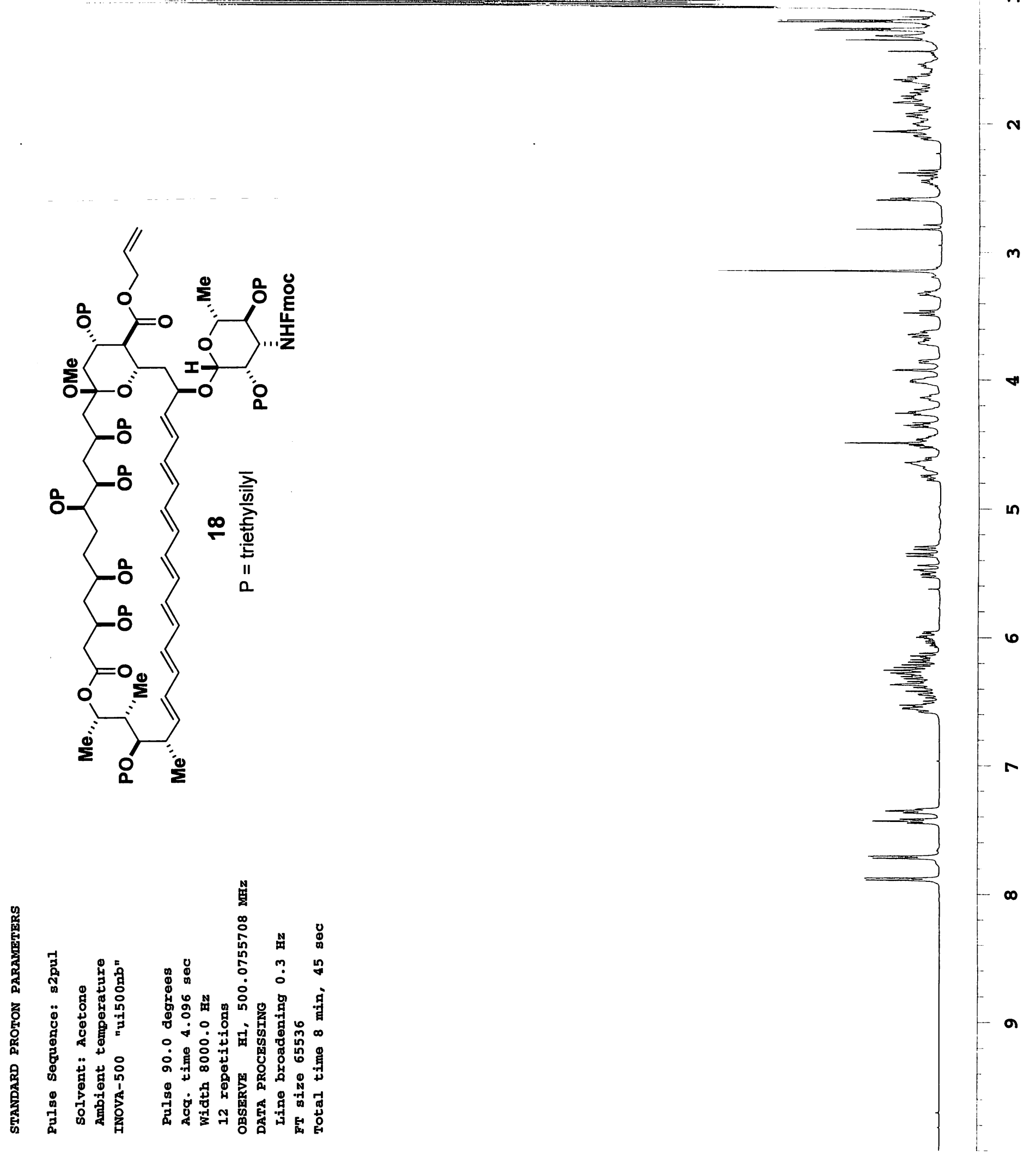


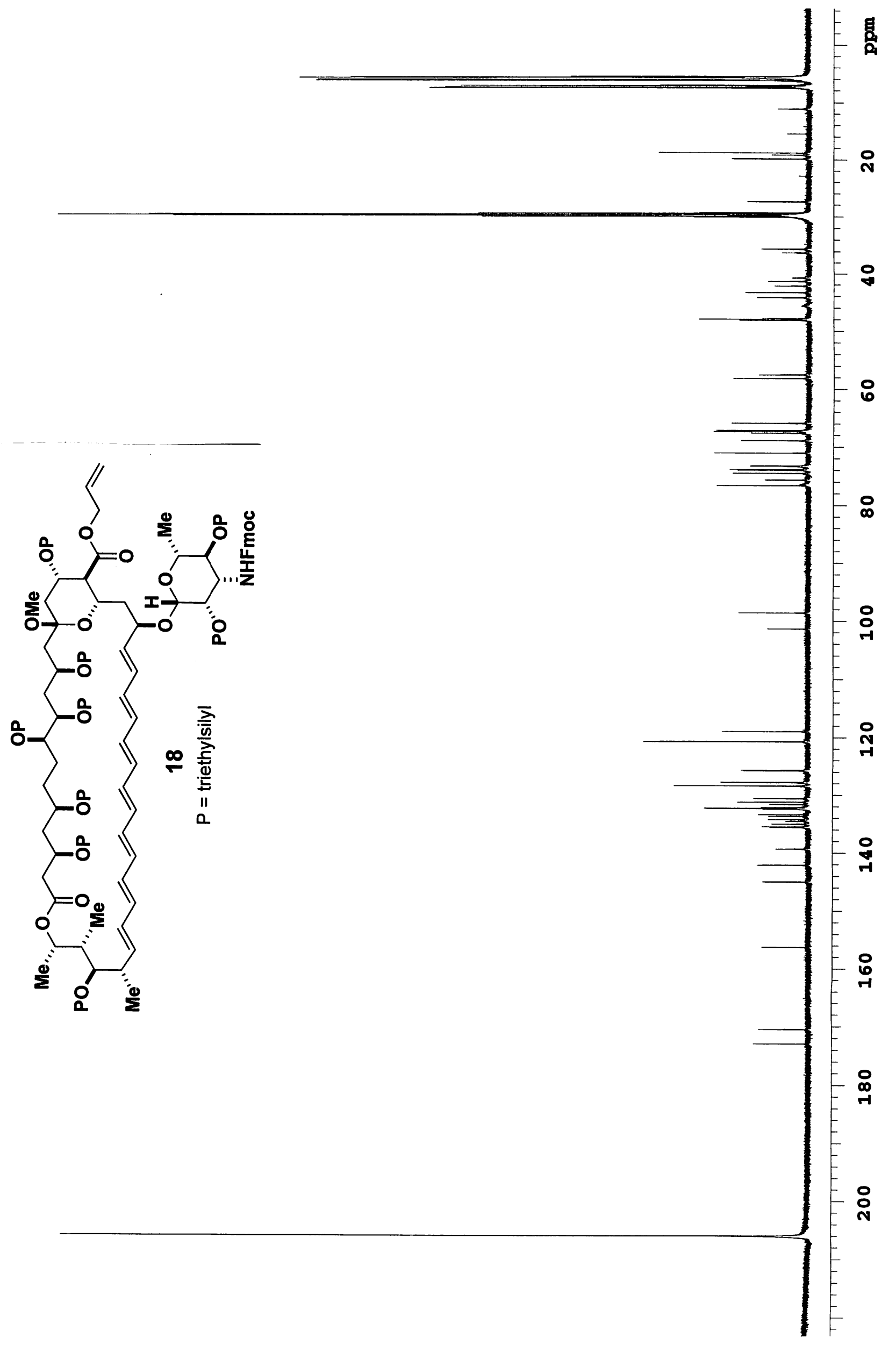

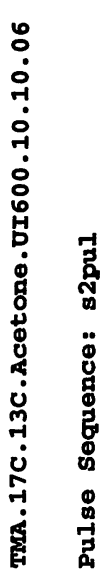



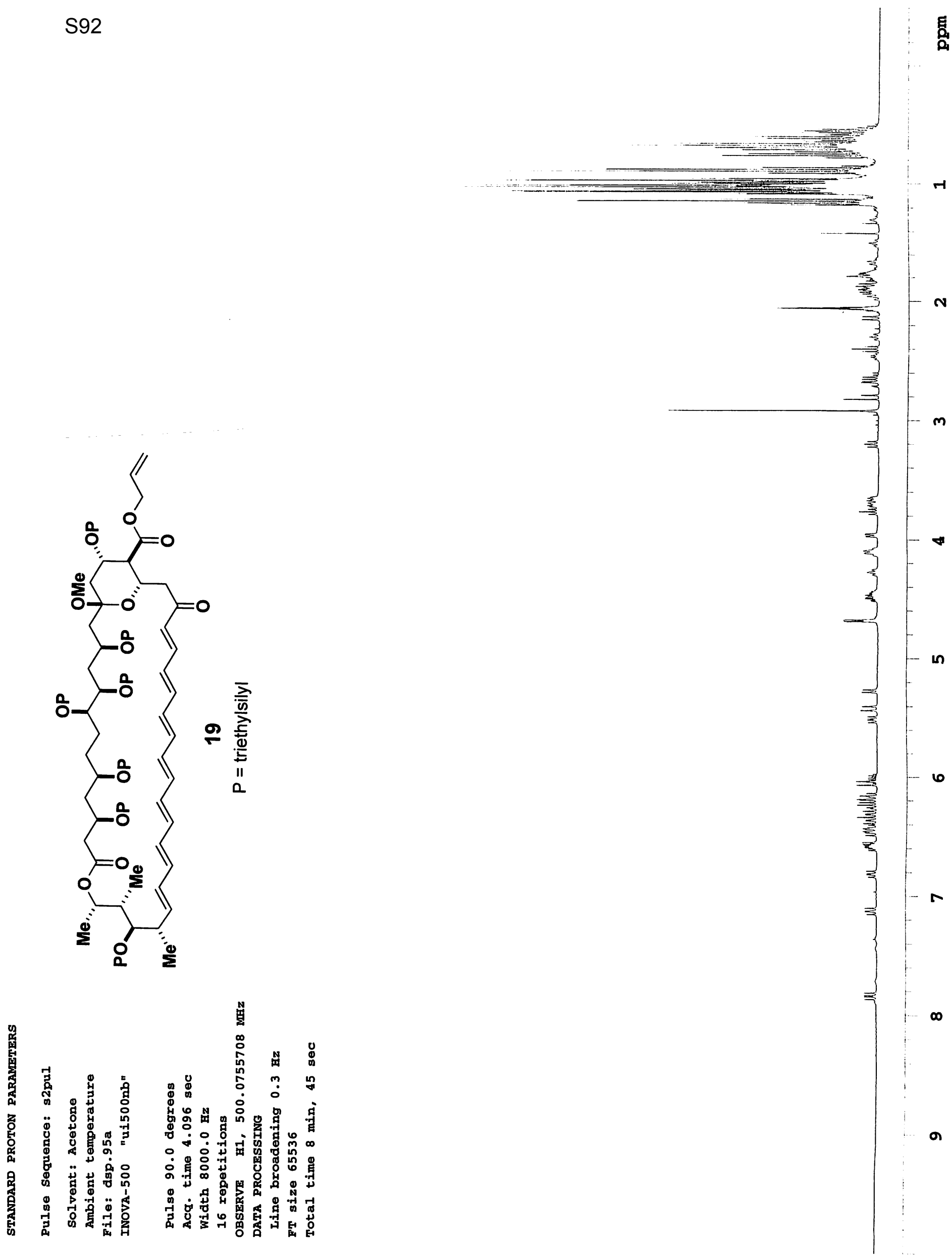
S93
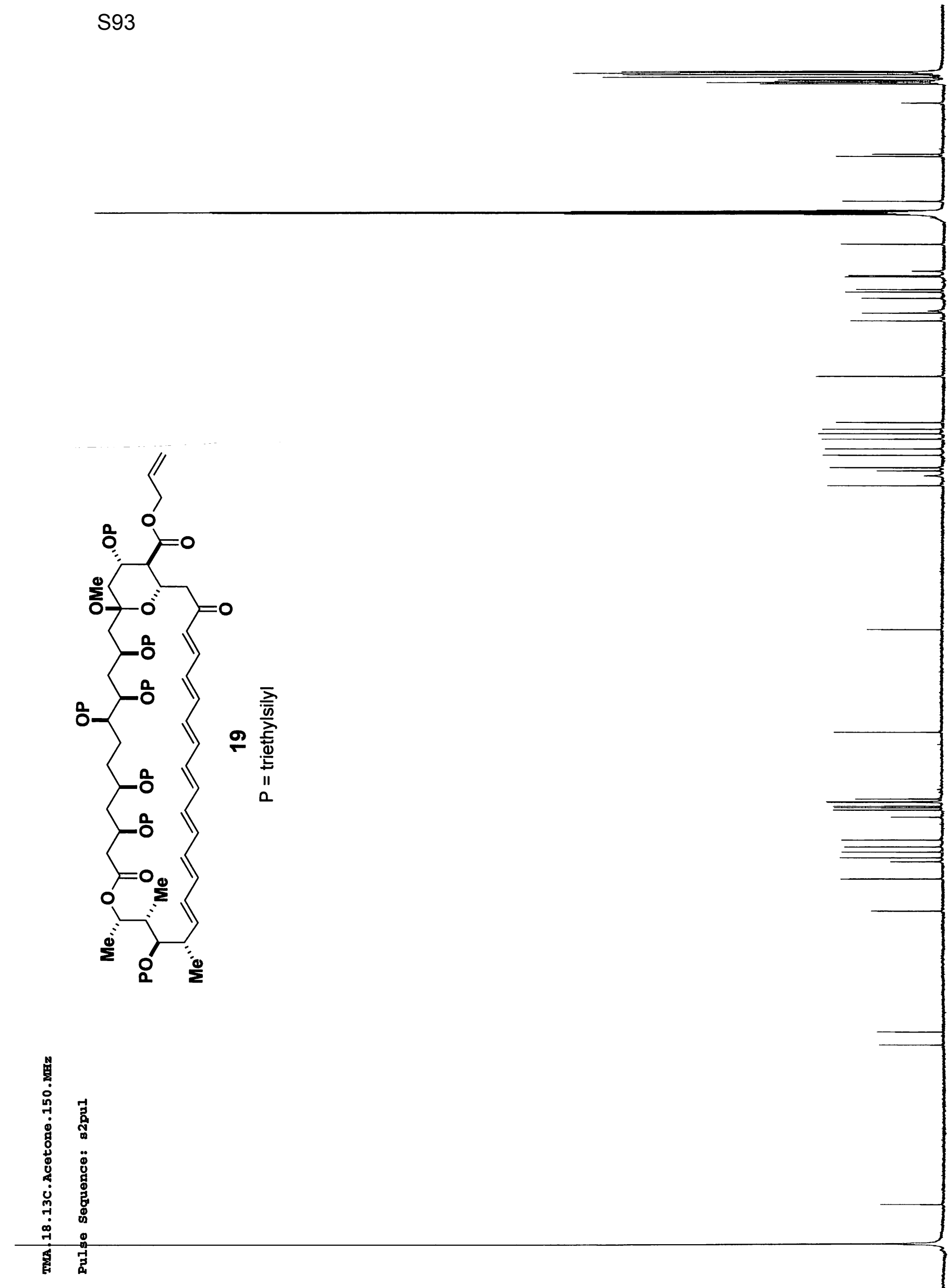

0

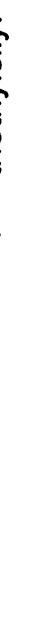




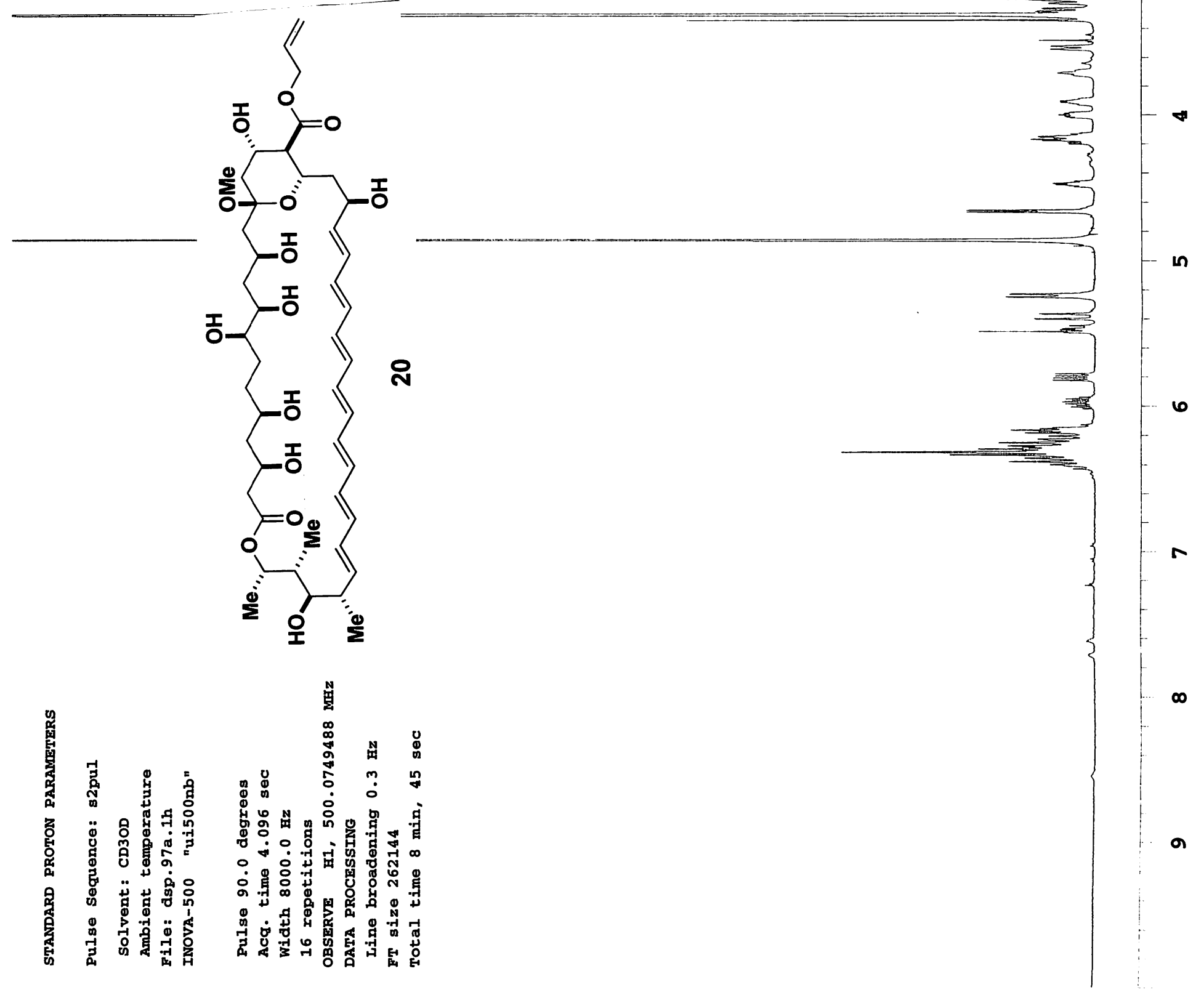




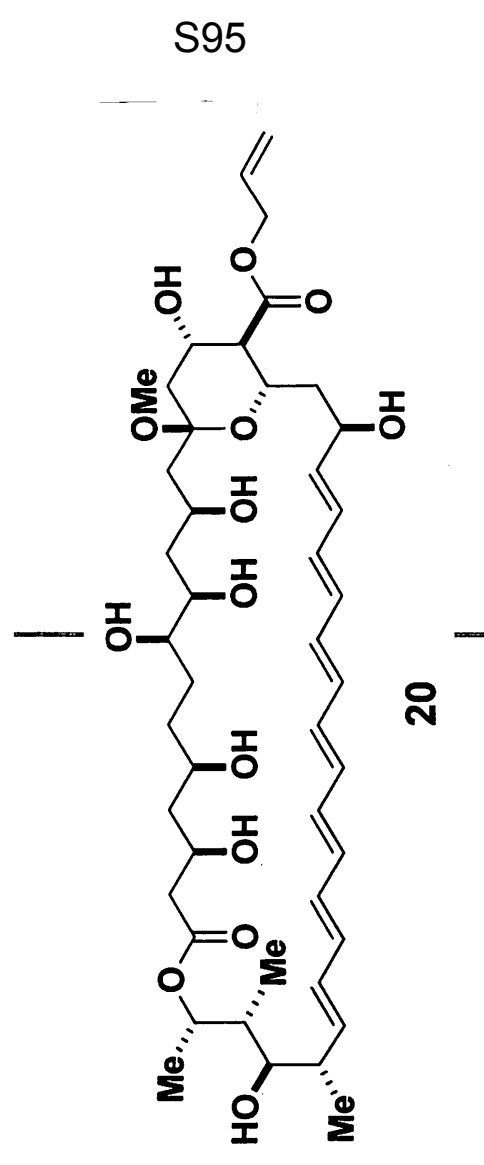

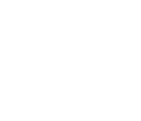




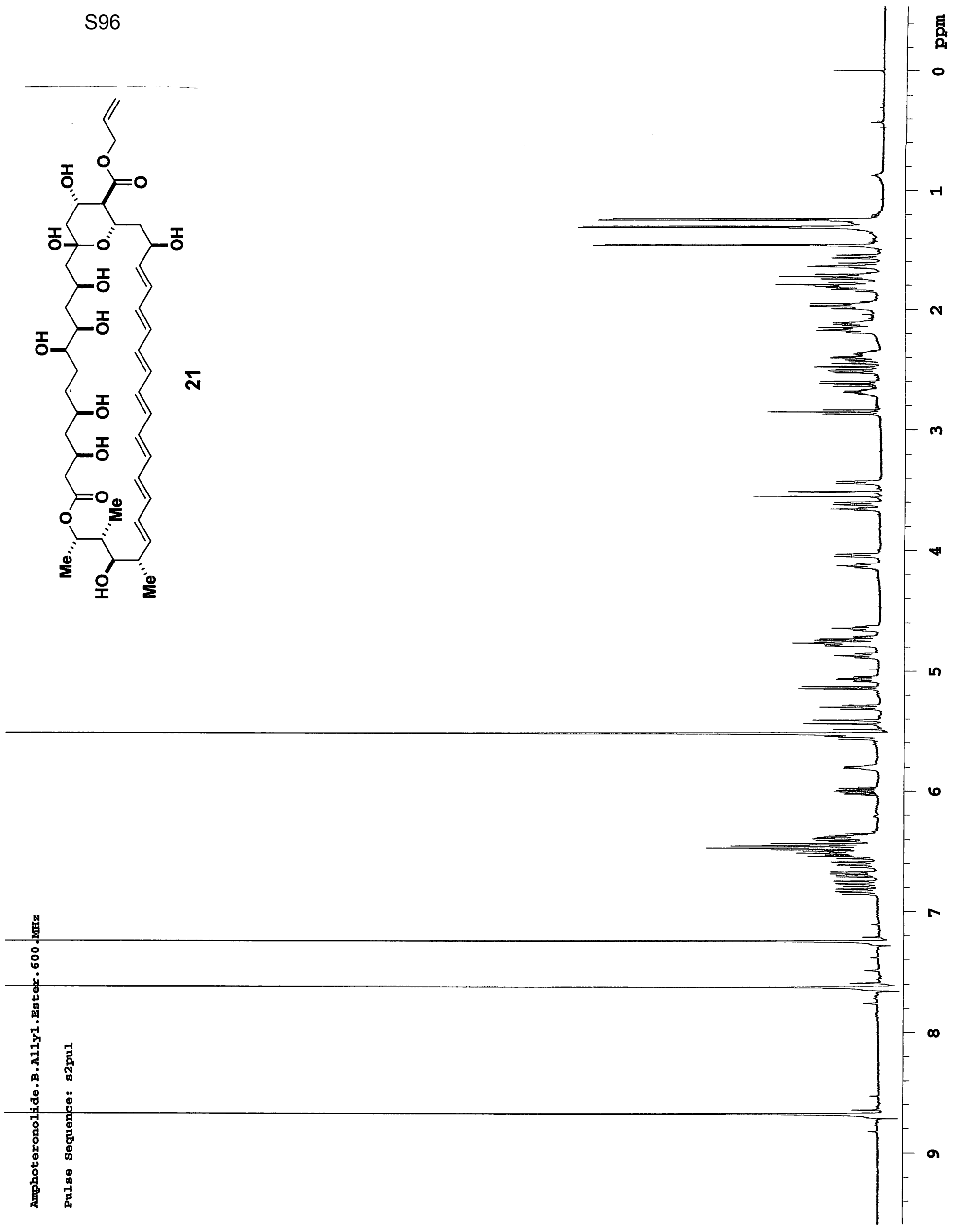




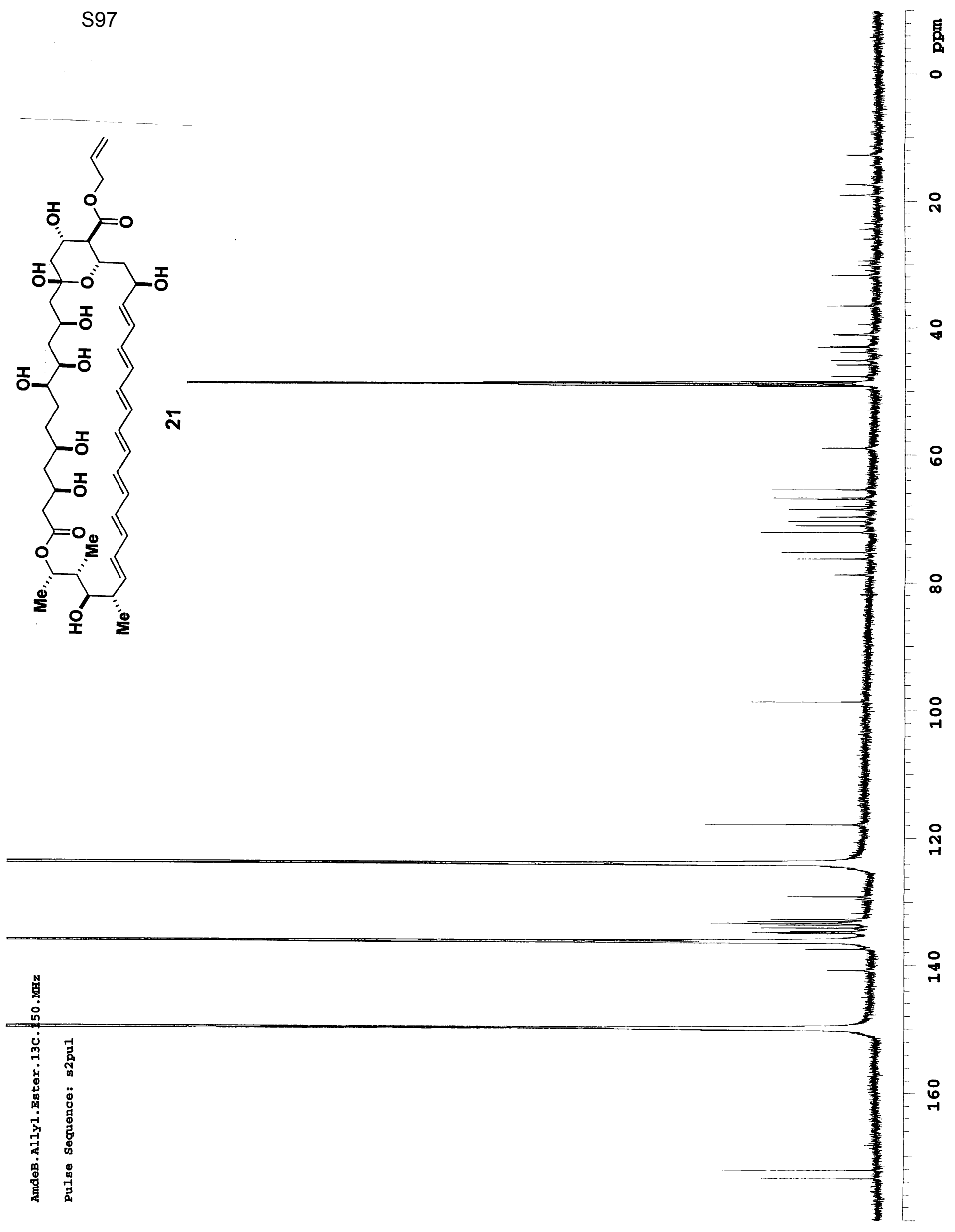




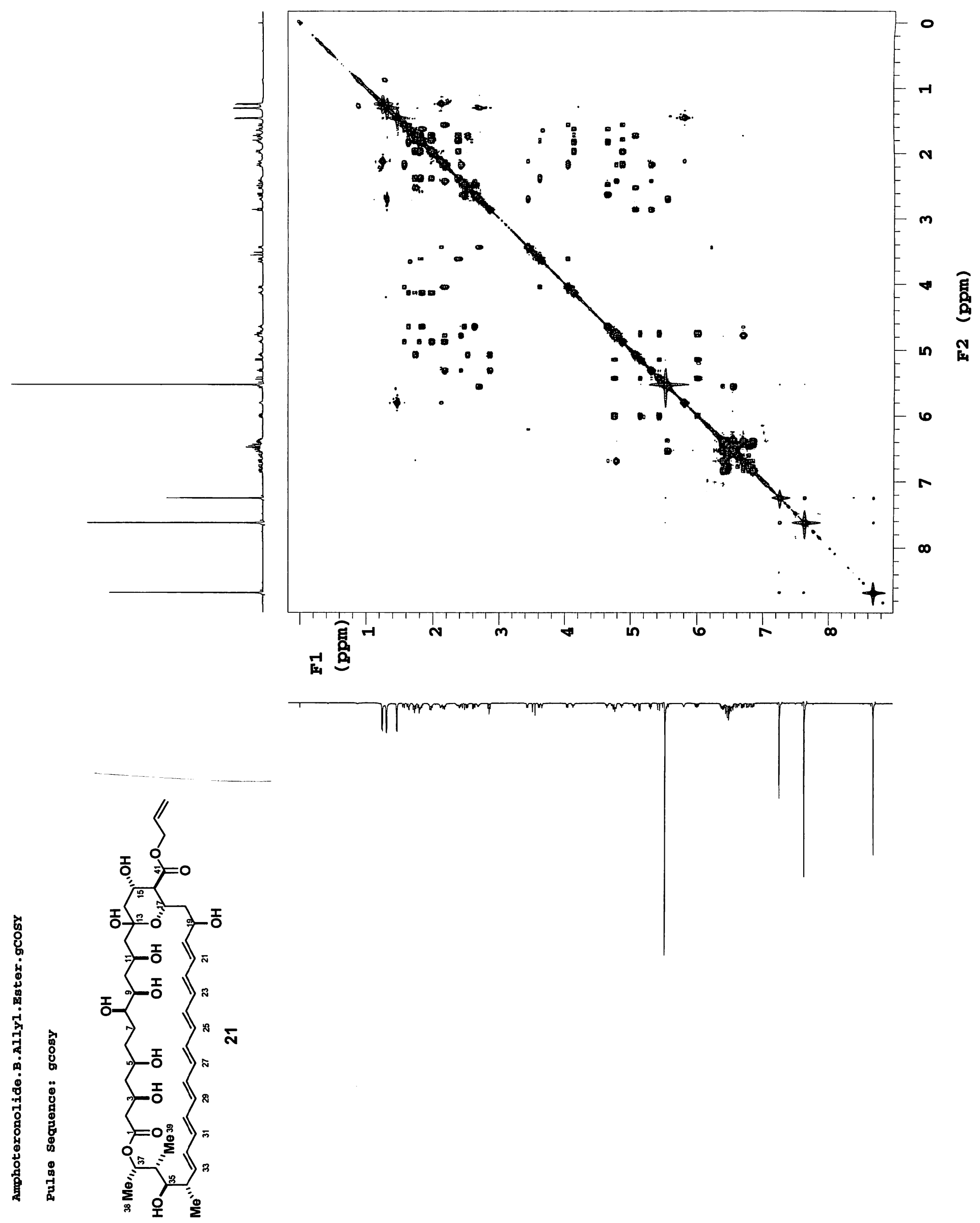


S99
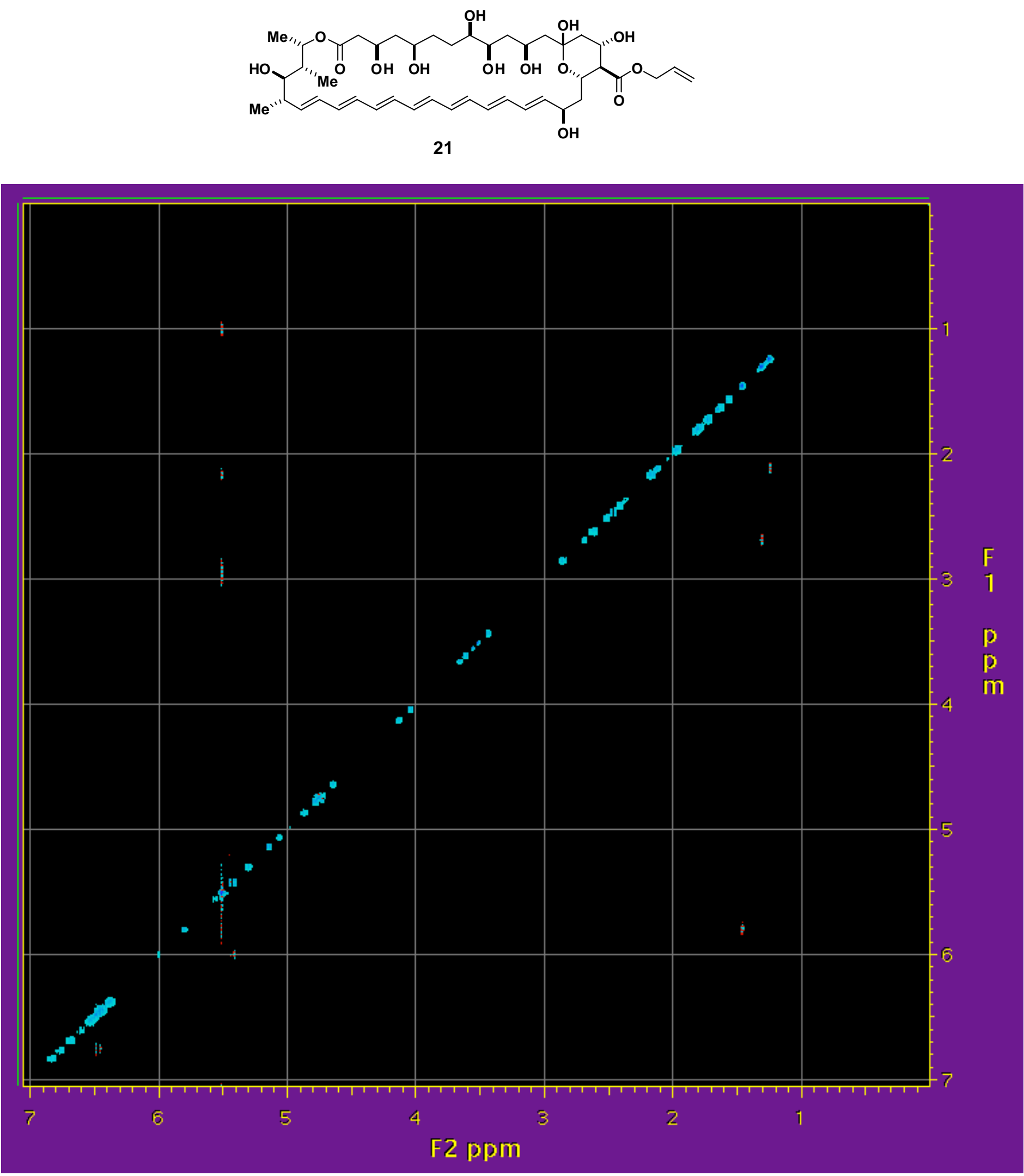

$600 \mathrm{MHz}$ diagonal COSYPS spectrum of 21 
S100
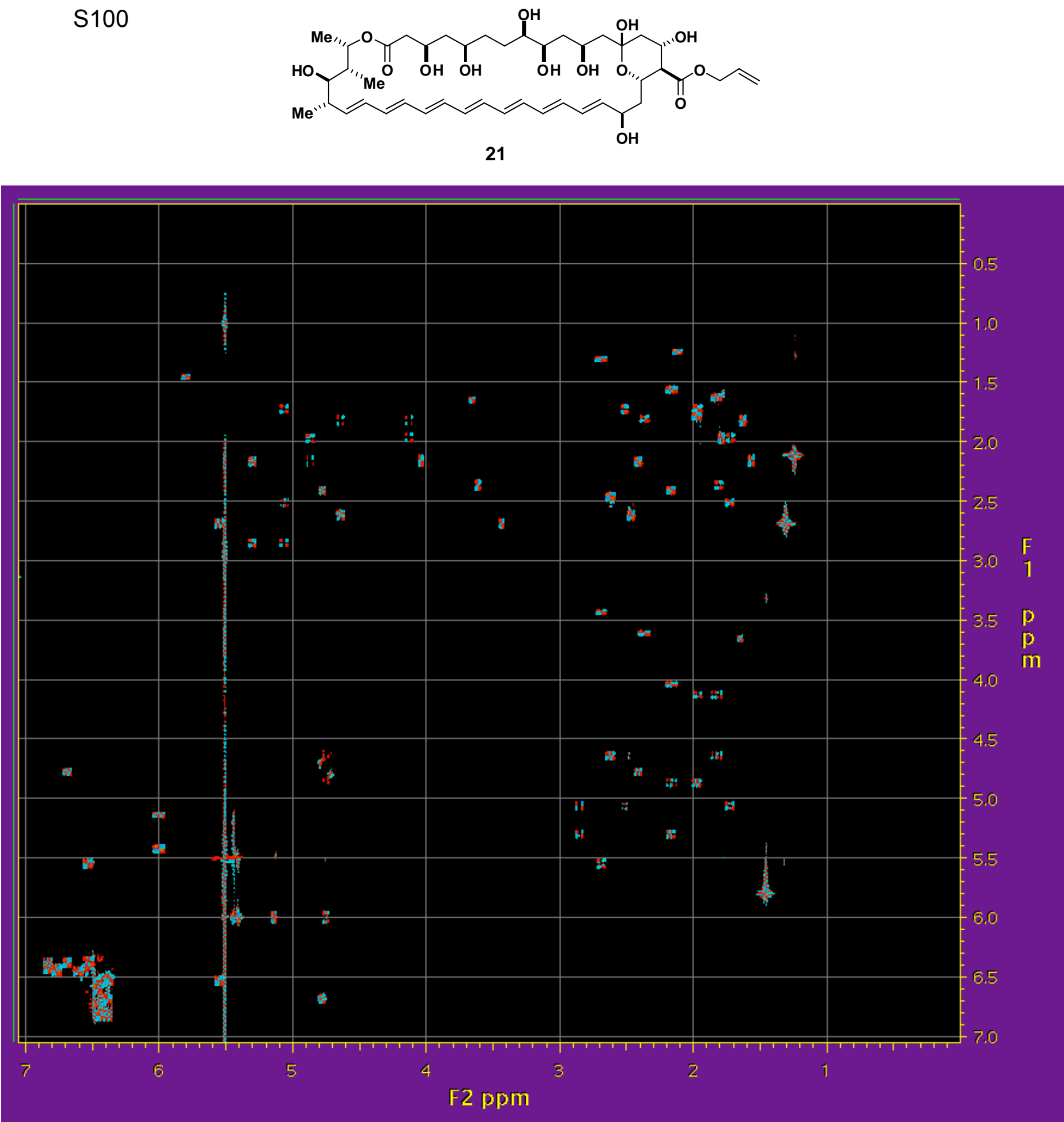

$600 \mathrm{MHz}$ diagonal-suppressed COSYPS spectrum of 21 
S101
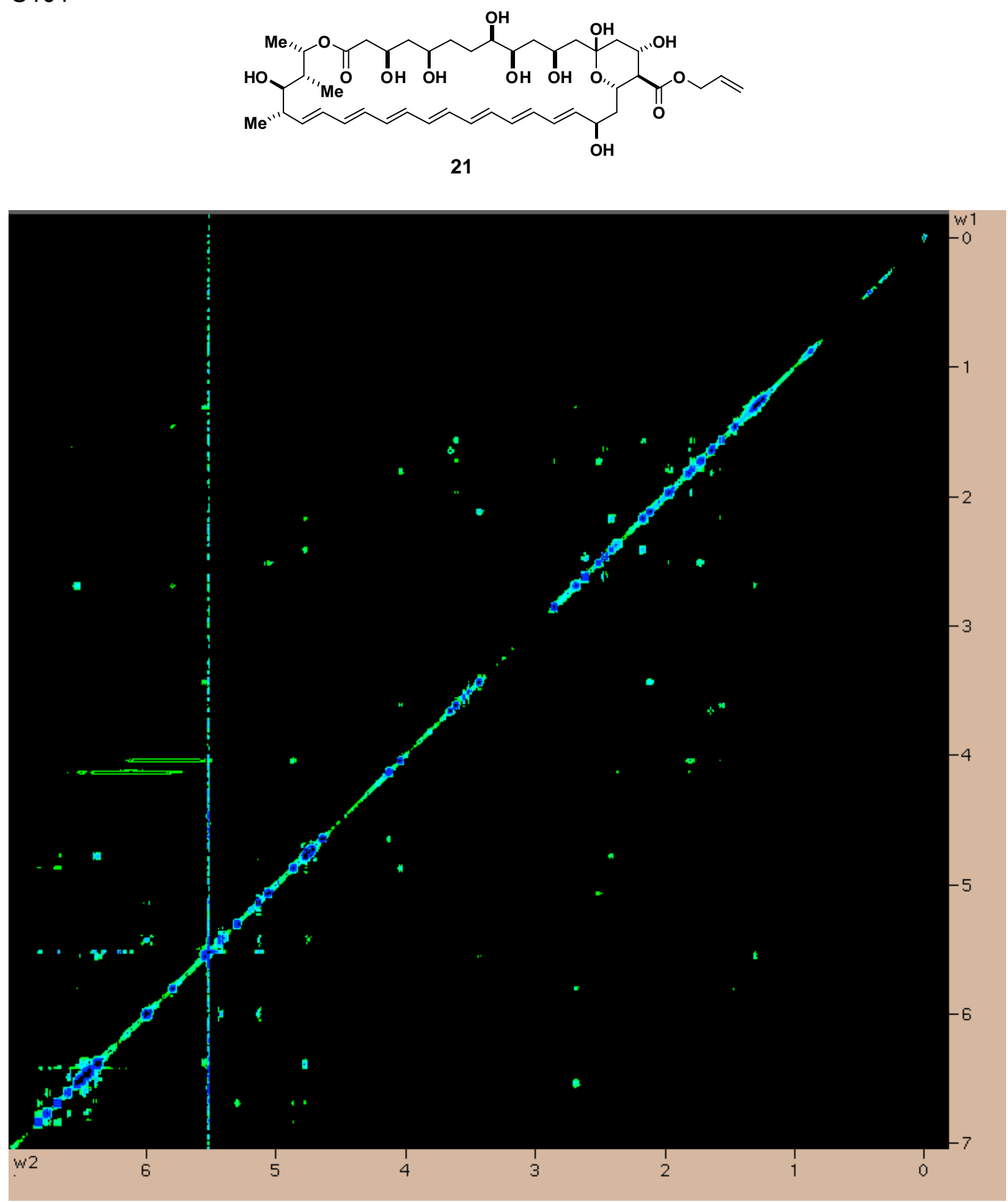

$600 \mathrm{MHz}$ NOESY Spectrum of 21 

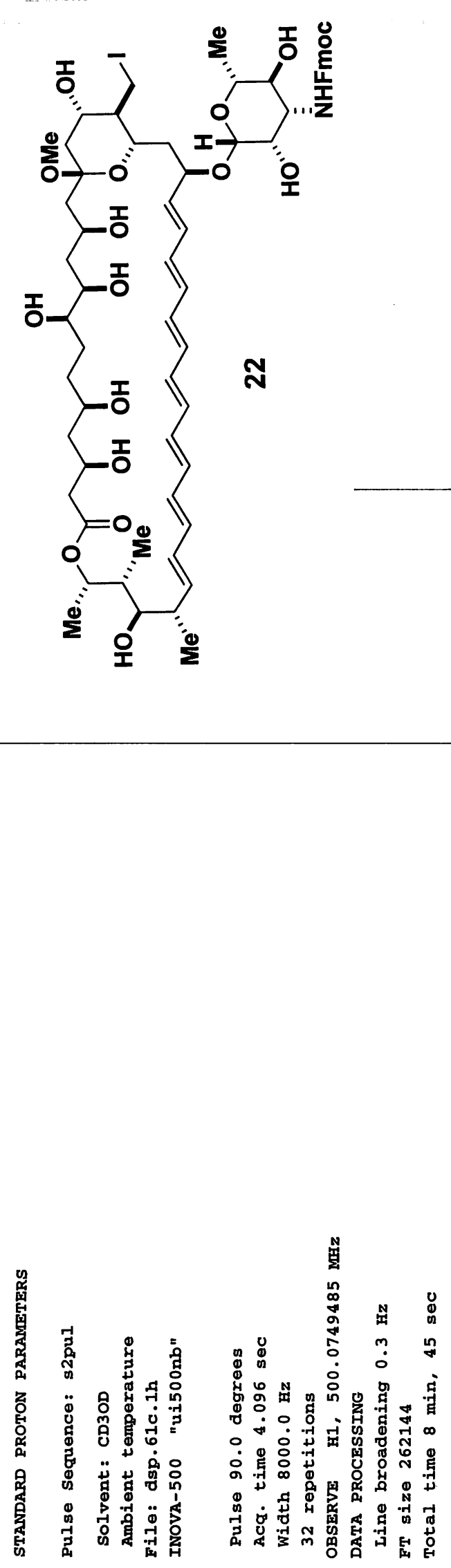

$\infty$

$a$ 

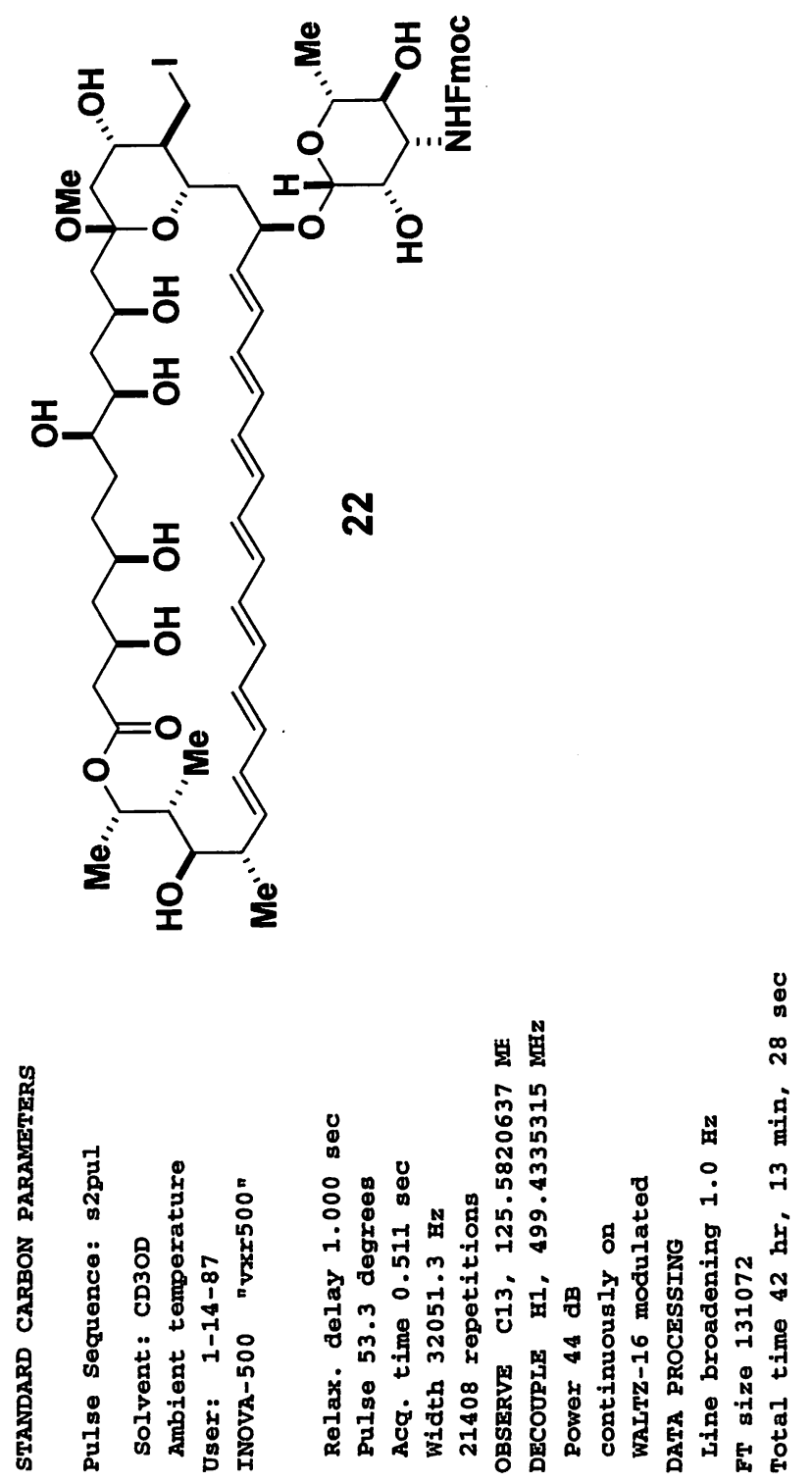

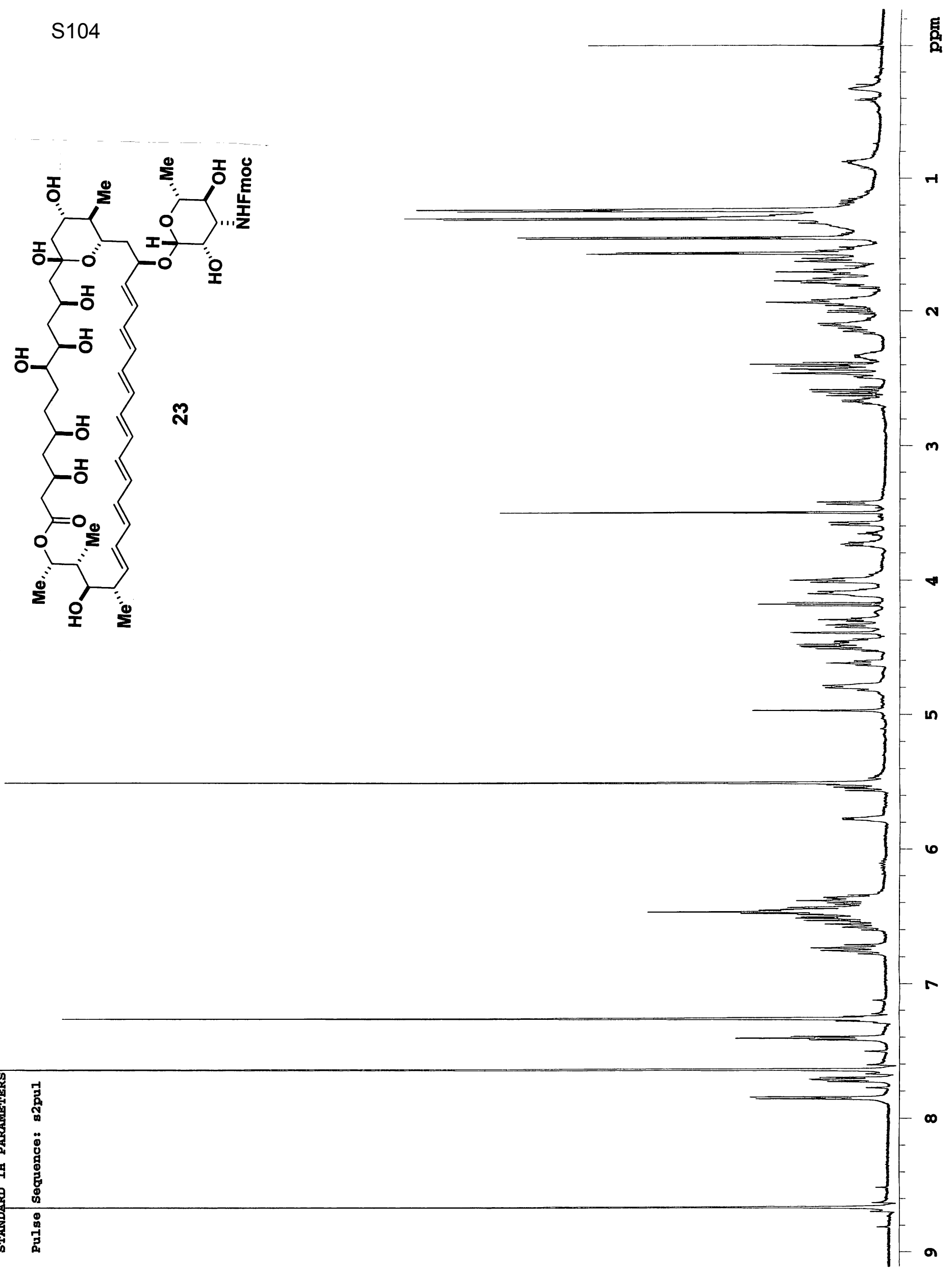


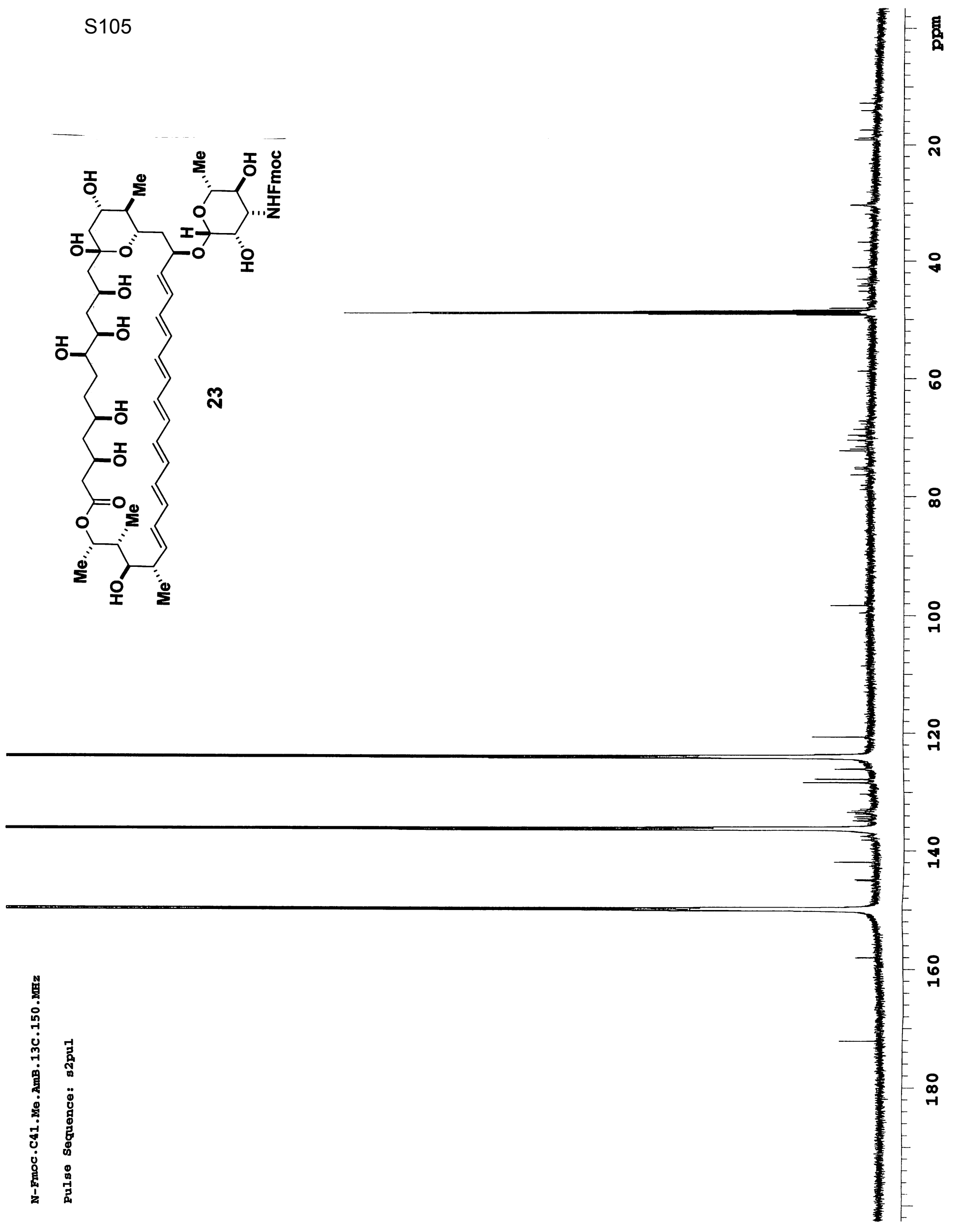




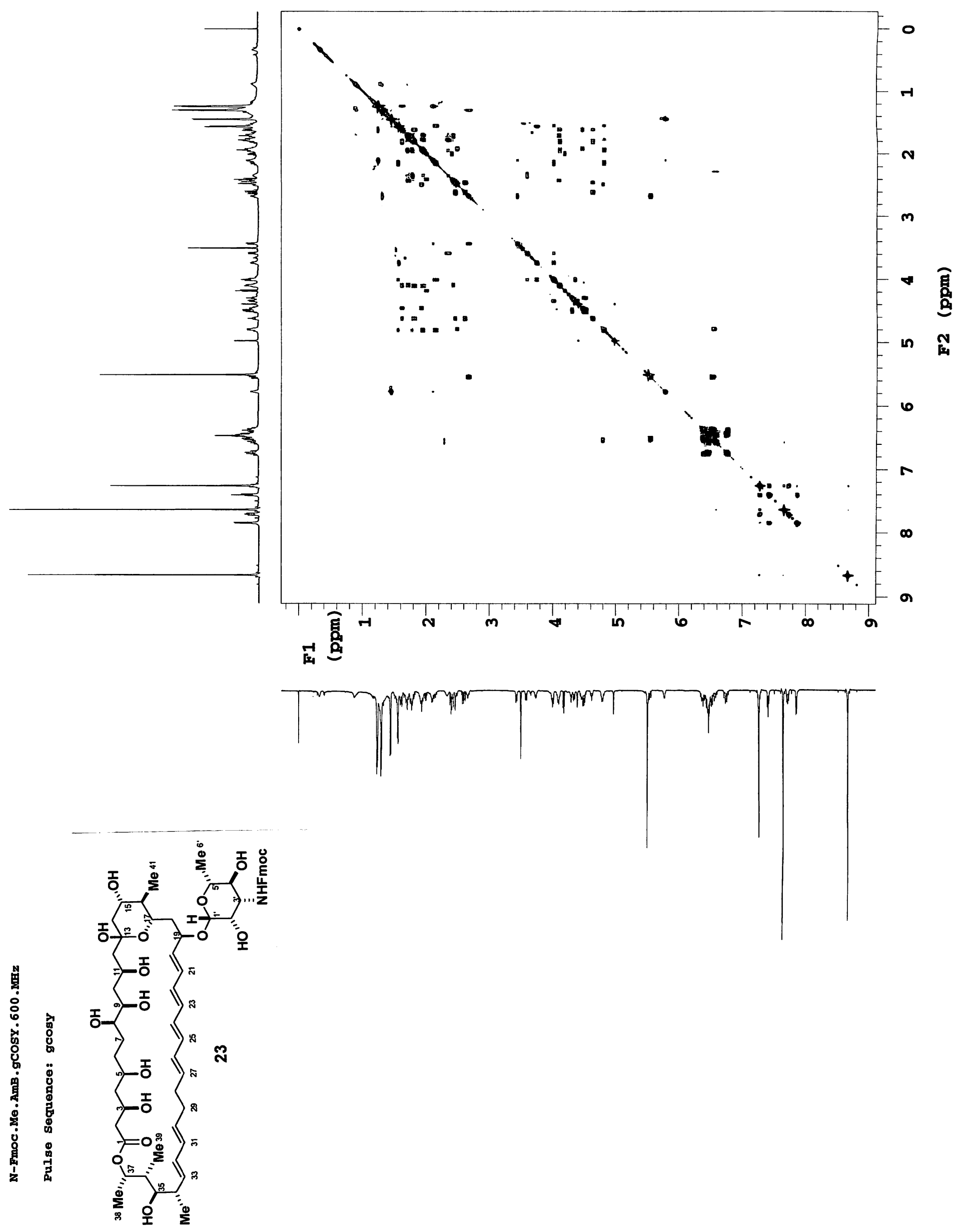


S107
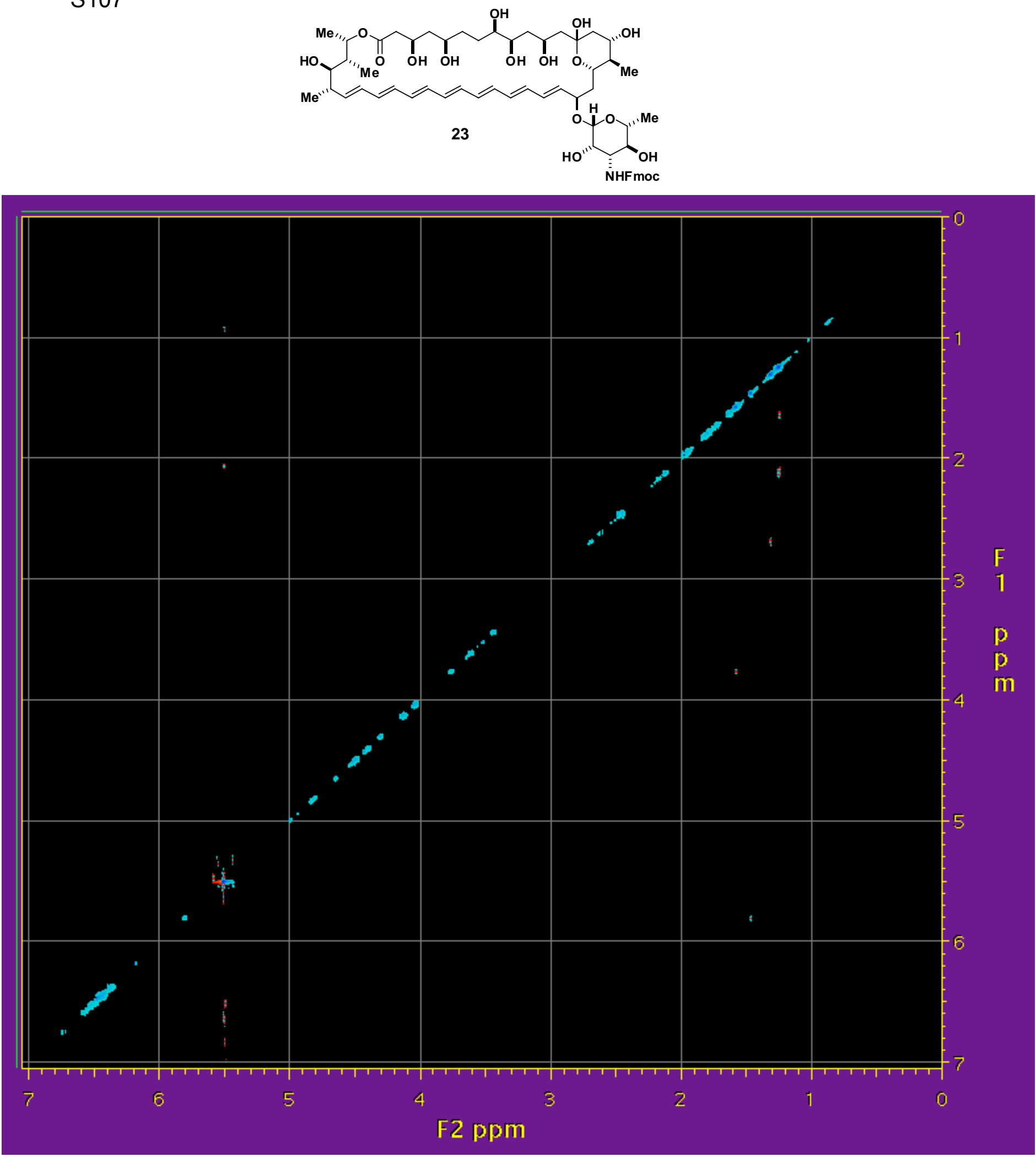

$500 \mathrm{MHz}$ diagonal COSYPS spectrum of 23 
S108
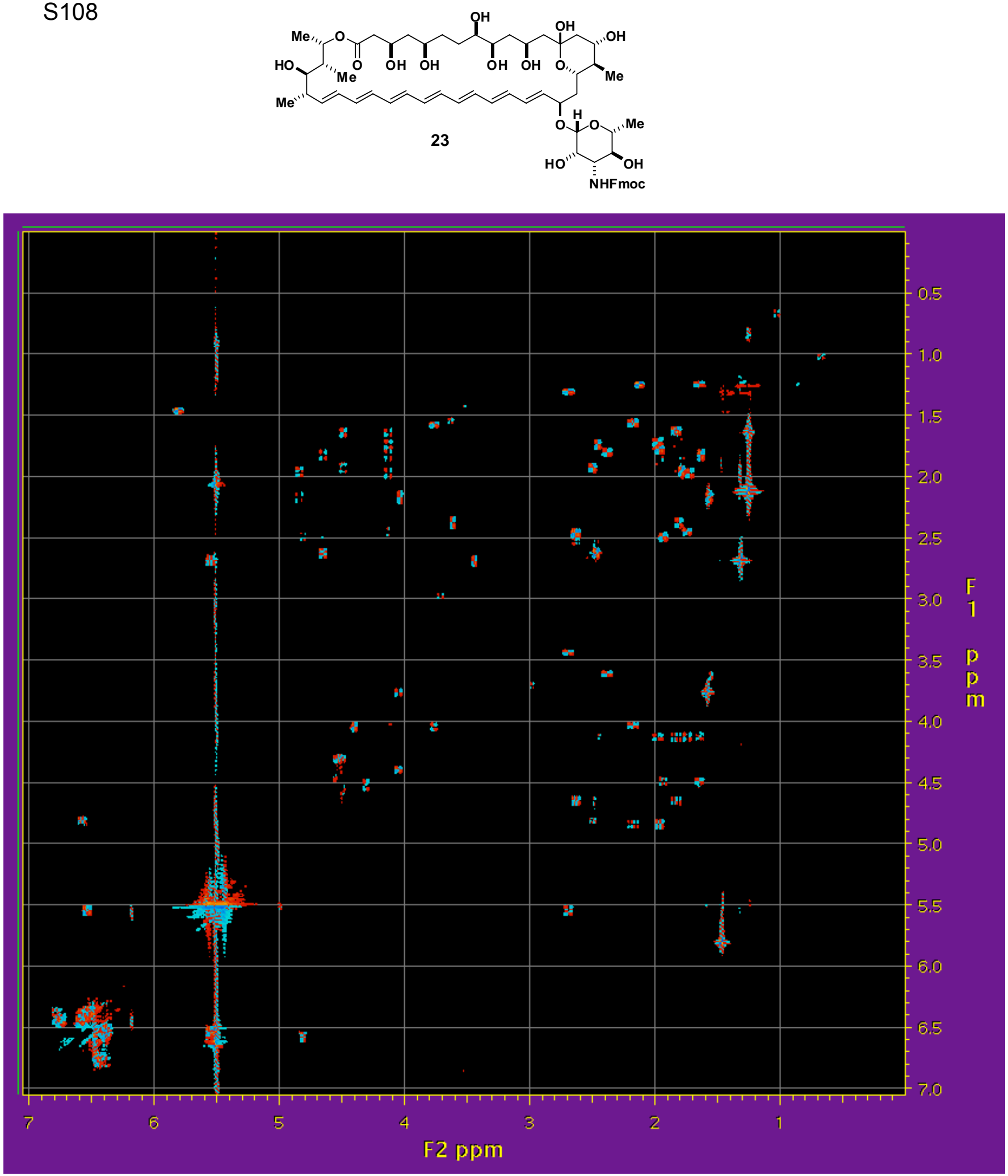

$500 \mathrm{MHz}$ diagonal-suppressed COSYPS spectrum of 23 
S109
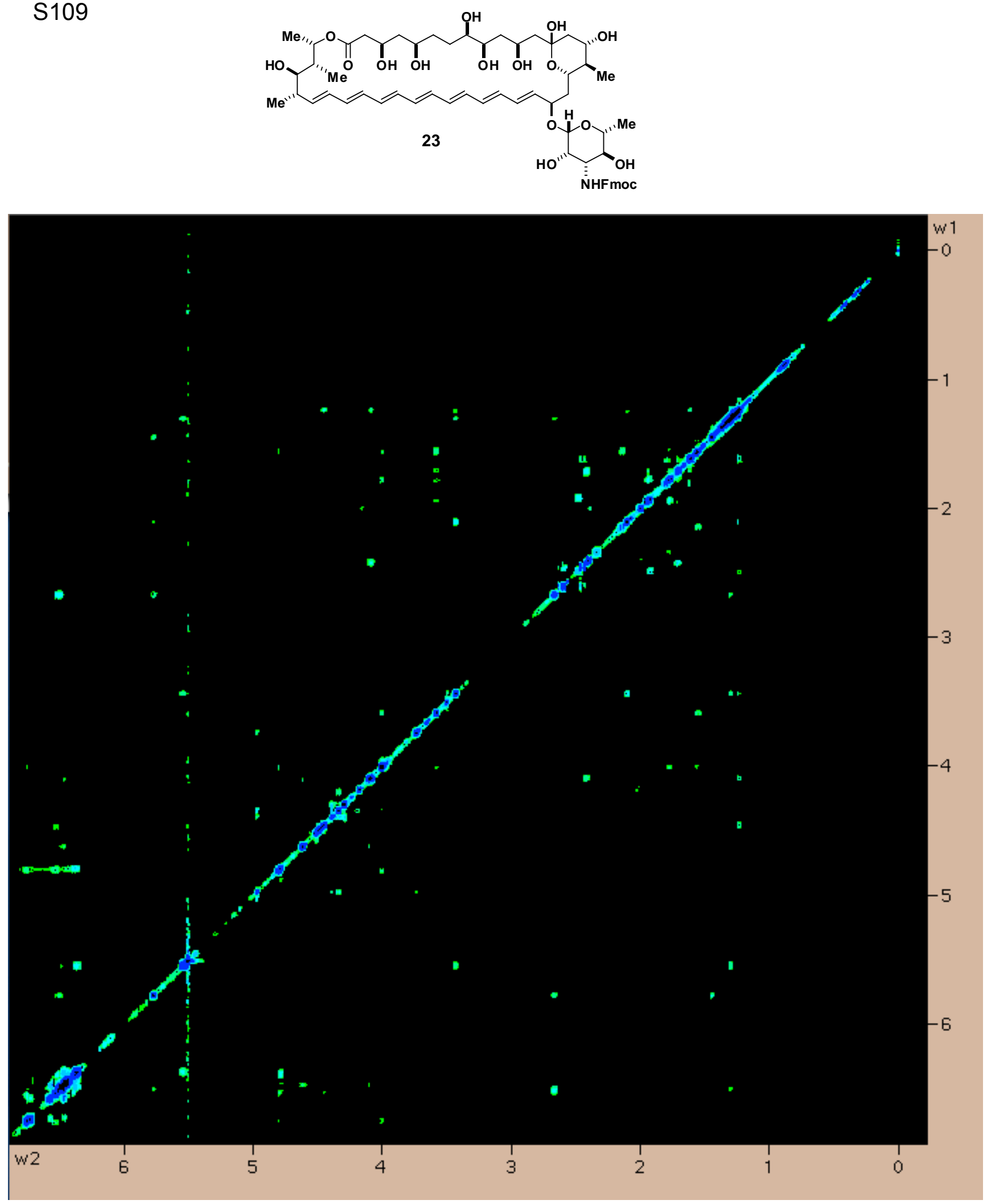

$600 \mathrm{MHz}$ NOESY spectrum of 23 
Data File C: \HPCHEM \I\DATA \TMA \AMBPURE000002.D

Sample Name: AmB

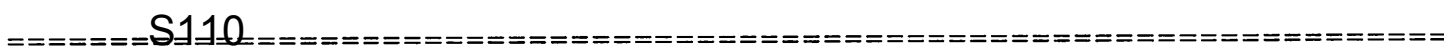

Acq. Operator : TMA

Acq. Instrument : El Chupacabra

Injection Date : 3/16/2007 10:33:32 AM

Acq. Method : $\mathrm{C}: \backslash$

Last changed : $3 / 1$

Analysis Method : C: 1 .

Last changed

Sample Info

$: 7 / 1$

(mor

: Cher

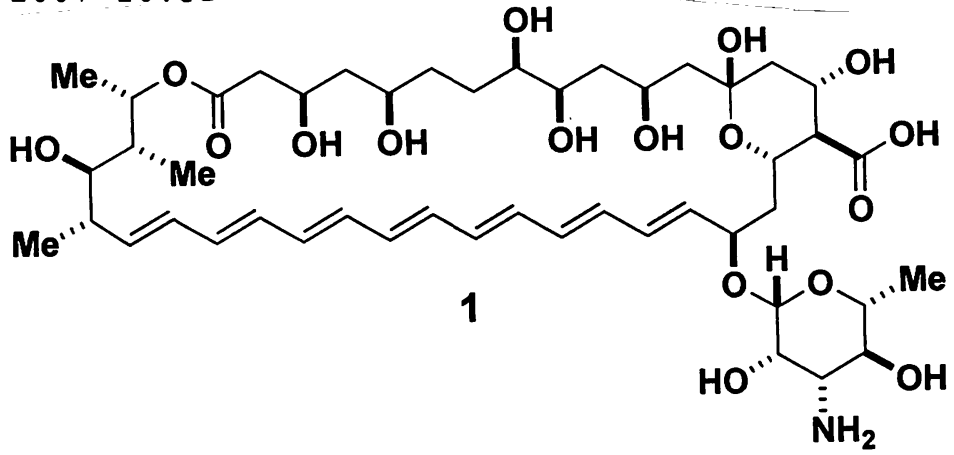

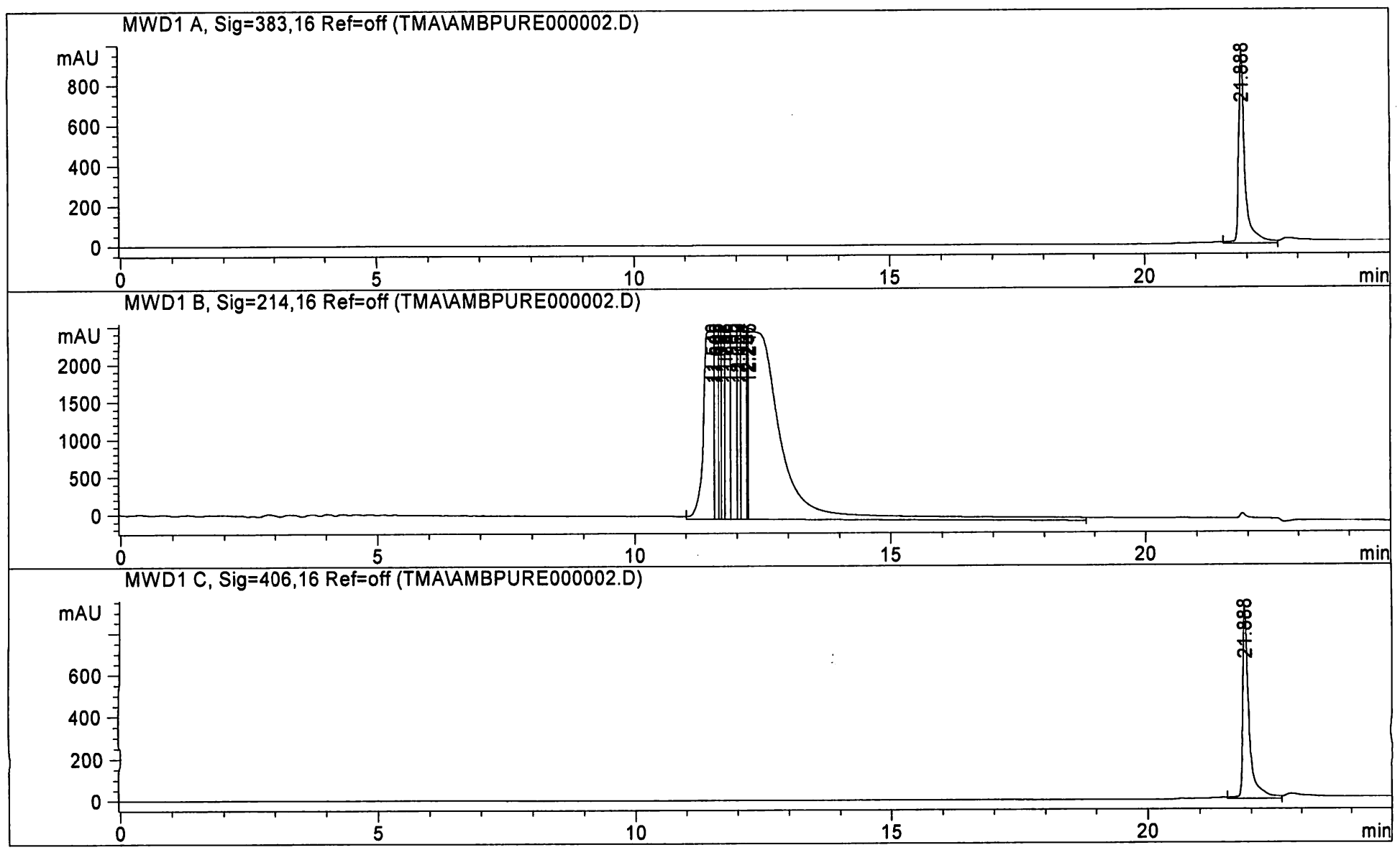

Fraction Information

Fraction collection off

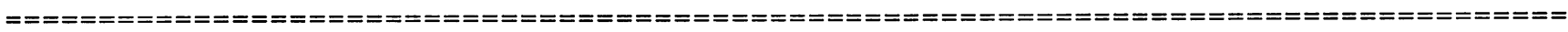

No Fractions found.

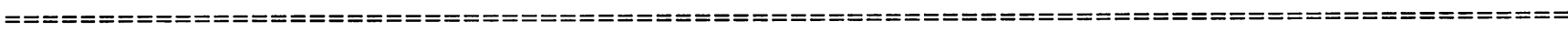


Data File C: $\backslash$ HPCHEM $\backslash 1 \backslash$ DATA $\backslash D A N \backslash H Y B R I D \_F I N A L 008 . D$

= = = = =

Acq. Op£itator : dan

Acq. Instrument : $\mathrm{El} \mathrm{Cr}$

Injection Date : 5/29,

Acq. Method : C: $\backslash \mathrm{H}]$

Last changed : $5 / 28$, (mod:

Analysis Method : $\mathrm{C}: \backslash \mathrm{H}$ :

Last changed : $7 / 19$

Sample Info :

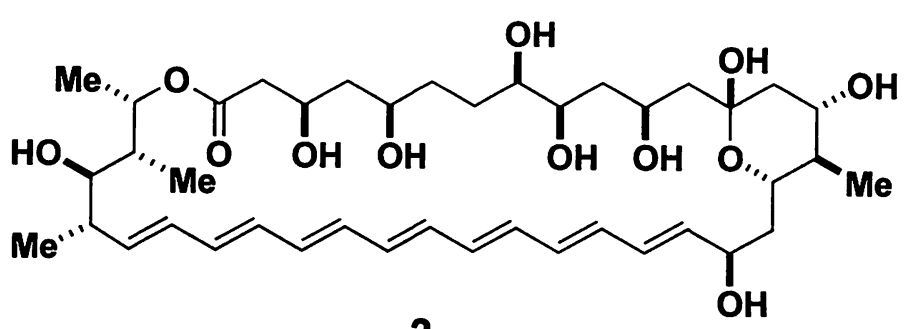

2

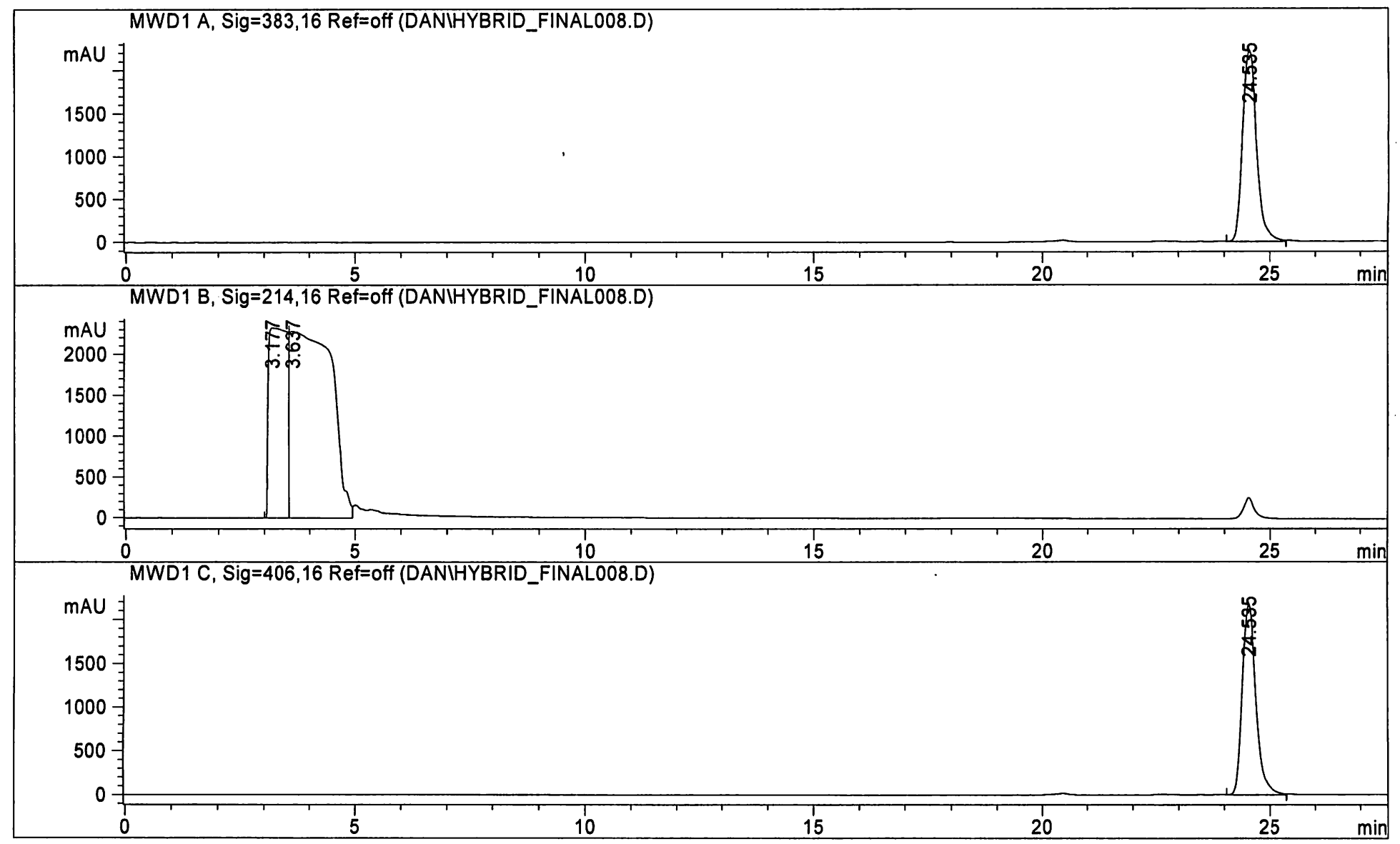

Fraction Information

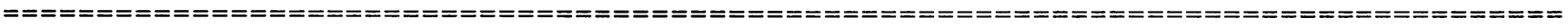

Fraction collection off

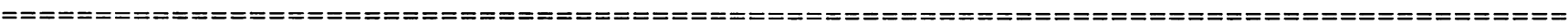

No Fractions found.

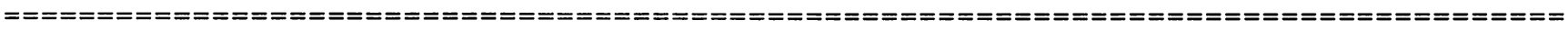




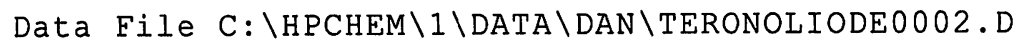

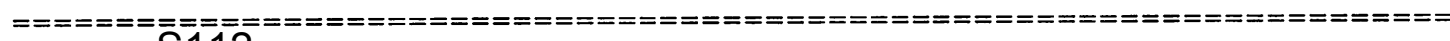

Acq. Op\$raltor : dan

Acq. Instrument : El Chupacabra Location: Vial 1

Injection Date : $3 / 21$.

Acq. Method : $\mathrm{C}: \backslash \mathrm{H}$ :

Last changed : $3 / 20$

Analysis Method : $\mathrm{C}: \backslash \mathrm{H}$

Last changed : $7 / 19$

Sample Info

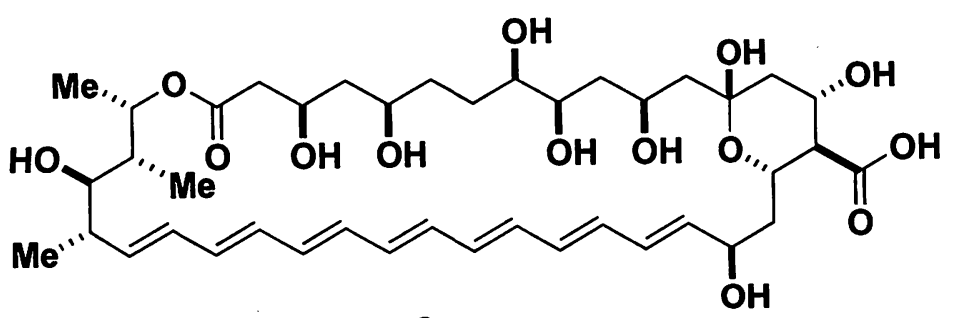

3

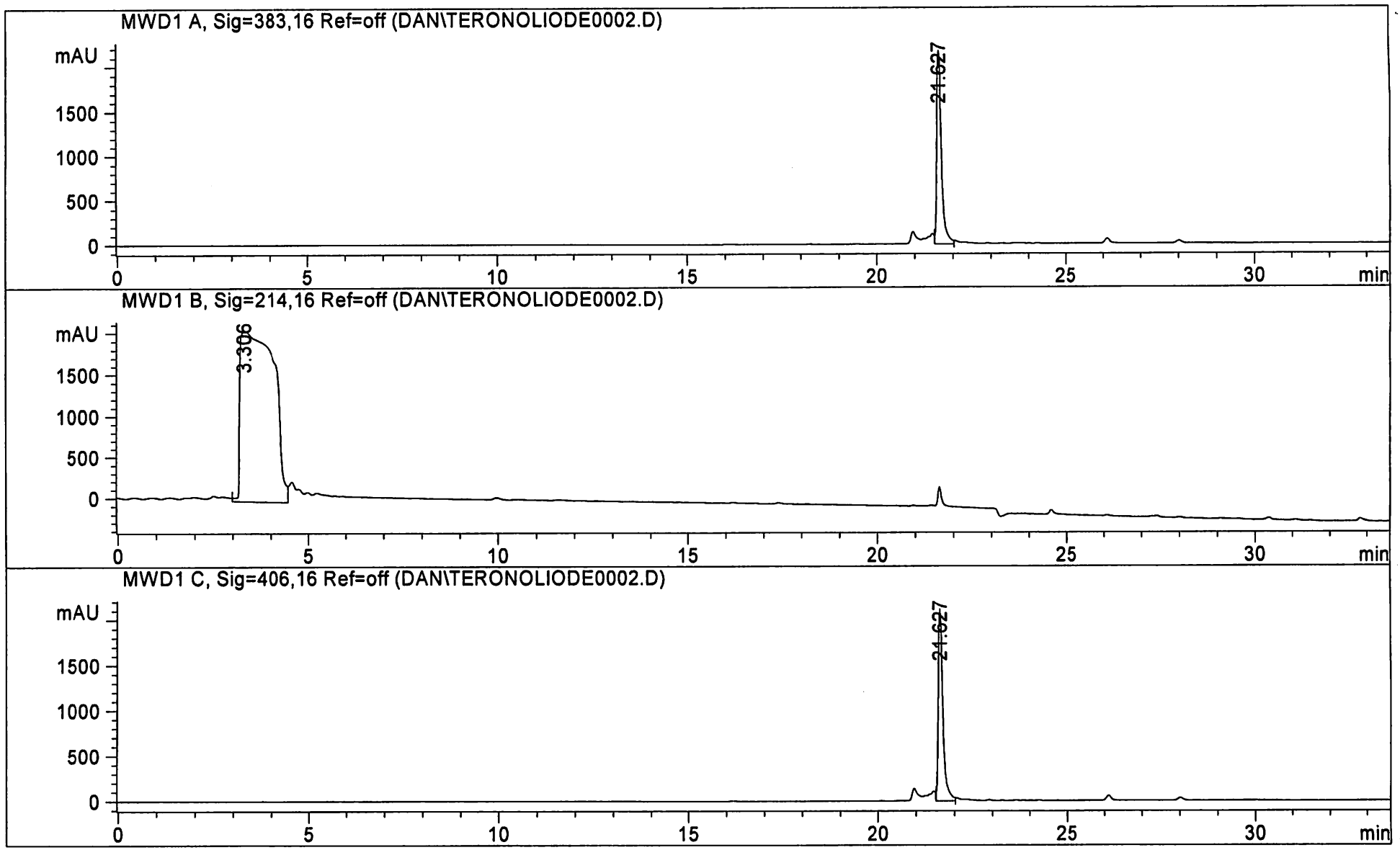

Fraction Information

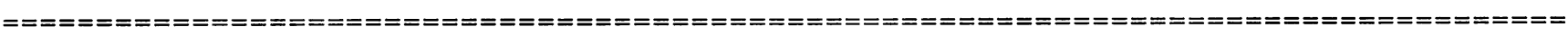

Fraction collection off

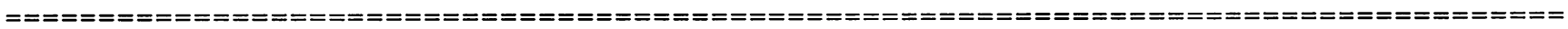

No Fractions found.

e= = = = 


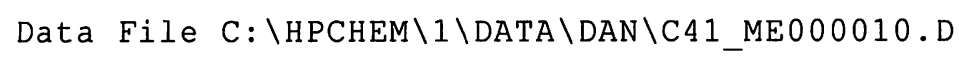

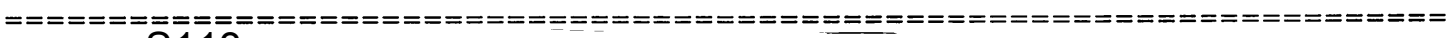
Acq. Op\&11

Acq. Instrument : El $r$

Injection Date

Acq. Method

Last changed

Analysis Method :

Last changed

Sample Info

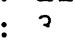

: 2

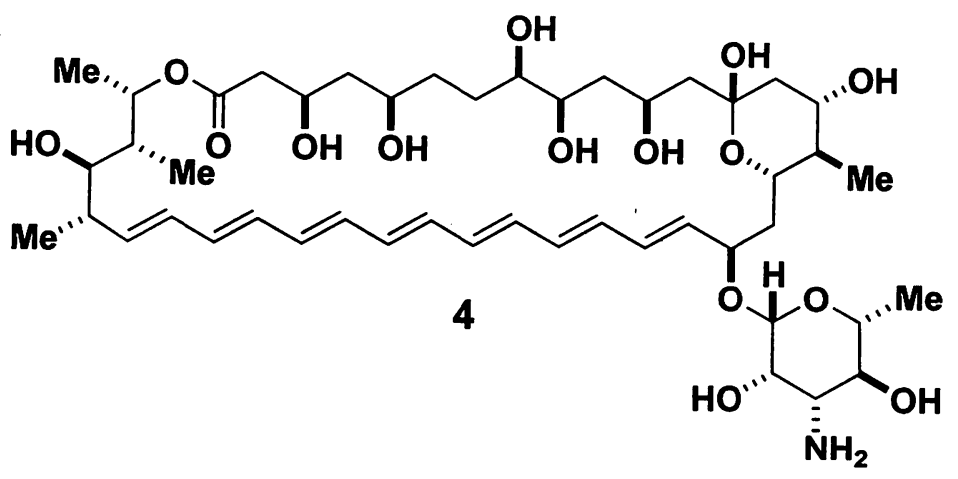

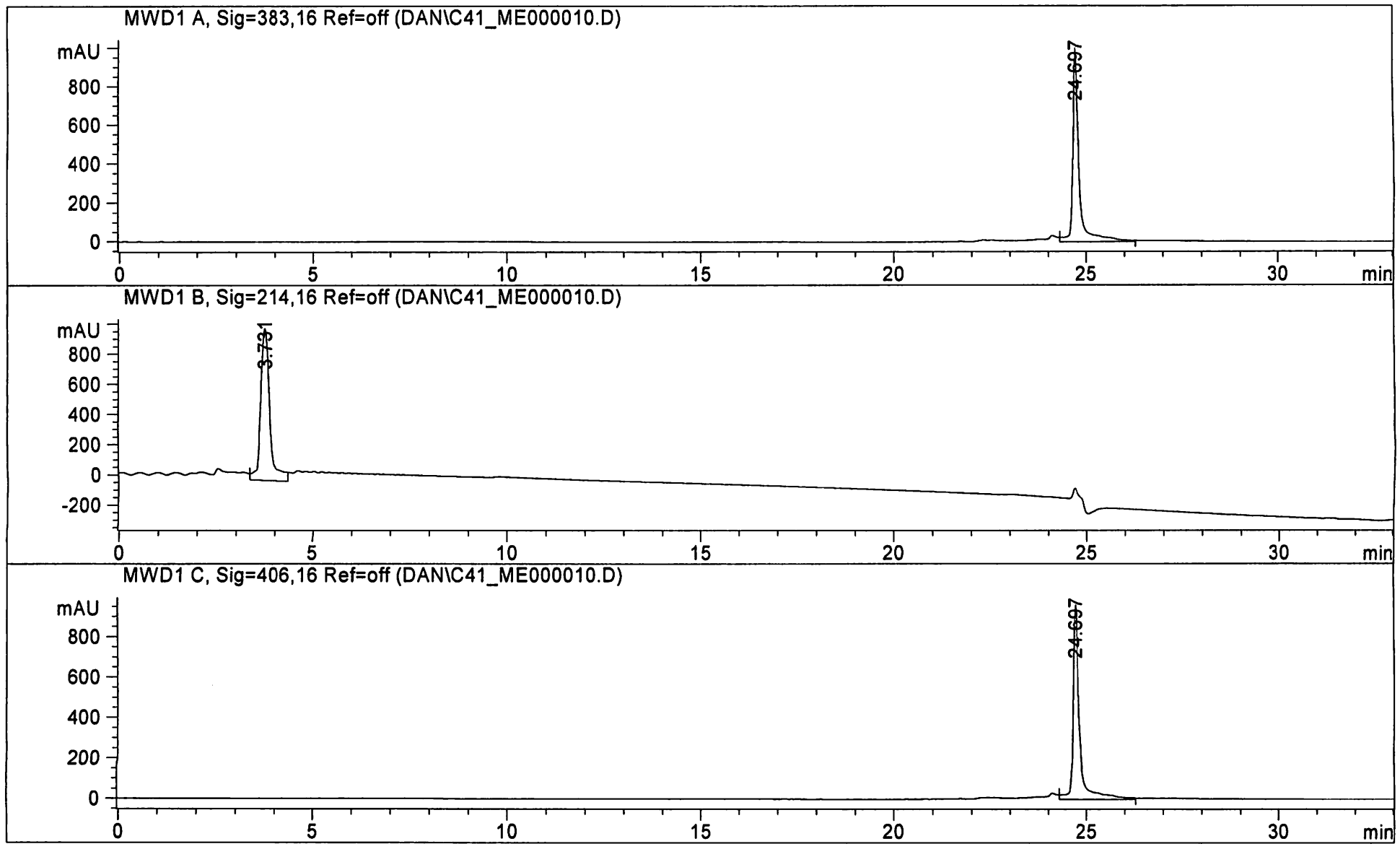

\section{Fraction Information}

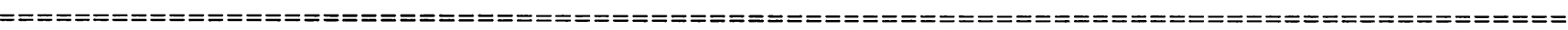
Fraction collection off

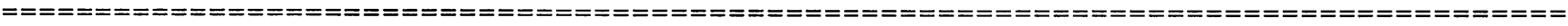
No Fractions found.

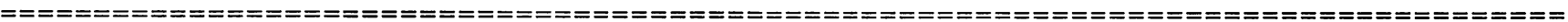

